\title{
Levar a justiça e a cruz aos sertões: os movimentos de ocupação dos sertões do Rio Grande e a formação da freguesia de N. Sra. da Conceição do Bom Sucesso do Rio Pardo na segunda metade do século XVIII'
}

Bringing justice and the cross to the hinterlands: the occupation movements in the hinterlands of Rio Grande and the formation of the parish of N. Sra. da Conceição do Bom Sucesso do Rio Pardo in the second half of the 18th century

https://doi.org/10.1590/1982-02672021v29d le10

\section{RAFAEL AUGUSTO SILVA FERREIRA²}

hitps: / / orcid.org/0000-000 1-5723-4869

Pontifícia Universidade Católica de Campinas / Campinas, SP, Brasil

\section{RENATA BAESSO PEREIRA ${ }^{3}$}

hitps://orcid.org/0000-0003-2690-158X

Pontifícia Universidade Católica de Campinas / Campinas, SP, Brasil

RESUMO: No processo de ocupação da hinterlândia da América portuguesa, os sertões do Rio Grande - localizados entre as capitanias de São Paulo e Minas Gerais e que têm como um de seus limites o curso d'água que lhes empresta o nome - foram redefinidos durante o século XVIII como espaço de disputas entre os governos civis e eclesiásticos de São Paulo, Minas Gerais e Goiás. Este trabalho pretende demonstrar o processo de constituição da rede urbana no território em disputa, onde os núcleos urbanos fundados nos interstícios das capitanias também foram instrumentos para consolidação do território e dos interesses geopolíticos lusos em contraposição aos espanhóis. A rede urbana nesse território é marcada pela presença de quilombos, pelos mecanismos do fisco do ouro e do controle dos caminhos, por meio dos registros, e pela forte

\begin{abstract}
1. Este artigo é resultado de estudos desenvolvidos no grupo de pesquisa "História das cidades: ocupação territorial e ideários urbanos" e de discussões que aconteceram durante o $2^{\circ}$ Congresso Ibero-Americano de História Urbana, na Cidade do México, em 2019, na mesa "Urbanização e conexões macroterritoriais em perspectiva americana e global", coordenada pela Profa. Dra. Beatriz Piccolotto Siqueira Bueno, da Faculdade de Arquitetura e Urbanismo da Universidade de São Paulo (FAU-USP) e pelo Prof. Dr. Rafael de Faria Domingues Moreira, da Universidade Nova de Lisboa. Este trabalho foi realizado com apoio da Coordenação de Aperfeiçoamento de Pessoal de Nível Superior (Capes) sob Código de F i n a n c i a m e n t o 88887.284969/2018-00.

2. Arquiteto e urbanista. Doutorando no Programa de Pós-Graduação em Arquitetura e Urbanismo (POSURB-ARQ, PUC - Campinas). Membro do grupo de pesquisa "História das cidades: ocupação territorial e ideários urbanos" do
\end{abstract}


Centro de Ciências Exatas, Ambientais e de Tecnologia (Ceatec). Bolsista da Coordenação de Aperfeiçoamento de Pessoal de Nível Superior (Capes). E-mail: <rafaelaugustosferreira@gmail.com>.

3. Professora doutora do Programa de Pós-Graduação em Arquitetura e Urbanismo (POSURB-ARQ, PUC - Campinas). Membro do grupo de pesquisa "História das cidades: ocupação territorial e ideários urbanos" do Centro de Ciências Exatas, Ambientais e de Tecnologia (Ceatec). E-mail: <renata.baesso@puc-campinas.edu.br>. presença da Igreja Católica como instrumento de ocupação dos sertões, por intermédio da ereção de capelas e da elevação de freguesias. Nesse contexto, destacamos algumas ações que visavam garantir a posse desse território, além da fundação da freguesia de N. Sra. da Conceição do Bom Sucesso do Rio Pardo (1775), evento importante nas disputas de fronteira e no povoamento desses sertões. Metodologicamente, este trabalho insere-se no campo disciplinar da história da urbanização e mobiliza uma variação de escalas geográficas. As fontes primárias incluem a cartografia histórica e cartas e ofícios dos governos civis e eclesiásticos.

PALAVRAS-CHAVE: Rede urbana. Bispados. Sertões do Rio Grande. Sertão do Rio Pardo. Freguesia de N. Sra. da Conceição do Bom Sucesso do Rio Pardo.

ABSTRACT: In the process of occupying the hinterland of Portuguese America, the hinterlands of Rio Grande - located between the Captaincies of São Paulo and Minas Gerais and bounded by the watercourse that lends its name - were being redefined, during the 18th century, as a space of disputes between the civil and ecclesiastical governments of São Paulo, Minas Gerais and Goiás. This study aims at showing the process of constituting the urban network in the disputed territory, where the urban centers founded on the interstices of the captaincies were also instruments for consolidating the territory and the Portuguese geopolitical interests as opposed to the Spanish interests. The urban network in this territory presents singular characteristics, marked by the presence of quilombos, by the mechanisms of gold taxation and the control of trails by the customs barriers, by the strong presence of the Catholic Church as an instrument of occupation of the hinterlands, by the erection of chapels and the foundation of parishes. In this context, we highlight some actions to assert the possession of this territory in São Paulo and the foundation of the parish of N. Sra. da Conceição do Bom Sucesso in Rio Pardo (1775) as an important event in the border disputes and in the settlement of these hinterlands. Methodologically, this study is classified within the disciplinary field of the History of Urbanization and works with a variation of geographic scales. Primary sources include historical cartography and letters from civil and ecclesiastical governments.

KEYWORDS: Urban network. Bishoprics. Rio Grande hinterland. Rio Pardo hinterland. Parish of N. Sra. da Conceição do Bom Sucesso do Rio Pardo. 
INTRODUÇÃO

No século XVIII, as buscas e descobertas de metais preciosos somadas às disputas para estabelecer os limites entre os domínios coloniais de Portugal e Espanha intensificaram os processos de ocupação da hinterlândia ${ }^{4}$ da América luso-espanhola. Nesse contexto, os sertões do Rio Grande figuraram como um entrave à política de ocupação das terras do interior da colônia portuguesa e foram alvo de disputas entre os governos civis e eclesiásticos de São Paulo, Minas Gerais e Goiás. Este artigo pretende demonstrar o processo de formação da rede urbana nos sertões do Rio Grande por meio do exame do papel desempenhado pelos núcleos de povoamento de diferentes status, civis e religiosos, como arraiais, capelas, freguesias e vilas. Além disso, busca apresentar outras formas de fixação no território, como registros, descobertos e quilombos, que também podem ser lidos em uma perspectiva de conjunto como parte de uma rede urbana mais plural. ${ }^{5}$ Nessa rede urbana, analisamos a fundação da Freguesia de N. Sra. da Conceição do Bom Sucesso do Rio Pardo, em 1775, como um evento significativo na definição das fronteiras das capitanias de Minas Gerais e São Paulo, mas relacionada, também, a conjunturas geopolíticas mais amplas.

recorte espacial do estudo é a rede urbana formada nos sertões confinantes entre as capitanias de São Paulo e Minas Gerais, localizados entre a margem oeste do rio Sapucaí e o Caminho dos Goiases, em uma região que tinha como limites, ao norte, o rio homônimo, na fronteira da Capitania de São Paulo, e à leste os sertões da Comarca do Rio das Mortes, na Capitania de Minas Gerais (Figura 1). Os sertões do Rio Grande são entendidos como a denominação genérica de um espaço ${ }^{6}$ heterogêneo, compreendendo diversos "sertões" onde havia descobertos auríferos e que, a partir de meados do século XVIII, recebeu outras denominações conforme sua ocupação se consolidava: Sertão de São João de Jacuí, Sertão do Desemboque e Sertão do Rio Pardo. No entanto, a indefinição dos limites e as disputas envolvendo a conversão desses sertões em território são suas principais características.

Inconstantes eram também as delimitações de fronteiras de capitanias e suas sobreposições às fronteiras dos bispados. Esses fatores contribuíram para o surgimento de conflitos e contestações sobre a posse de locais de mineração e povoações criadas por ambos os governos. Tais disputas em torno das fronteiras entre as capitanias iniciaram-se nas primeiras décadas do século XVIII, mas foi a partir da década de 1740 que os sertões do Rio Grande se tornaram foco de disputas que somente seriam resolvidas em definitivo no século XX. ${ }^{7}$
4. A palavra hinterlândia é aqui empregada com o sentido de terras interiores, sertão: "[...] em resposta a quatro estímulos interligados - a distribuição de terras; a descoberta de ouro; a necessidade de implantar a lei e a ordem no sertão; e a ameaça pendente dos interesses espanhóis - os portugueses resolveram-se a cobrir a hinterlândia com um sistema de cidades, vilas e povoações organizadas" (DELSON, 1997, p. 14). De acordo com Fonseca (2011), o sertão da América portuguesa pode ser associado a outros contextos geográficos e a outros termos, como binterland $\mathrm{e}$ wilderness na América do Norte. O termo binterland foi em sua origem um conceito colonial que designava as zonas circunvizinhas de uma cidade ou de um porto, podendo até estabelecer uma relação de oposição com toda a costa.

5. A rede urbana pode ser compreendida como um conjunto de pontos com diferentes status, distribuídos hierarquicamente, resultado do processo de urbanização e de formação do território. Na definição de Reis Filho (1968, p. 78), a rede urbana é "o conjunto de respostas às solicitações do processo [de urbanização]", a decorrência direta da política urbanizadora, e que determina "os papéis que os centros urbanos vão desempenhar no sistema" (1968, p. 66). Para Reis Filho (1968), a significação dos núcleos ou de suas partes só pode ser compreendida quando referida ao seu contexto mais amplo, que é a rede. Ao estudar a Capitania de Minas Gerais, Fonseca (2011, p. 557) acrescenta que a rede urbana é composta de "nódulos" hierarquizados: "cidades, vilas (e vilas cabeça de comarca), povoações-sede de julgados e de freguesias, além de uma miríade 
de arraiais que continham apenas uma capela filial".

6. Utilizamos o conceito de "espaço" conforme as definições de Milton Santos (2002, 2004). O espaço é um conjunto indissociável de sistemas de objetos e sistemas de ações, uma forma-conteúdo. O espaço diferencia-se da noção de configuração geográfica ou territorial e se define como o "conjunto formado pelos sistemas naturais existentes em um dado país ou numa dada área e pelos acréscimos que os homens superpuseram a esses sistemas naturais" (SANTOS, 2002, p. 13-14). O espaço nos sertões ora pesquisados é resultado da introdução de meios de ação e práticas sociais da cultura portuguesa, marcado não só pela forte presença da religião católica, mas também das culturas indígena e quilombola. Isso fica evidente, por exemplo, na toponímia da região, nas cerimônias de posse, na instituição de lugares e na simbologia católica.

7. No contexto do Estado Novo, promulgado por Getúlio Vargas em 1934, foi celebrado o convênio entre os estados de Minas Gerais e São Paulo, por meio do decreto $\mathrm{n}^{\circ} 7.168$, de 25 de maio de 1935, que constituía uma comissão para o exame e resolução das divisas estaduais. O término da questão veio com a Lei $n^{\circ} 115 / 1936$ de Minas Gerais, assinada pelo governador mineiro Benedito Valadares Ribeiro, e com a Lei $n^{\circ}$ 2.694/1936, assinada pelo governador paulista Armando de Salles Oliveira, ambas com redação idêntica, celebrando as novas divisas e pondo fim à questão vigente desde o século XVIII.

8. Adotamos o conceito de escalas geográficas conforme Fonseca (2011, p. 42). De acordo com a autora, "a urbanização é um fe-
Embora os documentos demonstrem que esses sertões já eram habitados por gentios e quilombolas, sua ocupação só foi reconhecida pelos governos das capitanias e dos bispados quando novas freguesias e vilas foram criadas. Exemplo desse processo foi o descoberto aurífero de 1765, no sertão do Rio Grande, termo da vila de Jundiaí, em um dos afluentes do rio Pardo, elevado a freguesia de $\mathrm{N}$. Sra. da Conceição do Bom Sucesso do Rio Pardo em 1775, região do atual município paulista de Caconde. Um mapa da capitania de São Paulo de 1773 demonstra a disputa de fronteiras, quando nomeia o "sertão" a oeste do rio Sapucaí como "usurpado da Capitania de Sam Paulo" (Figura 1).

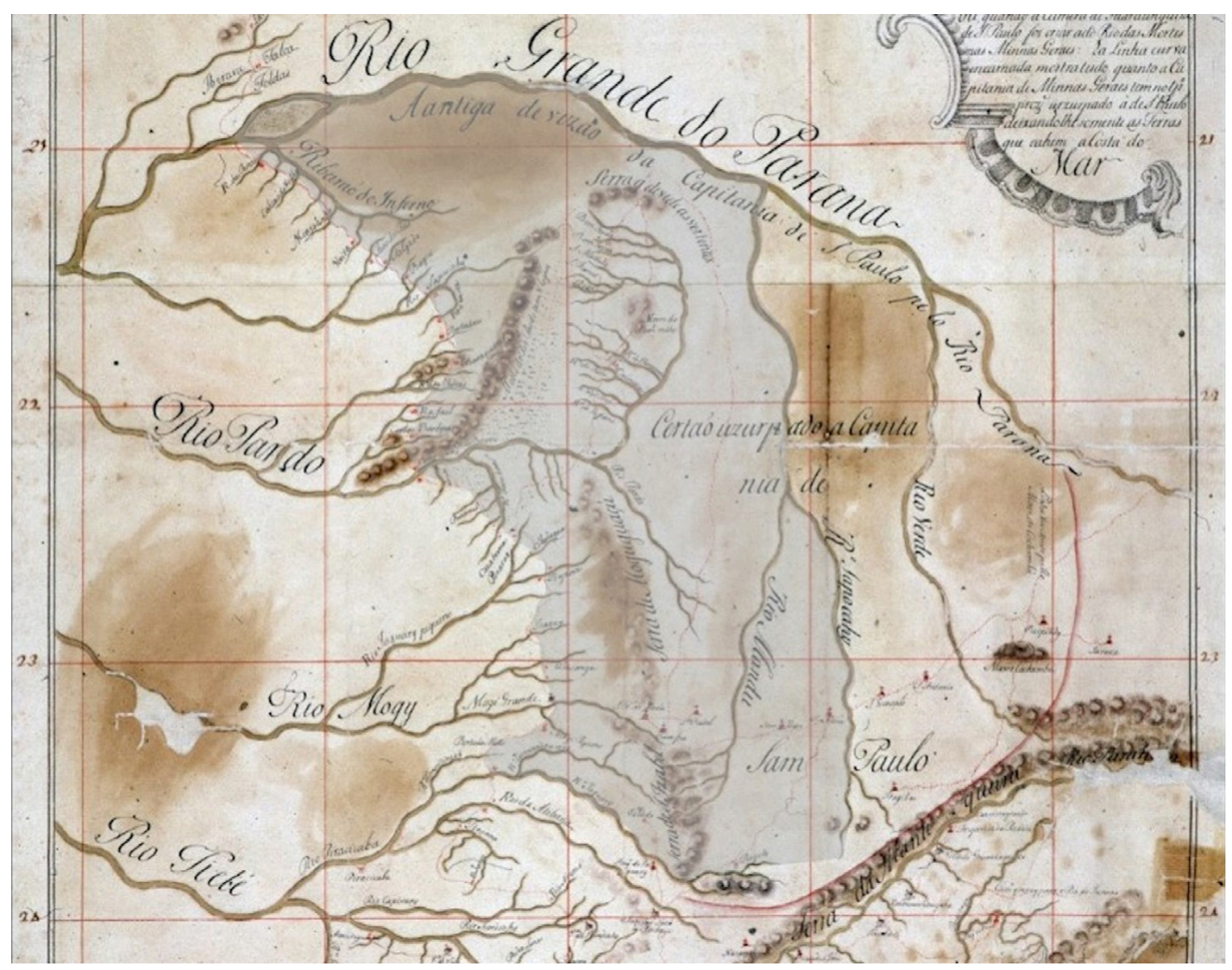

Figura 1 - Trecho do Mappa da Capitania de S. Paulo em que se mostra tudo o que ella tinha antigamente the [sic] o Rio Paraná. Na mancha cinza estão destacados, pelos autores, os sertões confinantes entre as capitanias de São Paulo e Minas Gerais, da porção a oeste do rio Sapucaí até o Caminho dos Goiases, tendo como limite, ao sul, a vila de Jundiaí e, ao norte, o Rio Grande. Fonte: Rede Memória: Coleção Cartográfica e Iconográfica Manuscrita do Arquivo Histórico Ultramarino. Disponível em: <http://bit.ly/3d20joy>. Acesso em: 14 mar. 2020.

Esta pesquisa se insere no campo disciplinar da história da urbanização e trabalha com uma variação de escalas geográficas ${ }^{8}$ como método de análise do processo de ocupação do território. De acordo com Beatriz Piccolotto Siqueira Bueno, a abordagem da história da urbanização permite ampliar o campo de visão para 
"todos os espaços produzidos pela urbanização como processo social" , atentando para a lógica e o papel dos núcleos urbanos no âmbito de um "sistema urbano". 10 Este trabalho articula escalas diferentes e complementares abrangendo desde aquelas das maiores circunscrições administrativas (capitanias, bispados e comarcas) e dos vários sertões, passando pelas escalas tomadas consideradas intermediárias, que correspondem aos termos das vilas e freguesias, até as menores escalas, que se referem às diferentes formas de fixação no território: descobertos, arraiais, povoações, entroncamentos de caminhos e registros. Esse é o modo mais adequado de considerar os ritmos, a dinâmica e a complexidade do processo de urbanização, ${ }^{11}$ no qual vários movimentos ocorreram simultaneamente. Essas escalas estão evidenciadas na documentação coeva - textual e cartográfica - e a alternância nas suas análises produz uma narrativa na qual o fio condutor é justamente o movimento, rompendo com a narrativa linear e demonstrando a interdependência entre as escalas de análise.

Os movimentos de ocupação dos sertões e de sua progressiva incorporação ao território colonial português nos revelam as nuances de um projeto de reorganização territorial empreendido pelos governadores das capitanias no decorrer do século XVIII, além de uma conjuntura, sobretudo a partir da segunda metade daquele século, relacionada às disputas entre as coroas ibéricas pela ocupação da hinterlândia da América luso-espanhola. Segundo Derntl, "uma motivação fundamental para o impulso à urbanização na segunda metade do século XVIII foi atender a novas exigências que se apresentaram no processo de demarcação de fronteiras com os espanhóis". ${ }^{12}$ Para a autora, durante o reinado de D. José I (1750-1777), D. Maria I (1777-1792) e na regência de D. João (1792-1816) "buscou-se ampliar e reforçar as estruturas administrativas, judiciárias e militares na Colônia". ${ }^{13}$ A política do Marquês de Pombal, ministro de D. José I, redefiniu a hierarquia entre as capitanias e a revisão das áreas por elas abrangidas. A elevação de vilas tornou-se um instrumento para a afirmação da soberania portuguesa. ${ }^{14}$

António Manuel Hespanha apresenta a tese da inexistência de um "modelo ou estratégia gerais para a expansão portuguesa". ${ }^{15} \mathrm{Em}$ vez disso, segundo o autor, existem alguns tópicos usados para justificar a expansão colonial, como a expansão da fé. Mas, mesmo esses tópicos não eram harmônicos e, frequentemente, levavam a políticas contraditórias ou até opostas. ${ }^{16} \bigcirc$ autor destaca que parece não ter havido uma estratégia sistemática que abrangesse todo o Império, pelo menos até meados do século XVIII:

é mesmo só com Pombal e com os ministros ilustrados de D. Maria que planos particulares e gerais de uma organização política do Ultramar ganham forma, primeiro em relatórios, consultas e diretórios, depois em projetos concretos de reformas territoriais, econômicas, nômeno que se produz em diversos níveis; ao mudarmos a distância focal, o objetivo não é 'ampliar (ou diminuir) o tamanho do objeto no visor, mas modificar a sua forma e a sua trama'. De fato, ao passarmos da pequena à grande escala (no sentido geográfico do termo), nosso objeto assume diferentes formas: de um conjunto de pontos indistintos, distribuídos numa vasta superfície, ele se transforma, primeiramente, numa rede hierarquizada (formada de nódulos com diferentes capacidades de polarização) e, em seguida, em espaços intraurbanos de diferentes extensões e densidades. A variação das escalas de análise constitui, assim, um modo de ter presentes a complexidade e a dinâmica do processo de urbanização".

9. Bueno (2012, p. 19). Segundo a autora, "à compreensão da cidade e do território como artefato social, soma-se a visão sistêmica que leva em conta atores, processos, dinâmicas e fluxos, redes de relações sociais, redes urbanas e suas configurações no espaço em perspectiva histórica" (BUENO, 2012, p. 19).

10. Ibid., p. 19.

11. Fonseca, op. cit., p. 4145.

12. Derntl (2013, p. 45).

13. Ibid., p. 48.

14. Ibid., p. 49

15. Hespanha (2001, p. 167).

16. Hespanha (2001, p. 129), ao negar a tese de centralidade do Império português e de um projeto de colonização, afirma que, "pelo contrário, os interesses mercantis, o proselitismo religioso e, mais tarde, os intuitos povoadores ou de drenagem demográfica 
constituíam, sucessivamente, a justificação da colonização do Brasil".

17. Hespanha (2012, p. 28).

18. Segundo Hespanha (2001, p. 167), "a sobrevivência dessa imagem pode ser explicada por uma interpretação ingênua - ainda que ideologicamente significativa - das instituições históricas, fundada em preconceitos enraizados acerca da relação colonial. Do ponto de vista do colonizador, a imagem de um Império centralizado era a única que fazia suficientemente jus ao gênio colonizador da metrópole".

19. Hespanha (2001, 2012). Para uma análise detida nos conceitos do autor, ver o capítulo de Hespanha (2001, p. 165-188)

20. Hespanha (2012, p. 15 , grifo nosso).

21. Ibid., p. 16.

22. Hespanha (2001).

23. Ibid., p. 177. urbanísticas e de governo, que visam vários pontos e situações do império, desde Macau ao Brasil, passando por Angola. ${ }^{17}$

Hespanha questionou a tese de centralidade do Império português ${ }^{18} \mathrm{em}$ relação a suas colônias e desenvolveu o conceito de que a estrutura administrativa do Império era centrífuga. ${ }^{19}$ Para o autor, o sistema político de poder nas colônias era ainda mais pluralista do que o do reino,

estirado por forças centrífugas ainda mais potentes, alongados pelas distâncias - que não eram só a de cruzar mares, mas também de vencer sertões -, onde essa mesma distância parecia fazer alongar a sombra do rei na sombra parasitariamente engordada dos seus funcionários. ${ }^{20}$

Para Hespanha, a centralidade do Império português se dissolvia em uma multiplicidade de relações contraditórias e polos, nos quais a Coroa ocupava lugares e hierarquias frequentemente insignificantes. Em contrapartida, "tanto se alevantavam poderes locais altaneiros, como as tais sombras dos 'funcionários' régios se alongavam em dimensões autônomas, cobrindo e dando legitimidade prática a toda sorte de iniciativas e ousadias". ${ }^{21}$ Nesse sentido, são também relevantes as ações de agentes autônomos que buscavam enriquecer, obtendo privilégios de controle de caminhos ou passagens de rios, datas de mineração ou sesmarias.

Segundo Hespanha, os poderes dentro da hierarquia políitca colonial gozavam de grande autonomia, inclusive os vice-reis, governadores, donatários, governadores locais e juízes. ${ }^{22}$ De acordo com o autor, embora os governadores-gerais, a partir de 1549, usufruíssem de supremacia sobre os donatários e governadores das capitanias, essa dependência ficava bastante limitada pelo fato de todos deverem obediência aos secretários de Estado em Lisboa. ${ }^{23}$ Esse arranjo administrativo acabava por criar um espaço de poder autônomo efetivo na colônia, que influenciou diretamente a política aplicada nos sertões limítrofes das capitanias de São Paulo e Minas Gerais, além de promover desavenças e disputas entre seus respectivos governadores. A documentação textual analisada neste artigo busca lançar luz no desencontro da política dos governadores como chave de leitura para uma série de conflitos oriundos da ocupação dos sertões do Rio Grande, na segunda metade do século XVIII.

Se não se pode afirmar a existência de um projeto para a colonização portuguesa pensado enquanto plano prévio direcionado a uma execução, é lícito afirmar, no entanto, a ideia de que a política urbanizadora da Coroa se revela nos diversos movimentos de ocupação dos sertões: campanhas de extinção de quilombos, instituição de capelas e criação de freguesias, criação de postos de 
julgados em arraiais e a posse civil e eclesiástica de descobertos auríferos. Como bem afirma Derntl, a política urbanizadora desse período é mais fruto de um processo desenvolvido num contexto de conflitos do que "o produto de um projeto predelineado por autoridades metropolitanas ou alheio a realidades do lugar". ${ }^{24}$

Laura de Mello e Souza tece uma crítica sobre algumas teses de Hespanha, destacando certo descuido do autor em relação à especificidade do Império português na América, que o levaria a generalizações baseadas em situações próprias do Oriente. ${ }^{25}$ Para Souza, também é um problema o fato de o autor desconsiderar que "ao fim, e ao cabo, tudo se fazia em nome do Rei e de Portugal", ${ }^{26}$ argumentando que, embora houvesse uma autonomia de poder, distinta da atual, nem por isso havia ausência de Estado, mas sim um Estado "em que as racionalidades eram outras". ${ }^{27}$ Apesar da crítica de Laura de Mello e Souza, ${ }^{28}$ segundo a qual os pressupostos teóricos do autor funcionariam bem para o estudo do Seiscentos português, mas deixariam a desejar quando aplicados ao Setecentos em geral e ao Brasil, parece-nos lícito dialogar com o autor para compreender melhor a política lusa adotada na colônia e o relacionamento entre os governadores das capitanias, considerando, contudo, que a partir de meados do XVIII há uma evidente mudança na política que já vinha sendo adotada para a colônia.

$\bigcirc$ objetivo deste trabalho é revisitar ${ }^{29}$ os eventos que tiveram como palco a região dos sertões do Rio Grande, oferecendo novas interpretações por meio de uma visão de conjunto articulada à conjuntura da segunda metade do século XVIII. As fontes primárias analisadas incluem documentação textual e cartográfica produzida pelas capitanias e pelos bispados de São Paulo e Minas Gerais. Os documentos textuais $^{30}$ são compostos por cartas e ofícios trocados entre os governadores, a Coroa e os agentes do poder civil e eclesiástico da região. As fontes cartográficas abrangem os mapas das capitanias produzidos no século XVIII e mapas dos sertões. Os documentos textuais e cartográficos nos revelam, de maneira contínua e sistemática, os discursos de soberania e domínio territoriais, de posse da terra e de suas riquezas minerais, dos descaminhos do ouro, bem como as práticas cotidianas ligadas ao exercício da fé católica. $\bigcirc$ conflito, portanto, é parte intrínseca desse território e pode-se mesmo afirmar que desse conflito nasceu boa parte das ações empreendidas na fundação de arraiais, capelas, freguesias e vilas.

Oestado da arte sobre o tema deste estudo é vasto em contribuições mais recentes. Apoiados nos estudos que privilegiam a dimensão espacial dos processos históricos e que buscam ampliar o conceito de urbano para "†odo e qualquer vestígio de localidade indicativa da presença humana irradiada de demandas urbanas", ${ }^{31}$ buscamos incluir na rede urbana outras formas de fixação que, malgrado estejam "aquém do estereótipo citadino", 32 deveriam ser levadas
24. Derntl (2012, p. 128).

25. Souza (2006, p. 50-51).

26. Ibid., p. 51 .

27. Ibid., p. 51

28. Cf. Hespanha (2012).

29. Cf. Campanhole (1979), que analisou as disputas pelo povoamento e pelos descobertos auríferos na região da Freguesia de $\mathrm{N}$. Sra. da Conceição do Bom Sucesso do Rio Pardo, embora sob uma perspectiva diferente da deste artigo. Cf. também Derntl (2013, p. 127), acerca das "disputas nos confins", que traz à tona as negociações em torno da definição de limites entre as capitanias de São Paulo e Minas Gerais e o foco de disputa nos "novos descobertos do Rio Pardo" (DERNTL, 2013, p. 131), e Bellotto (2007, p. 82), sobre os "novos descobertos de N. Sr. ${ }^{a}$ da Conceição do Rio Pardo". Ambas as autoras procuram situar as disputas locais dentro da política empreendida pelo governador Morgado de Mateus. Este artigo retoma as questões dos autores citados, revisitando alguns eventos e trazendo outros à tona por meio da documentação primária.

30. Buscamos conservar a grafia original dos documentos primários utilizados neste artigo.

31. Bueno (2016, p. 826) Na linha de uma "arqueologia da paisagem", que busca identificar como funcionavam as comunicações na colônia e suas atividades de comércio, o abastecimento e a circulação de indivíduos no território, além dos caminhos e dos papéis cumpridos pelas várias formas de fixação supracitadas e que nos dão a dimensão do urbano, destacamos trabalhos mais recentes sob orientação da Profa. Dra. 
Beatriz Piccolotto Siqueira Bueno (FAU-USP). Nesse grupo, que compartilha metodologias em comum, destacamos os estudos de Esdras Arraes (2017) e Nathália Diniz (2015), sobre os sertões do Norte, e de Nádia Mendes de Moura (2018), sobre a formação da Capitania de Goiás.

32. Bueno (2016, p. 834).

33. Ibid., p. 834 .

34. Bueno (2017, p. 243).

35. Tese defendida em novembro de 2001 na École des Hautes Études en Sciences Sociales, em Paris, com o título: Pouvoirs, villes e territoires: gênese et représentations des espaçes urbains le Minas Gerais (Brésil, XVIII e-debut du $X I X$ e siècle) (FONSECA, 2001), (publicada como livro no Brasil em 2011. Cf. Fonseca (2011).

36. Citamos a tese de doutorado de Cícero Ferraz Cruz (2016), sobre a formação da vila de Campanha da Princesa e seu termo, além da dissertação de Carolina Farnetani de Almeida (2019), investigação centrada na formação da rede urbana a oeste do rio Sapucaí e de quatro freguesias - Jacuí (1762), Cabo Verde (1765), Ouro Fino (1748) e Santana do Sapucaí (1748) -, cujo recorte temporal se inicia em meados do século XVIII e se estende até 1833 , quando se desmembra a Comarca do Rio das Mortes, na Capitania de Minas Gerais.

37. Marcia Amantino (2001, 2003, 2006, 2014). Nos trabalhos citados a autora desenvolve temas como a ocupação dos sertões a oeste de Minas Gerais, as guerras indígenas, a escravidão e a presença quilombola nos confins da capitania. Sobre esse último tema, cf. Florentino e Amantino (2012). em consideração por sua capacidade de "irradiação de urbanidade" ${ }^{33}$ em escala regional. Essa mudança de concepção foi explicitada em um artigo recente de Beatriz Bueno, que nos esclarece que

estudos recentes permitem entender a rede urbana na sua conotação mais ampla, nela incluindo-se pousos, bairros rurais, fazendas, feiras, passagens, registros e demais pontos nodais relacionados às cidades, vilas, capelas, freguesias, julgados e aldeamentos missioneiros. [...] Esses estudos permitem ainda alargar o conceito de núcleo urbano propriamente dito, ao demonstrar que lhe orbitavam um rosário de bairros rurais, fazendas e sítios que alimentavam mercados distantes. Nesse sentido, achamos pertinente incluir no horizonte das questões citadinas pontos de economia que extrapolavam a lógica da subsistência, dando-thes visibilidade por estarem imantados a circuitos urbanos e que, em constelação, configuravam territorialidades entretecidas por vivências cotidianas. ${ }^{34}$

É por meio dessa chave de leitura que buscamos analisar o papel desempenhado pelos descobertos auríferos, registros, guardas militares, passagens de rios, entroncamentos de caminhos, bem como pela rede de quilombos do território estudado, demonstrando que eram parte de uma rede urbana mais plural.

Desde a pesquisa de Cláudia Damasceno Fonseca, que apresentou uma visão de conjunto da Capitania de Minas Gerais, ${ }^{35}$ estudos recentes avançaram na análise da rede urbana nas Minas com foco na relação com a Capitania de São Paulo. ${ }^{36}$ Os sertões entre as capitanias de Minas Gerais, São Paulo e Goiás têm sido estudados por pesquisadores atentos em identificar nuances sobre sua ocupação e oferecer novas interpretações dos processos históricos. Nessa seara encontram-se os trabalhos de Márcia Amantino, ${ }^{37}$ Marcel Mano, ${ }^{38}$ Angelo Carrara ${ }^{39}$ e Francisco Eduardo de Andrade, ${ }^{40}$ que orbitam em torno dos temas: sertões do oeste de Minas, conflitos de fronteiras, escravidão e quilombos, populações indígenas, instituição de capelas e formação da rede urbana.

Outros trabalhos pioneiros já exploraram questões relacionadas à urbanização do território paulista e à ocupação do sertão do rio Pardo, como a obra de Carlos Bacellar e de Lucila Reis Brioschi. ${ }^{41}$ Em sua dissertação, Dirceu Piccinato Junior ${ }^{42}$ pesquisou a apropriação do solo no nordeste paulista, estudando a formação de patrimônios laicos e religiosos no sertão do rio Pardo, entre 1800 e 1930. Também sobre a rede urbana paulista, destacamos a pesquisa de Jéssica de Almeida Polito sobre a formação do binômio das Mogis (Mogi Mirim e Mogi Guaçu), relacionada à estruturação do leste paulista. ${ }^{43}$ 


\section{PAISAGENS TOPONIIMICAS E O LÉXICO DA OCUPAÇÃO DOS SERTÕES}

conceito de "paisagem toponímica", presente no trabalho de Iris Kantor, ${ }^{44}$ esclarece que os nomes atribuídos aos lugares revelam o caráter de sua ocupação, servindo também a interesses geopolíticos. A autora nos lembra que "desde a antiguidade, os cerimoniais de posse incluíam o estabelecimento de uma nova toponímia a cada nova conquista", 45 o que, no mundo ibérico, estava associado à prática da religião e ao calendário hagiográfico. ${ }^{46}$ Para Esdras Arraes, "a paisagem, sob o ponto de vista toponímico, é configurada e codificada por uma série de localidades nomeadas por sua significância social". ${ }^{47}$

Destacamos a articulação entre os vários sertões que compõem a região de estudo deste trabalho e a mudança em sua toponímia: sertão do Rio Grande, nos limites das capitanias de São Paulo e Minas Gerais; sertão do Rio das Mortes, no termo da vila mineira de São João del Rei; 48 sertão do Campo Grande, zona situada entre as nascentes do Rio São Francisco e o curso do Rio Paranaíba, ${ }^{49}$ tendo como limite ao sul o Rio Grande e, a leste, a capitania de Goiás; e o sertão do rio Pardo, denominação posterior de uma parte do sertão do Rio Grande, quando da fundação da Freguesia de Nossa Sra. da Conceição do Bom Sucesso do Rio Pardo e da formação de sua rede urbana, na fronteira com Minas Gerais. $\bigcirc$ sertão do rio Pardo estendia-se do rio que the dá o nome até o Rio Grande, ${ }^{50}$ sendo uma região extensa e heterogênea. A toponímia de diversos pontos nodais da rede incorporou também a onomástica sacra e as línguas nativas indígenas e dos quilombolas: "51 "Santana do Sapucaí", "Cabo Verde", "Jacuí", "Caconde", "Zundú", "Dumbá", "Muzambo", entre vários outros. Neste trabalho busca-se tornar evidente os diversos movimentos e projetos que participaram, de modo concomitante e sucessivo, na ocupação dos sertões do Rio Grande e na sua conversão em território colonial. No período analisado, a toponímia revela as marcas dessa ocupação. ${ }^{52}$

Na documentação coeva, o termo "sertão" está ligado, durante todo o período colonial, à conquista e ao estabelecimento de povoações em locais incultos. "Sertão" designa o "interior desconhecido, selvagem e mítico da colônia", considerado como um "dado preexistente à colonização". 53 Para Cláudia Damasceno Fonseca, os núcleos de povoamento de Minas Gerais, quando abordados na escala da capitania, aparecem como a imagem de uma constelação. Segundo a autora, o pano de fundo para a primeira constelação de arraiais mineiros era o sertão, "que foi se transformando em território à medida que alguns destes pontos se diferenciaram dos demais, tornando-se centros irradiadores do poder civil e religioso" ${ }^{54} \bigcirc$ conceito de território evoca, portanto, um contínuo movimento de enraizamento de estruturas de poder em sertões nos quais
38. Mano (2015).

39. Angelo Carrara (2007).

40. Andrade (2007, 2008, 2011).

41. Bacellar e Brioschi (1999) e Brioschi (1995).

42. Piccinato Junior (2012). O autor dialoga com autores já consagrados que versam sobre o processo de urbanização no sertão do rio Pardo, definindo sua ocupação a partir da abertura do Caminho dos Goiases, no início do século XVIII, e posteriormente com a chegada dos entrantes mineiros.

43. Polito (2013). A autora parte dos relatos de viajantes e naturalistas no século XIX e espacializa uma rede urbana composta de pousos, caminhos e patrimônios religiosos em mapas-base atuais. Demonstra o papel das freguesias de Mogi Guaçu e Mogi Mirim na estruturação da rede urbana paulista a partir das dinâmicas de fixação no Caminho dos Goiases.

44. Kantor (2009).

45. Ibid., p. 40.

46. Kantor (2009, p. 42) acrescenta que, "entre os ibéricos, a homenagem a santos e mártires cristãos era uma prática comum, associando o calendário hagiográfico com as datas das "descobertas" ou da realização da primeira missa. A concessão do Padroado Régio - direito régio de controlar os rendimentos eclesiásticos e de promover a cristianização do Novo Mundo - fez com que as coroas ibéricas estimulassem a memória dos santos e mártires católicos."

47. Arraes, op. cit., p. 72.

48. A vila de São João del Rei foi criada em 1713, na 
localidade antes conhecida como o "arraial do Rio das Mortes”. Somente em 1798 foi criada uma nova vila na comarca do Rio das Mortes: Campanha da Princesa.

49. Cf. Fonseca, op. cit., p. 120.

50. Cf. Piccinato Junior, $o p$. cit.

51. Agradecemos ao Prof. Dr. Rafael Moreira (Universidade Nova de Lisboa) pelos comentários feitos durante a apresentação do trabalho "Nos sertões do Rio Grande: disputas entre capitanias e bispados na ocupação da hinterlândia”, no $2^{\circ}$ Congresso Ibero-Americano de História Urbana, na Cidade do México, em 2019. As discussões na mesa sobre as possíveis origens da toponímia dessa região de estudo nos fizeram repensar a importância das raízes africanas e indígenas para a historiografia do povoamento dos sertões. Cf. Ferreira, Pereira e Almeida (2019).

52. Como bem observou Esdras Arraes (2017, p. 132) em relação aos "sertões do norte", o "movimento" traçou um dos fundamentos da construção das paisagens nos sertões e estruturou um sistema de marcas tangíveis cristalizadas em caminhos terrestres, fluviais, pousos, passagens de rios e nos assentamentos humanos de diferentes status, que se revelam na toponímia. Cf. Arraes (2016).

53. Fonseca, op. cit., p. 51. No dicionário do padre Raphael Bluteau, o sertão é definido como toda "Região apartada do mar, \& por todas as partes metidas entre terras" Bluteau (1712-1728, v. 7, p. 613).

54. Fonseca, op. cit., p. 557. 55. Cruz, op. cit., p. 29. anteriormente o Estado português não se fazia presente. Constituir um território significa tomar posse e, nesse sentido, o território colonial coincide com a jurisdição de um governo. Cícero Ferraz Cruz também nos lembra que a "definição de um território sempre passou pela delimitação e representação de uma determinada área por determinado grupo". ${ }^{55}$ Assim, o território não é um dado existente, tampouco é natural e espontâneo, 56 mas é uma "categoria histórica, construída socialmente". ${ }^{57}$ Nesta pesquisa, o conceito de território é tomado como a linha abstrata da jurisdição do Estado colonial português, que se enraíza em topônimos e em diferentes pontos irradiadores do poder civil e religioso. ${ }^{58} \mathrm{Na}$ colônia, entre as instituições das quais emanava o poder luso estão as capitanias, comarcas, vilas, freguesias e os julgados, cada qual contendo um território de dimensões e natureza próprias. Isso também se aplica aos bispados e comarcas eclesiásticas, circunscrições que se sobrepunham àquelas de caráter civil.

Márcia Amantino observa que em todas as definições do termo "sertão" há sempre a oposição entre o litoral e o interior, entre povoado e despovoado. ${ }^{59}$ Quando o termo é empregado em documentos do século XVIII, transparece a ideia de regiões que não passaram por processos civilizatórios, passíveis de serem ocupadas pelo colonizador que subjuga o indígena e o quilombola. Sertão e conflito frequentemente se confundem: o sertão como lugar da revolta e do descontrole, da barbárie dos povos não civilizados, de ausência da civilização trazida pelo colonizador e não no sentido de inexistência de ocupação humana. ${ }^{60}$

Em trabalhos recentes, ${ }^{61}$ o "sertão" passa a ser interpretado como um espaço plural, originário das diversas interações entre o homem e o mundo que o envolve. ${ }^{62}$ Esdras Arraes destaca o sertão em oposição ao corriqueiro sentido depreciativo, qualificando-o como espaço positivo e heterogêneo. ${ }^{63}$ Isso leva a considerar o papel das populações indígenas de várias etnias e dos quilombolas como fundamental no processo de construção do território.

A transformação na toponímia dos sertões é um elemento-chave para compreender o processo de ocupação e construção do território. Essa toponímia vai sendo modificada para dar lugar a nomes que revelam a incorporação desses territórios à rede urbana, como "descoberto", 64 "povoação"65 e "campanha".66 $\bigcirc$ léxico utilizado na documentação da época indica os ritmos da ocupação e da colonização, remetendo-se às divisões oficiais feitas pelos poderes civis e eclesiásticos, e às práticas dos habitantes, que tinham sua maneira de vivenciar e representar os diferentes lugares aos quais pertenciam. ${ }^{67}$

Os sertões foram progressivamente ressignificados ao sabor do avanço de sua ocupação, que dispôs de diversos mecanismos para assegurar sua posse: fundação de capelas, instituição de patrimônios religiosos, criação de freguesias, 
instituição de vilas e julgados, organização de campanhas militares para dizimar quilombos e subjugar populações indígenas, criação de destacamentos militares e registros nos principais caminhos, além da concessão de sesmarias e do avanço da fronteira agropastoril em direção aos sertões meridionais das capitanias de Minas Gerais e São Paulo - movimentos que ocorreram de forma simultânea e interdependente. Exemplo dessa interdependência são as campanhas militares organizadas pelos governadores de Minas Gerais para destruir quilombos, que contavam com a presença de representantes do Bispado de Mariana, encarregados de tomar posse de arraiais e freguesias que anteriormente foram instituídas pelo Bispado de São Paulo. Além disso, a criação de freguesias e vilas e a instituição de julgados nos sertões nos limites das capitanias estavam vinculadas às disputas para estabelecer os limites entre as coroas ibéricas.

\section{A ABERTURA DE CAMINHOS, A CRIAÇÃO DAS CAPITANIAS, BISPADOS E COMARCAS, E OS PRIMEIROS CONFLITOS DE FRONTEIRAS ENTRE MINAS GERAIS E SÃO PAULO}

No período analisado, a política de colonização das coroas ibéricas e a expansão da cristandade na América se revelam na criação de estruturas na macroescala: as capitanias, as comarcas e os bispados. Transparecem os conflitos entre os governadores das capitanias de São Paulo e Minas Gerais e, do mesmo modo, entre os bispados, pela ocupação dos sertões do Rio Grande. Como explicitado anteriormente, grande parte desses conflitos se explica pela própria natureza da estrutura político-administrativa da colônia, assente sobre a autonomia de poderes de diversos funcionários régios. Um argumento que se busca demonstrar é que o caráter de imprecisão dos limites entre os termos dos Concelhos das Câmaras de Minas Gerais e de São Paulo, em meados do século XVIII, produziu litígios nessa zona de fronteira.

Os litígios de fronteira entre São Paulo e Minas Gerais já foram objeto de estudos anteriores, 68 e não constitui objetivo deste artigo retomar essa discussão. Contudo, deve-se ressaltar alguns pontos que se relacionam com nossa perspectiva de análise, com os núcleos urbanos estudados e com a dinâmica de formação dos caminhos, conforme o recorte espacial deste trabalho. Em 1709, depois dos primeiros descobrimentos auríferos, a Coroa decidiu criar a capitania de São Paulo e Minas do Ouro, por meio da reincorporação dos territórios das antigas capitanias de São Vicente e Santo Amaro. 69 De acordo com Derntl, essa passou a ser a maior capitania da colônia, abrangendo territórios do Centro-Oeste e do Sudeste até a Colônia de Sacramento, excluindo-se o Rio de Janeiro e a vila de Santos. ${ }^{70}$ Em
56. Cf. Bueno (2009).

57. Ibid., p. 251. No dicionário de Raphael Bluteau, território é "o espaço de terra, nos contornos \& jurisdição de huã cidade" (BLUTEAU, 1728, v. 8, p. 128).

58. Cf. Fonseca, op. cit., p. 557.

59. Para a autora, "este último par de ideias remete a um outro ponto de discussão. A noção de que existiria uma área povoada, civilizada e controlada, contrária a uma outra, selvagem, bárbara e despovoada de cristãos" (AMANTINO, 2003, p. 84).

60. Id., 2014, p. 94.

61. Cf. Diniz (2013, 2015), Arraes (2017) e Moura (2018).

62. Arraes (2017, p. 49).

63. Ibid., p. 64.

64. "Descoberto" é a expressão usada para descrever um pequeno agrupamento que se forma junto a um ribeirão de onde era extraído o ouro, por exemplo o "Descoberto do Sapucaí" e o "Descoberto do Rio Pardo", e os sertões adjacentes ao mesmo descoberto. De acordo com Senna (1937, p. 276), muitas localidades na zona aurífera em Minas Gerais receberam essa denominação "porque o termo descoberto [...], conforme o Regimento das minas, era empregado para designar a achada de ouro, onde não existisse concessão ou cata aberta”.

65. A palavra povoação é um termo genérico que poderia se referir a todos os tipos de aglomerações, inclusive vilas e cidades. $O$ termo era correntemente usado para designar um agrupamento humano formado sem status de fregue- 
sia ou vila. Também era empregado quando se referia ao núcleo urbano de uma freguesia, vila ou cidade e não ao conjunto de seu território. Cf. Fonseca, op. cit.

66. O termo "campanha" substitui, algumas vezes, o termo "sertão", por se tratar de uma região de povoamento situada em campos. Mas também pode adquirir uma conotação militar, aproximando-se do termo "conquista", a exemplo das "conquistas e campanhas do Campo Grande”, como era empregado nos casos de conflito com populações preexistentes (índios ou quilombolas) (CRUZ, 2016, p. 40-41).

67. Fonseca, op. cit., p. 74

68. Cf. Salgado e Pereira (2017a), Ferreira (2017), Ferreira e Pereira (2017), Pereira e Ferreira (2018), e Almeida, Ferreira e Pereira (2019).

69. Cf. Salgado e Pereira, op. cit., p. 219.

70. Derntl (2013, p. 69).

71. Ibid., p. 69.

72. Bueno (2009, p. 272).

73. Segundo Salgado e Pereira (2017a, p. 222), "a partir de 1714, a Capitania de São Paulo e Minas do Ouro Fica então com 4 comarcas: São Paulo, Vila Rica, Rio das Velhas e Rio das Mortes. Só em 1720 é que a comarca do Rio das Velhas foi desmembrada para se criar a quinta comarca, a do Serro Frio, cuja sede era a Vila do Príncipe".

74. A extensão do termo da Vila de São João del Rei coincidia, teoricamente, com os limites da comarca do Rio das Mortes e, ao sul, com os da própria capitania de Minas Gerais. Teoricamente, pois essas unidades não se encontravam bem delimitadas (FONSECA,
171 1, a vila de São Paulo foi elevada à condição de cidade, uma medida para reintegrar os paulistas nos planos da Coroa. ${ }^{71}$ Objetivando controlar a região das minas de Cataguases, a Coroa criou, entre 1711 e 1718, oito novas vilas no território que depois seria chamado de Minas Gerais: Sabará, N. Sra. do Carmo (Mariana) e Vila Rica, em 171 1; São João del Rey, em 1712; Vila do Príncipe (Serro Frio) e Vila Nova da Rainha do Caeté, em 1714; Vila Nova do Infante (Pitangui), em 1715; e São José del Rey (Tiradentes), em 1718.72

De 1709 a 1714, o imenso território da capitania ficou sob a jurisdição da comarca de São Paulo, criada em 1700. Em 1714, com o objetivo de aprimorar o controle desse território, o governador da capitania de São Paulo e Minas do Ouro, Dom Brás Baltazar, cria três novas comarcas: comarca do Rio das Velhas, comarca de Ouro Preto e comarca do Rio das Mortes, cujas sedes situavam-se respectivamente nos conselhos municipais das Vilas de Sabará, Vila Rica e São João del-Rey. ${ }^{73}$ Os termos das comarcas coincidiam com os termos das vilas, e estes, por sua vez, constituíam causas de lifígios frequentes. $\bigcirc$ primeiro conflito entre comarcas na região de estudo se deu entre a comarca do Rio das Mortes, por meio da vila de São João del Rei (1712), e a comarca de São Paulo, pela vila de Guaratinguetá (1 651 1).74 A vila de Guaratinguetá não se conformou com a divisa que afetava seu termo e, em 1714, mudou os marcos de divisão entre as comarcas, iniciando os conflitos territoriais. ${ }^{75}$ A separação das capitanias de São Paulo e Minas Gerais ocorreu em 2 de dezembro de 1720, data do alvará expedido pelo rei de Portugal. Assim, os conflitos pelas delimitações de suas fronteiras são na verdade uma continuação das disputas pelos termos das comarcas e das vilas, em litígio desde 1714 .

Para Fonseca, a criação das comarcas, maiores circunscrições civis da capitania, era parte do projeto metropolitano de controle da arrecadação dos impostos (notadamente o quinto do ouro). Segundo esse raciocínio, cabia determinar a quais comarcas pertenciam os núcleos mineradores, mais do que os limites da comarca em si. A situação de "fronteira aberta" era uma condição usual nas comarcas: seus contornos eram definidos à medida que os confins eram ocupados e surgiam conflitos locais de jurisdição. ${ }^{76}$

No contexto dos eventos e conflitos descritos anteriormente, dois caminhos foram fundamentais na estruturação da rede urbana na fronteira entre Minas Gerais e São Paulo: o dos Goiases e o de Fernão Dias. ${ }^{77} \bigcirc$ Caminho dos Goiases ou Caminho do Anhanguera foi aberto nas primeiras décadas do século XVIII78 e foi o principal eixo de penetração nos sertões do centro-oeste do território colonial. ${ }^{79} \mathrm{~A}$ partir desse caminho principal estruturam-se caminhos tributários, que passaram a garantir os fluxos de pessoas e mercadorias para uma região até então de contornos imprecisos, habitada por gentios e quilombolas, em direção aos sertões da capitania de Minas Gerais e ao 
Caminho de Fernão Dias. ${ }^{80} \bigcirc$ Caminho dos Goiases foi o eixo da fundação de vários núcleos urbanos, nascidos de pousos que modelavam as viagens diárias e estabeleciam lugares de produção e comércio de diversos gêneros.

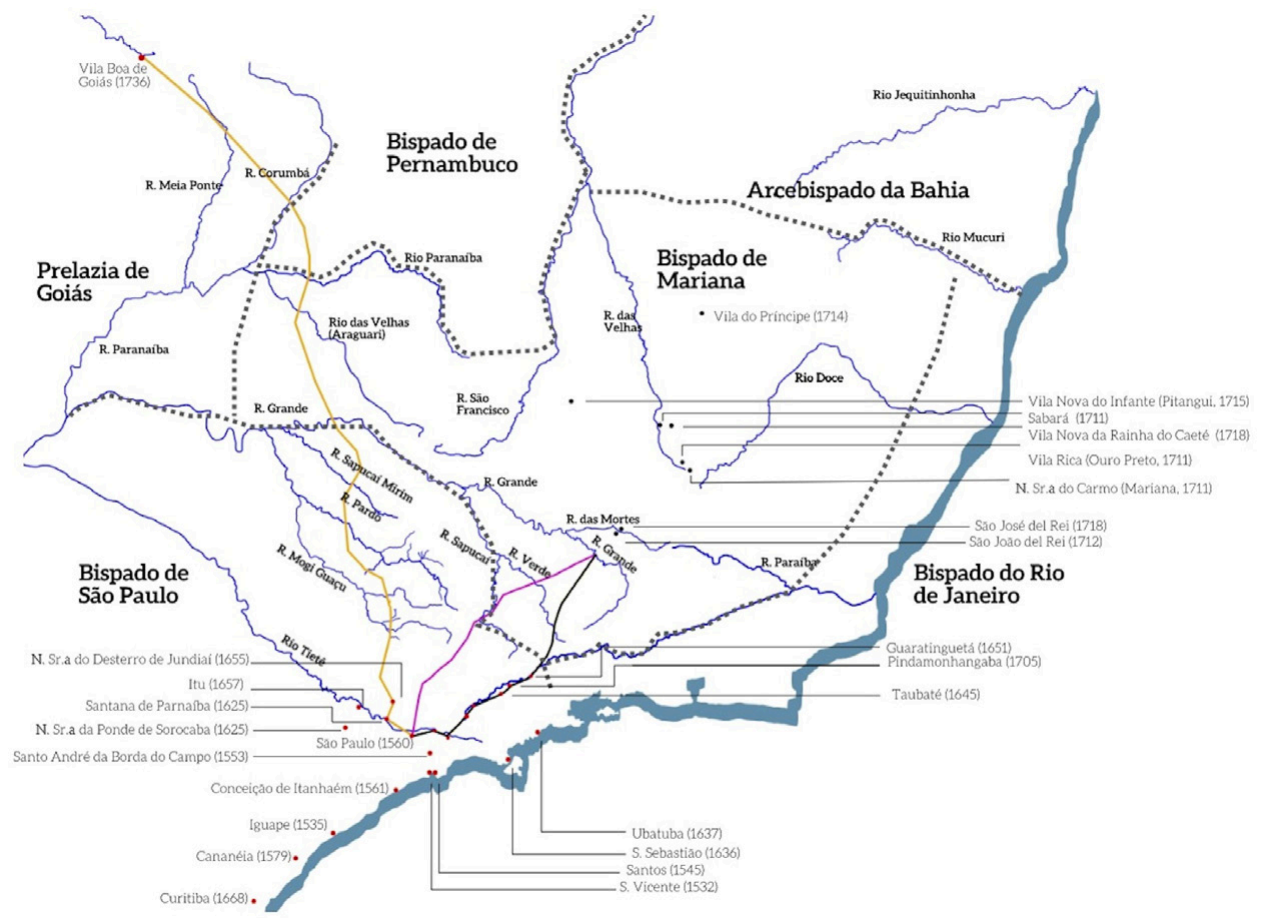

Figura 2 - Mapa demonstrando a divisão dos bispados de São Paulo e Mariana e da prelazia de Goiás, criados em 1745, em relação aos iá existentes bispado de Pernambuco e arcebispado de São Salvador (Bahia). As vilas paulistas (em vermelho) e mineiras (em preto) fundadas até 1745 estão destacadas, além da Vila Boa de Goiás (1736), fundada por paulistas em uma região que pertencia à capitania de São Paulo. Estão assinalados o Caminho dos Goiases (amarelo), o Caminho de Fernão Dias (roxo) e o Caminho Velho de São Paulo (em preto). Fonte: Elaborado pelos autores a partir de dados de Bueno (2009) e Fonseca (201 1); IBGE (2009).

A criação dos Bispados de Mariana e de São Paulo pode ser vista como um evento relacionado às disputas entre as coroas ibéricas pela ocupação do interior da América luso-espanhola. ${ }^{81}$ Segundo Gouvêa, a melhor demarcação das fronteiras luso-brasileiras também serviu de cenário para redefinir mecanismos de governo mais efetivos da região centro-sul do Brasil, num "contexto de progressiva transformação econômica" 82 no século XVIII, ligada à extração de ouro. A autora acrescenta que um primeiro quadro de transformações pode ser observado na forma como estavam demarcadas as fronteiras eclesiásticas. ${ }^{83}$ Conforme a bula pontifícia motu próprio Candor lucis aeternae, de 6 de dezembro de 1745, o Papa Bento XIV deu permissão para o rei D. João V instituir as dioceses de Mariana e de São Paulo, além das prelazias de Cuiabá (Mato Grosso) e de Goiás (Figura 2). $\bigcirc$
2011, p. 270). A definição dos limites em 1714, por uma comissão formada por representantes de ambas as capitanias, marcou o início dos conflitos de fronteiras.

75. Cf. Salgado e Pereira, op. cit., p. 222-223.

76. Fonseca, op. cit., p. 143.

77. Sobre esse tema, ver os trabalhos de Almeida (2019) e de Almeida e Pereira (2018).

78. Segundo Reis Filho, as primeiras expedições da família Bueno ocorreram entre 1673 e 1682 , na mesma época da grande bandeira de Fernão Dias Pais Leme, que teve início em 1674 com destino aos sertões de Cataguases em Minas, antes mesmo da criação dessa capitania (REIS FILHO, 2014).

79. O Caminho dos Goiases partia de Santana de Parnaíba em direção a Jundiaí - vila criada em 1655 - cruzando os rios Atibaia, Jaguari e Mogi, seguindo para Mogi Mirim (freguesia criada em 1751) e Mogi Guaçu (freguesia de N. Sra. da Conceição de Mogi dos Campos, criada em 1740), ambas pertencentes ao termo da vila de Jundiaí. Depois, seguia a norte até o pouso de Casa Branca (onde foi criada a freguesia de Casa Branca, em 1814). Depois de Casa Branca, o caminho se bifurcava: uma parte cruzava os rios Pardo e Sapucaí, seguindo para a região dos futuros municípios de Cajuru, Batatais e Franca, até ultrapassar o Rio Grande, passando depois os rios das Velhas, Paranaíba, Corumbá, Meia Ponte e Claro, em direção às minas de Goiás; a outra dirigia-se para a capitania de Minas Gerais (separada de São Paulo em 1722), apresentando variações em direção à freguesia de Caconde (fundada em 1775). Sobre a formação do 
Caminho dos Goiases, cf. Reis Filho (2014).

80. O Caminho de Fernão Dias nasceu a partir das incursões de Fernão Dias Pais Leme, em 1674, e de D. Rodrigo de Castelo Branco, em 1681. Segundo Cruz (2010, p. 20), "o caminho de Fernão Dias partia de São Paulo em direção a Atibaia, passava por Bragança Paulista e pelo registro de Jaguari, na altura de Camanducaia, seguia ao norte passando pela serra de Araquamaba (atual Canguava), pelo Rio do Peixe, pelo topônimo Três Irmãos, pelo povoado de Mandu (atual Pouso Alegre) e rio homônimo e seguia até o povoado de Santana do Sapucaí (atual Silvanópolis). Dali, em direção nordeste, transpunha-se o rio Sapucaí em local chamado passagem do Sapocaí (antiga grafia) chegando-se a São Gonçalo e depois a Campanha do Rio Verde. De Campanha seguia-se, novamente, em direção nordeste passando pelos rios São Bento, Verde (em local denominado Ponte do Rio Verde), do Peixe, Angaí, e Capivari, chegando-se ao local denominado Curralinho (não encontrada correspondência em mapas atuais), de onde se encontrava com o caminho Velho na passagem do Rio Grande". O Caminho de Fernão Dias também apresentava variações que atingiam as minas em Goiás.

81. Na prática, o objetivo de criar essas circunscrições não era apenas melhorar a administração eclesiástica na colônia portuguesa, mas relacionava-se, sobretudo, a interesses de natureza geopolítica, uma vez que os territórios em questão estavam além da linha de Tordesilhas. A criação das dioceses e prelazias, em 1745, representou uma "sanção transcendente do limite das novas dioceses deveria se conformar às fronteiras das capitanias do Rio de Janeiro e de São Paulo e pelas antigas divisas do bispado Fluminense com os da Bahia e de Pernambuco, ${ }^{84}$ fato que gerou problemas pois os limites das capitanias ainda não estavam bem definidos e eram objeto de disputas desde a década de 1720. A bula determinava, como divisa das novas prelazias de Goiás e Cuiabá com a Diocese de São Paulo, o Rio Grande, "por este mesmo grande rio, estendendo-se até onde chegam os domínios do Rei de Portugal". ${ }^{85}$ Já o bispado de Mariana faria divisa com os bispados de São Paulo, com a prelazia de Goiás, com o arcebispado de São Salvador e com o bispado de Pernambuco, estes dois últimos já existentes. ${ }^{86}$ Buscando demonstrar espacialmente os limites das circunscrições eclesiásticas criadas em 1745, foi elaborado o mapa da Figura 2.

\section{ECCE CRUCEM DOMINI: AS CERIMÔNIAS DE POSSE DOS ARRAIAIS, A INSTITUIÇÃO DE JULGADOS E A EXTINÇÃO DE QUILOMBOS}

A criação dos julgados, as campanhas de combate e extinção dos quilombos promovidas pelos governadores e a posse de descobertos e de paróquias anteriormente instituídas pelo bispado de São Paulo fazem parte da estratégia de expansão territorial e se relacionam com a política tributária que vigorou na capitania de Minas Gerais, entre 1735 e $1750 .{ }^{87}$ A cobrança do imposto da capitação tornou necessário incorporar novas terras à capitania de Minas Gerais, aumentando o rol dos contribuintes para os cofres reais. Nos sertões do Campo Grande, da Farinha Podre (atual triângulo mineiro) e no sertão do Rio Grande, a criação de postos de julgados ${ }^{88}$ foi o meio adotado pelas capitanias de Minas Gerais e de Goiás para exercer controle sobre o território, onde não convinha criar concelhos de vilas.

Iremos explorar em maiores detalhes os descobertos auríferos nos sertões do Rio Grande, analisando três autos de posse feitos pela capitania e pelo bispado de São Paulo: Descoberto de Jacuí (1755), Descoberto do Desemboque (1761) e Descoberto de N. Sra. da Conceição (1765). As pesquisas de Cícero Ferraz Cruz ${ }^{89}$ Carolina Farnetani de Almeida ${ }^{90}$ e de Ivone Salgado e Renata Baesso Pereira ${ }^{91}$ já demonstraram a formação dos primeiros núcleos urbanos a oeste do rio Sapucaí - Santana do Sapucaí, em 1745 latual Silvianópolis, Minas Gerais), Ouro Fino (descoberto em 1746) e Cabo Verde (descoberto em 1762), que pertenceram aos termos das Vilas de São João del Rei (1712) e posteriormente de Campanha da Princesa (1798) -, de forma que não convém retomar essa discussão neste artigo. Buscamos avançar demonstrando a relação entre as 
circunscrições das capitanias, bispados e comarcas - descritos anteriormente -, os eventos de posse dos descobertos, e as campanhas e diligências militares nos sertões do Rio Grande, além da criação dos julgados.

Os descobertos de ouro feitos nos sertões do Rio das Mortes e do rio Grande impactaram, de forma decisiva, a geopolítica lusa de definição dos limites das capitanias de São Paulo e Minas Gerais. Os conflitos locais pela posse de lugares de mineração catalisaram movimentos de criação de novas freguesias e vilas nas duas capitanias.

A fundação de arraiais ${ }^{92}$ na região do Sertão do Rio das Mortes se iniciou quando, em 1737, foi fundado o arraial de Santo Antônio do Vale da Piedade do Rio Verde (atual Campanha, Minas Gerais). A freguesia homônima foi criada em 1741. Em 1745 foi descoberto ouro às margens do rio Sapucaí, data em que se fundou o arraial de Santana do Sapucaí. A paróquia de Santana do Sapucaí foi instituída em 1748 pelo Bispo de São Paulo. ${ }^{93} \bigcirc$ núcleo urbano de Ouro Fino também é representativo das disputas entre Minas Gerais e São Paulo: descoberto por paulistas em 1746, teve sua capela fundada em 1749.94

Os Sertões do Campo Grande, na atual região do Triângulo Mineiro, 95 permaneceram à margem das políticas de ocupação territorial da Coroa até a década de 1740. $O$ motivo era que toda a faixa entre as nascentes do rio São Francisco e o médio Rio Grande estava povoada por quilombos. Os governadores da capitania de Minas Gerais empenharam-se em tomar posse dos sertões do Campo Grande e do Rio Grande, região de litígio com a capitania de São Paulo, visando aumentar, com isso, a arrecadação do imposto da capitação. Eclesiasticamente, essa região à margem esquerda do rio São Francisco esteve vinculada ao bispado de Pernambuco, cuja sede localizava-se na cidade de Olinda durante as quatro primeiras décadas do século XVIII, 96 passando posteriormente a pertencer ao bispado de Mariana. ${ }^{97}$ Os meios empregados para a ocupação dessa região foram a abertura de caminhos, a fundação de capelas e freguesias e a instituição de registros, guardas e julgados. Diversas campanhas (1746, 1759, 1764 e 1769) foram realizadas por governadores mineiros com o objetivo de dizimar quilombos e controlar o acesso a uma região ainda pouco ocupada que julgavam pertencer a sua capitania. Para Andrade, a partir dessas expedições e da instituição de uma rota de Minas para Goiás, aumentaram as tensões naquela região, marcada pelo "enquadramento" dos poderes civil e eclesiástico. ${ }^{98}$ Segundo Guimarães, em 8 de agosto de 1746, Gomes Freire de Andrade, governador da capitania de Minas Gerais, escreveu ao rei denunciando a existência de quilombos no Campo Grande com mais de vinte anos. ${ }^{99}$ Esse ano marcou, portanto, o início das expedições para sublevação de negros aquilombados papa" (FONSECA, 2011, p. 119) à expansão portuguesa aos territórios do oeste. Esse direito do "uti possidetis religioso", instituído pela bula papal, definia o território luso como sendo todo espaço efetivamente ocupado e não reivindicado pelos castelhanos. Cf. Fonseca, op. cit.

82. Gouvêa (2001, p. 299).

83. Ibid., p. 229.

84. Fonseca, op. cit., p. 120.

85. Camargo (1952, p. 239).

86. Ibid., p. 239

87. Em 1735, o Conselho Ultramarino sugeriu ao rei a mudança do governo de São Paulo para as "Minas dos Guayases", diante da impossibilidade de controle de tão vasto território vinculado àquela capitania (MOURA, 2018, p. 165). Mesmo a sugestão não tendo sido acatada, a administração da capitania de $\mathrm{Mi}$ nas passou por modificações, como a implementação do imposto da captação, em 1736, e do Contrato das Entradas, em 1735 , acompanhada da instituição dos registros, em 1736. O imposto da capitação era cobrado por cada escravo, incidindo sobre todos os habitantes, mesmo aqueles que não exploravam o ouro e já pagavam o dízimo sobre o produto de suas fazendas, o que gerou grande protesto (FONSECA, 2011, p. 196). Estando o imposto vinculado aos habitantes economicamente ativos (proprietários de escravos) e não à produção do ouro, a saída encontrada foi tomar posse de núcleos de povoamento que surgiam nos confins da capitania (FONSECA, 2011, p. 197). Esse imposto também vigorou na capitania de Goiás a partir de 1736, após um ano de testes na capitania de Minas Gerais. Em 
Goiás, segundo Nádia Moura, os tributos eram ainda maiores do que nas Minas (MOURA, 2018, p. 165).

88. "Os julgados eram os territórios de jurisdição de um juiz ordinário, ou seja, de um juiz 'leigo' (sem título de bacharel) de primeira instância. Suas atribuições podiam ser menos amplas que as dos juízes ordinários das vilas: diferentemente dos concelhos, os julgados eram circunscrições com autonomia judiciária parcial - ou seja, sem jurisdição completa (cível, crime, administrativa, o que os tornava dependente de um concelho vizinho, em um ou mais aspectos" (FONSECA, 2011, p. 189).

89. Cruz (2016).

90. Para um exame detalhado da formação dessa rede urbana, cf. Almeida (2019) e Almeida e Pereira (2018).

91. Cf. Salgado e Pereira (2017a).

92. Segundo Fonseca (2011, p. 64) "arraial" é um termo genérico desde finais do século XVII para designar os pousos que bandeirantes criaram ao longo das trilhas de desbravamento do interior da região que viria a ser chamada de Minas Gerais. No século XVIII, o termo associou-se progressivamente às zonas mineradoras da colônia, em Minas, Goiás e Mato Grosso. O termo "arraial" foi utilizado para nomear as localidades dependentes de uma sede de conselho, portanto aplicável também às capelas e freguesias, de modo geral.

93. A paróquia foi fundada pelo bispo de São Paulo, D. Bernardo Rodrigues Nogueira. Segundo Almeida, com a morte do Bispo no mesmo ano, a posse eclesiástica paulista não se efetivou na região, tornando o bispo de Mariana res- nos confins da comarca do Rio das Mortes. ${ }^{100}$ Em 1744, o governador criou o Julgado de Campanha do Rio Verde, em um descoberto que acabara de ser anunciado às autoridades. ${ }^{101}$ Em 1746 foi a vez do Julgado do Sapucaí.

Em 9 de maio de 1748 foi promulgada a provisão régia, que determinava que os territórios do sul da colônia e os de Mato Grosso e de Goiás fossem separados da Capitania de São Paulo. ${ }^{102}$ De 1748 a 1765, a capitania de São Paulo deixou de existir como governo autônomo e foi rebaixada à condição de comarca juntamente com a comarca de Paranaguá, ambas subordinadas ao governo civil do Rio de Janeiro. ${ }^{103}$ A provisão determinou que Gomes Freire de Andrade seria o governador interino das capitanias (Rio de Janeiro, Minas e São Paulo). Em 27 de maio de 1749 foi efetuada uma divisão entre as capitanias de São Paulo e Minas Gerais, pelo ouvidor da comarca do Rio das Mortes, Dr. Thomas Ruby de Barros Barreto. ${ }^{104}$ Essa demarcação foi interpretada como uma linha reta, partindo do Morro do Lopo, passando pela serra de Mogi Guaçu até encontrar o Caminho dos Goiases, rumo ao fim da demarcação no Rio Grande. ${ }^{105}$

Na segunda metade do século XVIII, com o esvaziamento da produção aurífera em Minas Gerais, ocorreu uma progressiva migração de mineiros em direção ao sertão do Rio Pardo - evidentes nos censos da capitania de São Paulo 100 - além de uma diversificação da produção agrícola e de um incremento na fundação de novas vilas e freguesias por ambos os governos, como parte de uma estratégia de expansão territorial. Em adição à escassez do ouro, à fuga de mineiros da cobrança da "derrama" e ao imposto da capitação, ampliou-se a lavoura mista na porção oeste da capitania de Minas Gerais. Nessa conjuntura, é forçoso destacar que a urbanização na segunda metade do século XVIII atendeu a "novas exigências que se apresentaram no processo de demarcação de fronteiras com os espanhóis". ${ }^{107}$ A mudança da concepção de soberania territorial, antes baseada na posse virtual de espaços desconhecidos, para o conceito de território espacialmente definido foi adotada no Tratado de Madri, de 13 de janeiro de 1750. ${ }^{108}$ Essa mudança de paradigma teve fortes consequências no processo de ocupação dos sertões do Rio Grande e do Rio das Mortes: segundo o conceito do uti possidetis, como nos explica Maria Fernanda Derntl, "reconhecia-se a legalidade e a legitimidade do poder estatal que de fato exercesse controle político e militar sobre uma região. Em outras palavras, a ocupação definiria a posse". 109 


\section{Descoberto de Jacuí}

Esse descoberto estava localizado ao sul do Rio Grande, em uma região que, em meados do século XVIII, foi percorrida e desbravada por oficiais da Câmara da Vila de Jundiaí que a consideravam como parte do termo dessa vila. Em 1755, Pedro Franco Quaresma 110 tomou posse do "Sertão do Rio São João (de Jacuí)", 111 afluente do Rio Grande, em nome do ouvidor da comarca de São Paulo. No auto de posse, 112 a hidrografia da região foi utilizada como referência para delimitar o descoberto:

do Rio de São João que faz barra no dito Rio grande, e por elle acima té onde finalizar o dito Pedro Franco com a sua deligencia, e tão bem de todo o Certão além do dito Rio S. João até o Rio de Sapocahy da Campanhas de Itajubá. ${ }^{113}$

bispado de São Paulo procurava estender suas posses até o rio Sapucaí, nos limites de seu domínio. Todas essas posses civis e eclesiásticas foram justificadas pela bula Motu Proprio, de 1745, que definira o Rio Grande como limite entre os bispados de São Paulo e Minas Gerais. Embora a capitania de São Paulo tivesse perdido sua autonomia desde 1748, foi por meio da comarca de São Paulo que o governo civil manifestou sua posse nos sertões do Rio Grande. Entre 1755 e 1762 foram feitos vários autos de posse nos rios São João, São Pedro de Alcântara e Almas, além de seus vários tributários. Em 1761, o mesmo Pedro Franco Quaresma tomou posse do "Ribeirão de São Pedro de Alcântara e Almas", na região da atual Jacuí, Minas Gerais, dando ao local o nome de Arraial de São Pedro e Almas do Emboque. ${ }^{114}$ Essa posse também foi feita em nome da Vila de Jundiaí. Embora referidos por nomes distintos - sertão do rio São João, São Pedro de Alcântara e Almas, Jacuí e sertão do Desemboque - a região dos descobertos se situava em rios tributários do Rio Grande, como se pode observar na Figura 3. A toponímia designa diferentes lugares nos sertões do Rio Grande, que englobavam os sertões de Jacuí e do Desemboque.

Os mapas são fortes argumentos pela posse dos sertões. A forma como o Descoberto de São João de Jacuí está representado na cartografia (Figura 3) revela a ideia de uma região com contornos definidos por serras que parecem circunscrever com precisão o descoberto, representação que não corresponde à configuração real do relevo desse território. O mapa apresenta, por exemplo, a "Serra do Dumbá ou da Mantiqueira" como se as duas estivessem unidas em um único braço que divide as águas vertentes do rio Pardo. A representação é feita de modo que o novo descoberto seja circunscrito por afluentes dos rios São Pedro e São João, sem uma localização clara. Podemos deduzir, a partir da representação desse mapa, ponsável pelo território a oeste do Sapucaí (ALMEIDA, 2019, p. 91).

94. A capela de S. Francisco de Paula do Ouro Fino foi instituída em paróquia encomendada, em 1749, pelo bispado de São Paulo. No entanto, como os limites entre as capitanias de Minas e São Paulo não estavam bem definidos, o rei de Portugal, D. João V, ordenou que Ouro Fino passasse e pertencer à capitania de Minas Gerais. "A freguesia de Ouro Fino ficou então subordinada ao bispado de São Paulo e sob jurisdição da vila de São João Del Rey" (SALGADO; PEREIRA, 2017a, p. 230). Em 1750, contudo, o reverendo João Bernardo da Costa Estrada tomou posse da capela de S. Francisco de Paula do Ouro Fino como procurador do bispo de Mariana.

95. Luís Augusto Lourenço demonstra a ocupação dessa região em sua pesquisa. Para ele, o Triângulo permaneceu como "corredor para o tráfego de tropas para São Paulo por quase um século" (LOURENÇO, 2005, p. 21).

96. Fonseca, op. cit., p. 119. 97. Ver Figura 2.

98. Andrade (2011, p. 284). 99. Guimarães (1988, p. 16). 100. Ibid.

101. Fonseca, op. cit., p. 193).

102. Documentos interessantes para..., 1896, p. 41.

103. Lustosa (1975, p. 909).

104. Campanhole, op. cit., p. 4.

105. Cf. Salgado e Pereira, op. cit. 
106. Cf. Bacellar e Brioschi, op. cit.

107. Derntl (2013, p. 45).

108. Ibid., p. 46

109. Ibid., p. 46

110. Pedro Franco Quaresma foi juiz ordinário da vila de Jundiaí, nomeado em 2 de janeiro de 1763 (CAMPANHOLE, 1979, p. 54).

111. ARQUIVO PÚBLICO DO ESTADO DE SÃO PAULO. Documentos interessantes para..., op. cit., p. 63.

112. Ibid., p. 63.

113. Ibid., p. 63.

114. Campanhole, op. cit., p. 54 .

115. De acordo com Fonseca, o termo "país" designava regiões em ocupação, mas não tão bem delimitadas quantos os "arraiais", "lugares" e "sítios". Esse termo e seus correlatos ("continente" e "distrito") podem estar associados ao temo "sertão" como forma de qualificar locais pouco conhecidos ou explorados (FONSECA, 2011, p. 80). Nesse sentido, é justificável a adoção do termo "pays dos quilombos" no referido mapa.

116. Bluteau (1728, p. 229).

117. Fonseca, op. cit., p. 28.

118. ARQUIVO PÚBLICO DO ESTADO DE SÃO PAULO. Documentos Interessantes para..., op. cit., p. 98. Nessa carta, o governador de Santos refere-se aos "Arrayaes de Santa Anna, São Pedro de Alcantara, São João do Jacuí, e Asumpção de Cabo Verde" (ARQUIVO PÚBLICO DO ESTADO DE SÃO PAULO, 1896, p. 98, grifo nosso).

119. Almeida, op. cit., p. 49. que a toponímia "descoberto" designava uma região com contornos indefinidos, que poderia conter outros núcleos de povoamento, como capelas e paróquias. Próximo à referida Serra do Dumbá há uma importante inscrição: "Pays dos Quilombos". 115 É uma clara indicação dos vários quilombos existentes nesse sertão que foram alvo de expedições de extermínio pelo governo de Minas Gerais. A maioria dos núcleos urbanos é designada por "aldea". De acordo com o dicionário de Raphael Bluteau, "aldea" significa povoação, menor que "lugar". 116 Fonseca afirma que o termo "aldeia" designava, em Portugal, os núcleos que não gozavam de autonomia jurídico-administrativa, toponímia que, na colônia, adquiriu uma conotação étnica, indicando os locais de gentios. ${ }^{117}$ No mapa, o termo "aldea" foi utilizado para designar, de forma genérica, núcleos urbanos que não detinham autonomia jurídico-administrativa, mas já tinham status como capelas, freguesias e arraiais. Por sua vez, os núcleos urbanos que constituíam sedes de concelhos, caso da Vila de Jundiaí, que reivindicava a posse dessa região, e da cidade de São Paulo, foram indicados com esses topônimos. Não foi possível identificar a origem de outros dois núcleos representados no mapa: Aldea de S. João e Aldea de S. Anna. Apesar disso, localizamos uma menção a eles em uma carta do governador de Santos ao governador de São Paulo ${ }^{118}$ que relata estarem esses arraiais dentro do que se entendia como as Minas do Desemboque.

A representação dos rios Grande e Sapucaí, como dois cursos caudalosos, pode ter sido feita de modo a reforçar sua importância enquanto marcos referenciais nas sucessivas delimitações de fronteiras civis e eclesiásticas. Outro ponto a ser destacado é a representação do sertão do Campo Grande na divisa com o Rio Grande. $\bigcirc$ mapa apresenta o principal território em litígio entre as capitanias e os bispados, cujos caminhos principais conectavam o Caminhos dos Goiases e o de Fernão Dias. Apesar de não constar a data do documento original, aventamos a hipótese de que o mapa foi elaborado após 1762, data do descobrimento das minas de ouro em Cabo Verde, que figura com a legenda: "Aldea do descuberto de Cabo Verde", e antes de 1769, ano de elevação de Mogi Mirim a vila, pois o local ainda era designado por "Aldea".

A exploração dos sertões ao norte de Ouro Fino, em 1762, por João Veríssimo de Carvalho, resultou em um novo descoberto de ouro de aluvião às margens do rio Assumpção. Veríssimo passou então a residir com a família na região, fundando o arraial de Cabo Verde. ${ }^{119}$ A capela existente no local foi elevada a curato, em 1766, pelo bispo de São Paulo, passando a denominar-se N. Sra. da Assumpção. ${ }^{120}$ Junto com o Descoberto de São João de Jacuí, os descobertos de Cabo Verde e de Ouro Fino, mais ao sul, integraram uma rede de núcleos urbanos no sul da comarca do Rio das Mortes - visível no mapa da Figura 
3 - marcados pela constante tensão entre os governos de Minas Gerais e São Paulo. Tais localidades materializaram uma série de conflitos que advinham da sobreposição entre os territórios dos bispados e das capitanias.

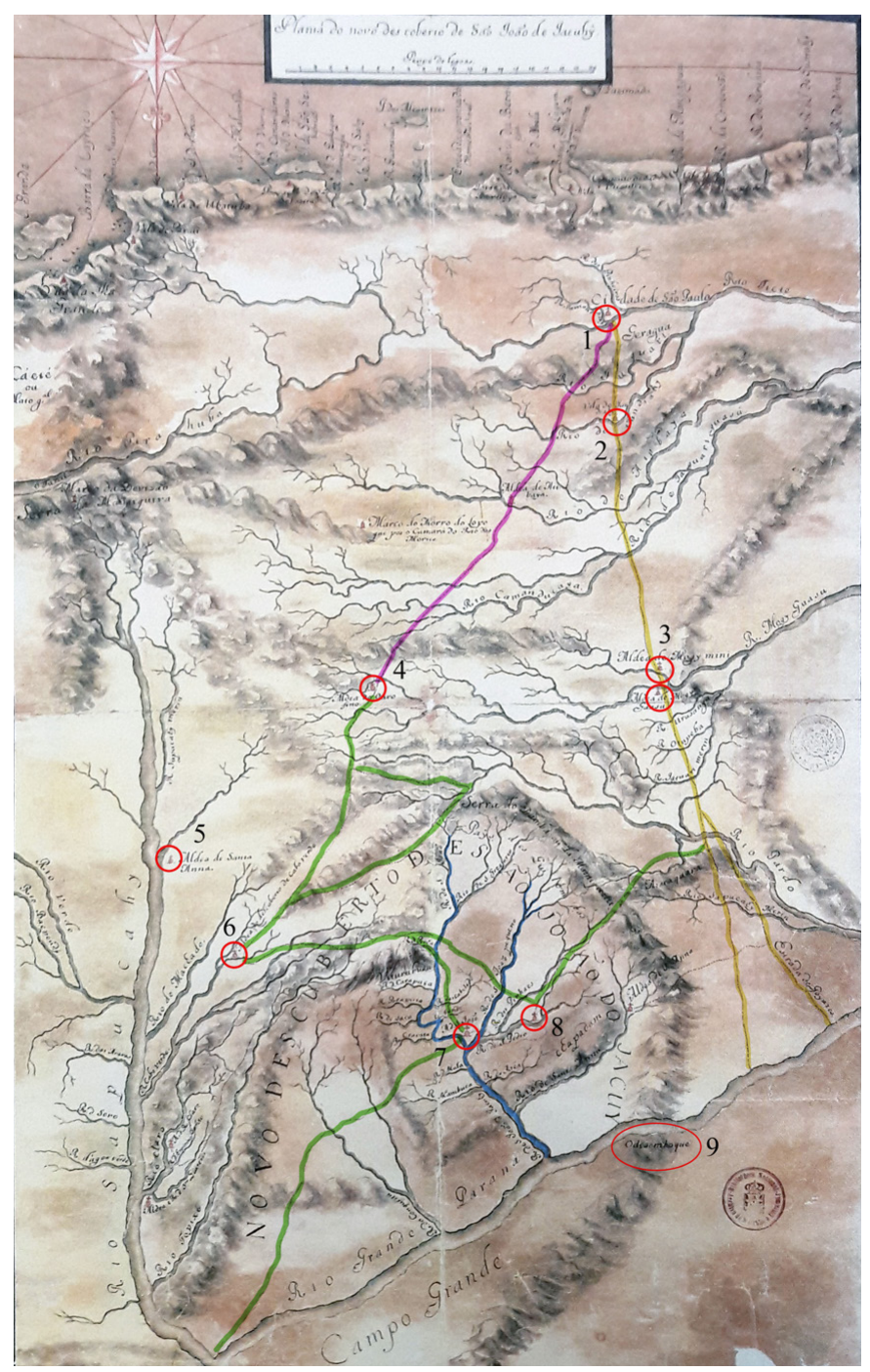

Figura 3 - "Planta do novo descoberto de São João de Jacuí" (século XVIII). Destacamos no mapa o Caminho dos Goiases, em amarelo, e um trecho do Caminho de Fernão Dias, em roxo, assim como suas ramificações em direção a freguesias e povoados mineiros e paulistas, em verde. Em azul foram destacados o rio São João de Jacuí, que deságua no Rio Grande, e o rio São João Pequeno, afluente do primeiro. Em vermelho, as seguintes localidades: 1) Cidade de São Paulo; 2) Vila de Jundiaí; 3) Aldea de Mogi Mirim; 4) Aldea de Ouro Fino; 5) Aldea de Santa Anna (Santana do Sapucaí); 6) Aldea do descuberto de Cabo Verde; 7) Aldea de São João; 8) São João de Jacuí e 9) "O Desemboque". Fonte: Rede Memória - Coleção Cartográfica e Iconográfica Manuscrita do Arquivo Histórico Ultramarino. Documento original: Escala [ca. 1:1.000.000]. 1 carta colorida, desenho a nanquim; 61,9 × $39 \mathrm{~cm}$ em folha 67,4 × 44,4 cm. Disponível em: <https://bit.ly/3btlYzH>. Acesso em: 27 mar. 2020. 
121. Senna (1924, p. 276).

122. Carvalho (1998, p. 3233).

123. Segundo Nelson de Senna, o sentido da palavra "desemboque" está relacionado ao ponto onde se uniam ou desembocavam dois caminhos: a Picada de Goiás, passando pelo oeste mineiro através de Pitangui, Bambuí, Araxá e Uberaba; e o Caminho de Goyas, que atingia o triângulo mineiro: "o ponto fatal em que as duas estradas faziam junção ou 'desembocavam' era no arraial do Desemboque, no taboleiro [sic] araxano" (SENNA, 1937, p. 277). Acreditamos que o topônimo "desemboque" esteja relacionado à situação geográfica dessa região, ou seja, à desembocadura de caminhos e de afluentes do Rio Grande. No dicionário de Raphael Bluteau, "desembocar" significa "sahir da boca de hum rio, de hum Estreito, ou Braço de mar" (BLUTEAU, 1728, v. 3, p. 125). No dicionário de Antônio Moraes Silva, o vocábulo também assume o sentido de "chegar o rio com a sua boca, e desaguar por ella as águas, a outro rio, ou mar" (SILVA, 1789, p. 659).

124. Martins também aventa a possibilidade da existência de dois locais com o nome de "Desemboque" (MARTINS, 2008, p. 544).

125. O Arraial do Desemboque estava localizado às margens do Rio das Velhas, em um dos caminhos tributários do Caminho dos Goiases. Barbosa (1971) nos esclarece que o Arraial do Desemboque data de meados do século XVIII, sendo um dos mais antigos da região. O povoado do Desemboque surge como garimpo às margens do Rio das Velhas. Fundado aproximadamente entre 1736 e 1740 por mineiros vindos de Tamanduá e Pitangui, ele teria
Sobre a toponímia "Cabo Verde" há duas versões. Para Nelson de Senna, a presença de inúmeros rochedos diabásios conhecidos pelo nome vulgar de cabo verde, nos vales dos rios Mozambo e Cabo Verde, conferiram à região essa toponímia. ${ }^{121}$ Adilson de Carvalho, por sua vez, afirma que a origem do nome está relacionada à presença dos negros chamados "cabo-verde", provenientes da Bahia, que constam nos registros de batismo de 1780 dessa freguesia como "pretos cabo-verde". ${ }^{122}$

\section{O Descoberto do Desemboque}

Na documentação analisada, a toponímia "desemboque"123 se refere a duas localidades com status diferentes: o sítio e paragem do "Dezimboque", na passagem do Rio Grande, e o Arraial do Desemboque, na margem sul do Rio das Velhas (atual rio Araguari), 124 fundado por mineiros na década de 1740, 125 no sertão da Farinha Podre, ${ }^{126}$ que foi objeto de disputa entre os governos de São Paulo, Minas Gerais e Goiás. ${ }^{127}$

Em 1766 foi criado, pela capitania de Goiás, um posto de julgado no Arraial do Desemboque: julgado das Cabeceiras do Rio das Velhas, representado no mapa da Figura 4. ${ }^{128}$ A posse goiana no Desemboque desagradou às autoridades de Minas Gerais que, no entanto, preferiram agir com diplomacia. ${ }^{129}$ Márcia Amantino defende a tese de que a incorporação dessa região ao território goiano tinha razões fiscais, pois dessa forma seus habitantes não permaneceriam sujeitos ao imposto da derrama. ${ }^{130}$

Segundo Barbosa, a "estrada que ligava São Paulo a Goiás cortava o Rio das Velhas um pouco mais abaixo [do arraial do Desemboque], justamente onde se localizava o registro". ${ }^{131}$ Esse trajeto é visível no mapa de 1796 (Figura 4): o Caminho dos Goiases cruzava o Rio Grande e, mais acima, havia uma bifurcação até o arraial do Desemboque; na continuação do Caminho dos Goiases chegava-se ao Registro do Rio das Velhas. ${ }^{132}$

No mapa da Figura 4 destacamos ainda a relação do arraial do Desemboque, sede do julgado do Rio das Velhas, com as freguesias de Jacuí (criada em 1762) e de Cabo Verde (1769), e com o descoberto do rio Pardo (1765). Esse descoberto foi elevado a Freguesia de N. Sra. da Conceição do Bom Sucesso do Rio Pardo em 1775. As guardas militares de Minas Gerais são representadas por bandeiras azuis e as de Goiás por bandeiras vermelhas. Há também o símbolo de uma cruz vermelha indicando as freguesias. 


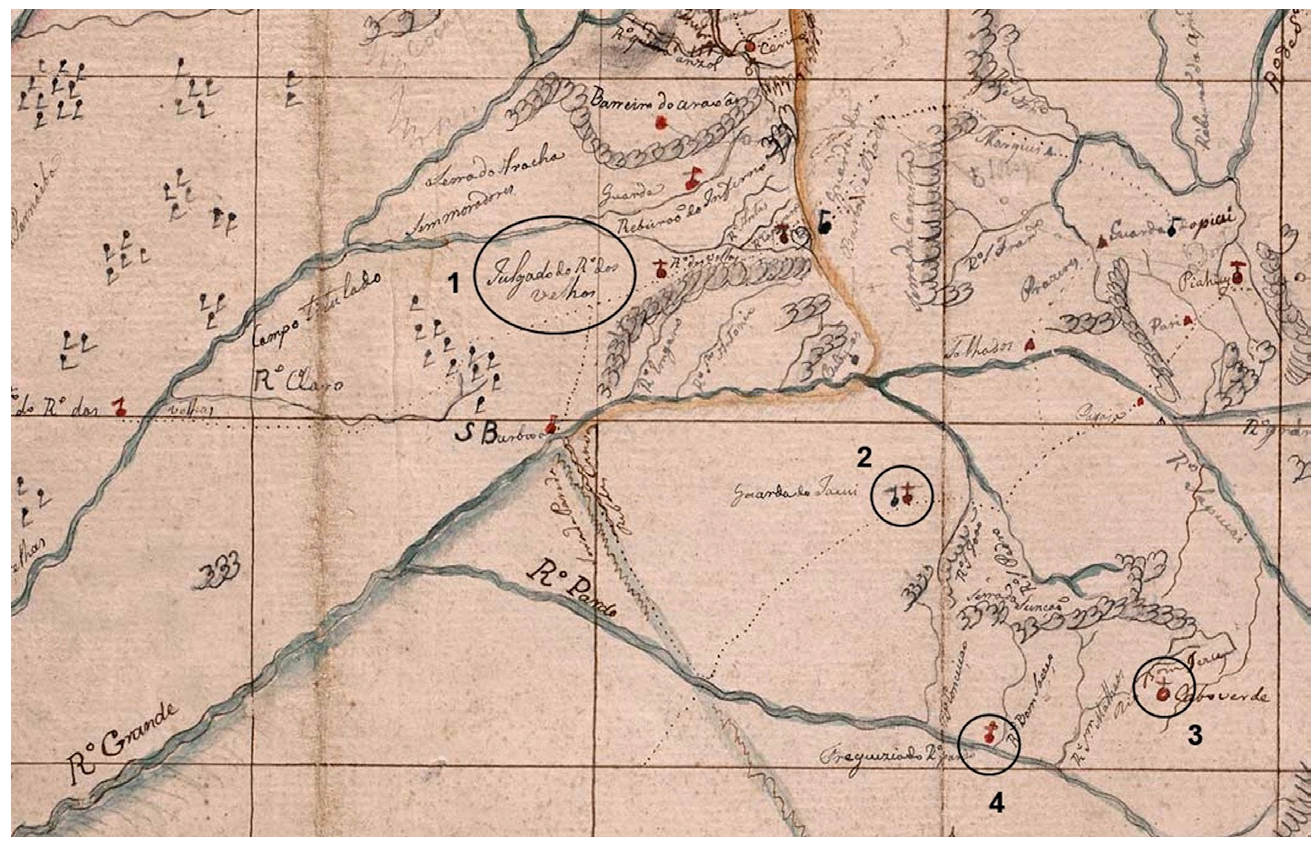

Figura 4 - Recorte do mapa de José Joaquim da Rocha: "Mostrace [sic] neste mapa o julgado das cabeceiras do rio das Velhas e a parte da Capitania de Minas Gerais com a devisa [sic] de ambas as capitanias dadas pelo capitam. No que as bandeirolas azuis são guardas de Minas, e as vermeIhas são de Tropas de Goiás", de 1796. Estão destacados: 1) Julgado do Rio das Velhas (Arraial do Desemboque); 2) Guarda de Jacuí, cujo símbolo está junto da Freguesia de Jacuí; 3) Freguesia de Cabo Verde e 4) Freguesia do Rio Pardo. Fonte: Biblioteca Nacional. Disponível em: <https:// bit.ly/2UCQcQd>. Acesso em: 1 abr. 2020.

Mas há também menções, na documentação da segunda metade do século XVIII, ao sítio e à paragem do Desemboque, na passagem do Caminho dos Goiases no Rio Grande, bem como aos sertões do Desemboque, incluindo outros descobertos auríferos próximos aos sertões de Jacuí. É a essa região que dedicamos uma análise mais detalhada. No mapa da comarca do Rio das Mortes, de 1777, de autoria de José Joaquim da Rocha, há indicação de um sítio ${ }^{133}$ com nome "Dezimboque", logo adiante da passagem do Rio Grande (Figura 9).

$\bigcirc$ sítio ou paragem do Desemboque, desde sua posse pelo governo paulista em meados do século XVIII, até o início do século XIX, representou um ponto-chave nos projetos de ocupação do sertão do Rio Grande. Sua posse foi feita em nome da câmara da vila de Jundiaí e do bispado de São Paulo. No "Auto de Posse do Desemboque", 134 de 4 de setembro de 1761, estavam o padre Marcos Freire de Carvalho, por ordem de D. Frei Antônio da Madre de Deus, bispo de São Paulo, em companhia do escrivão Mathias de Souza Mursa. Reunindo-se todos na "paragem do Rio Grande", 135 tomaram posse dos descobertos do Desemboque e de outros rios afluentes do Rio Grande: sido destruído em 1750 pelos índios Caiapós, depois reerguido três léguas abaixo do primeiro, com o nome de povoado de N. Sra. do Desterro das Cabeceiras do Rio das Velhas (BARBOSA, 1971, p. 205). A matriz teria sido construída em 1743, informação encontrada no acervo iconográfico do Arquivo Público Mineiro. Segundo o Instituto Estadual do Patrimônio Histórico e Artístico de Minas Gerais (Iepha), a Matriz de N. Sra. do Desterro do Desemboque foi construída entre 1743 e 1754 e adoção orago N. Sra. do Desterro pode estar relacionada ao isolamento da região: "desterro" significa solidão, "insulamento" (INSTITUTO ESTADUAL DO PATRIMÔNIO HISTÓRICO E ARTÍSTICO DE MINAS GERAIS, 2014, p. 205).

126. O "Sertão da Farinha Podre" designava uma região próxima aos atuais municí pios de Uberaba e Uberlândia, no atual Triângulo Mineiro. Essa denominação, contudo, se generalizou para a região do desemboque.

127. Segundo a descrição de Almeida, o padre Marcos Freire de Carvalho havia sido provisionado pelo bispo de Mariana e exercia seu ministério na zona de Jacuí (BARBOSA, 1971, p. 170). O padre teria tomado conhecimento da existência do arraial do Desemboque, oferecendo a posse da paróquia ao bispado de Goiás, sem contudo obter resposta. Dirigiu-se então para São Paulo, oferecendo o arraial ao bispo D. Antônio da Madre de Deus, que o nomeou vigário do Desemboque. A versão de Waldemar de Almeida corrobora a descrição do supracitado auto de posse dos sertões do Desemboque, pois, segundo o documento, o padre Marcos Freire de Carvalho tomou posse pelo bispado de São Paulo e não por Mariana, por meio do qual havia sido 
promovido ao ministério em Jacuí. Lourenço nos apresenta uma versão um pouco diferente. Segundo o autor, o padre Marcos Freire de Carvalho, do Desemboque, abriu uma picada desse arraial até Santa Cruz, na capitania de Goiás (LOURENÇO, 2005, p. 114). O bispo de Goiás reconheceu a paróquia do Desemboque como sua jurisdição, provisionando o padre Félix José Soares, ligado ao padre Marcos Freire como vigário em 1765 , o que provocou a reação do bispado de Mariana (LOURENÇO, 2005, p. 114).

128. Fonseca nos esclarece a data do original desse mapa: 1780; a cópia feita em 1796 , ora apresentada, é de autoria de Joaquim José da Rocha (FONSECA, 2011, p. 623).

129. Ibid., p. 203.

130. Amantino (2003, p. 90).

131. Barbosa, op. cit., p. 44.

132. Segundo Barbosa (1971, p. 44): "De São Pedro de Alcântara de Almas do Jacuí partiam grupos de mercadores, com seus carregamentos de mercadorias, por uma picada que terminava no Desemboque. [...] Mercadores em número cada vez maior, com intuito de fugir ao fisco, evitavam o Registro do Rio das Velhas (hoje, Araguari), mais abaixo, e foram criando uma picada além do Desemboque, rumo ao norte, forjando guias falsas do direito que deveria ser pago naquele registro. Assim, tornou-se conhecida a região onde se localiza Araxá".

133. O termo "sítio" denotava a implantação, sobretudo em áreas rurais, onde a densidade demográfica era menor do que nos "lugares" ou "arraiais". O termo refere-se a uma ocupação mais estável, que poderia ou não evoluir para
Aos vinte e quatro dias do mez de Setembro de mil setecentos e sessenta e hum annos, no sertão do Rio Grande, bispado de S. Paulo, a que serve de demarcação ou termo dividente o mesmo Rio Grande, e nas margens d'elle da parte do Poente, fronteira ao sol, que nasce das Geraes, junto da picada, que fizerão as companhias militares, que vierão conquistar os negros fugidos do dito sertão e do Campo Grande, ahi na dita paragem lestando o povo juntol apresentou o padre Marcos Freire de Carvalho huma ordem do Excellentissimo Senhor Bispo de S. Paulo, D. Fr. Antonio da Madre de Deos, em que lhe ordenava, que como seu delegado e vice-gerente tomasse posse actual e pessoal dos novos descobertos de ouro, que no dito sertão do Rio Grande se tinha feito, ou em diante se fizessem, por estarem todos dentro nos limites da jurisdiçção do dito Sr. Bispo, conforme o motu próprio do Santissimo Padre Benedicto Decimo Quarto, ex-vi da qual ordem aposse ou elle dito padre os descubertos chamados o Desemboque, Ribeirão de Santa Anna, Córrego Rico, Ribeirão das Almas, e Ribeirão Grande, vertentes do Rio de S. João, e para haver de apossear este dos Macieis, como também o Ribeirão do Pinheiro, que faz barra no Sapucahy [...] que tudo fica dentro no mesmo bispado, como declararão os moradores da mesma paragem, que se acharão no acto da posse, e para apossear também o mesmo Rio de $\mathrm{S}$. João, a que os Bandeirantes das Geraes puseram o nome de Jacuhy. ${ }^{136}$

Fica evidente que a toponímia "desemboque" se referia aos mesmos sertões de Jacuí, analisados anteriormente. Dos rios indicados no auto de posse, localizamos apenas o Ribeirão de Santa Anna e o rio São João, no mapa do "Descoberto de São João de Jacuhí" (Figura 3). Os outros rios podem ter tido seus nomes alterados. Pela descrição, o padre e as demais pessoas estavam em uma "paragem" às margens do Rio Grande, em uma picada (caminho) que poderia estar localizada na passagem do Rio Grande, em uma das derivações do Caminho dos Goiases que se vê no mapa da Figura 3. Por meio dessa descrição percebe-se que o padre Marcos Freire, estando na paragem do Rio Grande, tomou posse também de outros lugares. $\bigcirc$ rito efetivou-se com os atos possessórios seguintes: "mandou [o padre] arvorar o Estandarte Real da Santa Cruz, e revestido de Estola e sobrepeliz (depois de benzer agoa) prosseguiu com uma prática expondo as palavras do texto - Ecce crucem domini", 137 o que conferiu a posse daquele "continente"138 ao bispado de São Paulo que, por ora, devia dar obediência ao vigário encomendado de Mogi Guaçu. ${ }^{139}$

Entre 3 de agosto e 3 de dezembro de 1764 o governador mineiro D. Luís Diogo Lobo da Silva empreendeu uma "diligência" pela capitania de Minas, percorrendo 365 léguas em regiões de fronteira. Enviou uma "Relação das Marchas" ao governo em Lisboa, em 22 de janeiro de 1765, descrevendo minuciosamente o percurso no qual diversos arraiais, capelas e quilombos foram identificados. ${ }^{140}$ Segundo Ivone Salgado e Renata Pereira, D. Luiz Diogo mandou realizar uma carta geográfica contendo o roteiro feito em 1764 por sua diligência. No Arquivo Público Mineiro há uma cópia desse mapa (Figura 5), que também consta como anexo ao Volume XI dos Documentos interessantes.... ${ }^{141}$ 
Nos sertões do Rio Grande, o percurso da comitiva atravessou o rio homônimo, cruzou o Rio de São João do Jacuí e chegou ao arraial de São Pedro de Jacuí, onde o governador estabeleceu regimentos para impedir o extravio de ouro e diamante. Criou, ainda, o julgado de Jacuí, que incluía o sertão do Desemboque e outros núcleos, onde anteriormente havia posses paulistas, ${ }^{142}$ por meio de um "assento" dos descobertos de S. Pedro de Alcântara e Almas (Jacuí), determinando que no arraial do descoberto houvesse um cabo e dois soldados ${ }^{143}$ para o patrulhamento da região. De Jacuí, a comitiva seguiu para Cabo Verde, alcançando os quilombos de Zundum e Dumbá (Figura 6). A expedição abriu picadas, instituiu registros e tomou posse de paróquias que antes estavam sob o poder do bispado de São Paulo. Almeida esclarece que a capela curada de Cabo Verde e as freguesias de Jacuí, Ouro Fino e Santana do Sapucaí estavam até então sob jurisdição do bispado de São Paulo, e que passaram a pertencer ao bispado de Mariana a partir daquela data. ${ }^{144}$

$\bigcirc$ que estava de fato em jogo era a posse civil e eclesiástica, por parte de Minas Gerais, das paróquias nos sertões e seu desdobramento na definição das fronteiras da capitania. Para Cláudia Damasceno Fonseca, os atos do governador de Minas, em 1764, constituíram argumentos posteriores para a divisão das capitanias, favorecendo os mineiros: "desta maneira, todas as terras visitadas por Luís Diogo ficaram incluídas no território de Minas Gerais". ${ }^{145}$ Fica evidente, por causa desse evento, que as terras foram conquistadas com base no conceito do uti possidetis.

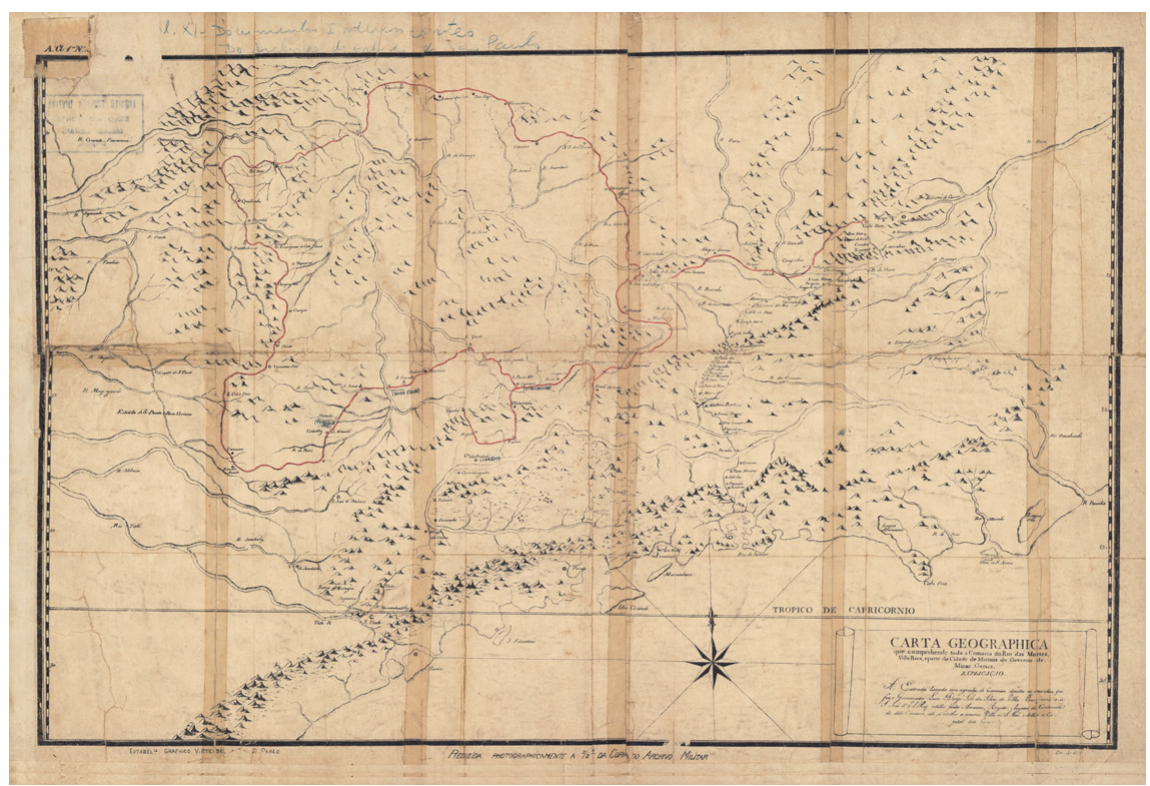

Figura 5 - Carta Geográfica que compreende toda a comarca do Rio das Mortes, Villa Rica, da cidade de Mariana e do Governo de Minas Gerais. Sem data. Esse mapa também se encontra em anexo em: ARQUIVO PÚBLICO DO ESTADO DE SÃO PAULO. Documentos interessantes... op. cit. Fonte: Arquivo Público Mineiro. Disponível em: <hitps://bit.ly/2UUCgQg>. Acesso em: 31 mar. 2020. outras formas de ocupação (FONSECA, 2011, p. 78).

134. Documentos interessantes para..., op. cit., p. 66.

135. A expressão "paragem" era um termo genérico que designava as "terras situadas em torno de um marco geográfico" natural ou artificial, frequente nos pedidos de sesmarias (FONSECA, 2011, p. 77).

136. Documentos interessantes para..., op. cit., p. 66, grifos nossos.

137. Do latim para o português: "Eis a cruz do Senhor" (tradução livre).

138. O termo "continente" aparece como sinônimo de "arrabalde" ou "vizinhança", enquanto espaço justaposto a um outro. Poderia ser empregado para designar regiões administrativas, civis ou eclesiásticas: freguesias, comarcas e mesmo a capitania no seu conjunto (FONSECA, 2011, p. 80).

139. Eclesiasticamente, a freguesia de Mogi Guaçu tinha como limite o Rio Grande. Os fregueses que estivessem nesse território estariam subordinados ao vigário da paróquia de Mogi Guaçu.

140. O itinerário completo dessa viagem encontra-se no Arquivo Público Mineiro, em correspondência na qual o governador descreve minuciosamente as reformas que fez nas companhias de ordenanças - formadas também por pretos forros - e fala até mesmo em ajudar a Coroa contra os espanhóis: "refletindo não ser menor a consequência de ficarem as ditas Milicias em distância proporcionada de poderem socorrer as de S. Paulo, que lhes são confinantes, quando estas careção de se reforçarem com o seus [ilegível] contra a má fé dos vários hespanóis”, mas volta atrás dizendo não 
ter "a experiência necessária em semelhantes matérias" (RELLAÇ̃̃O das marchas..., 1765).

141. Documentos interessantes para..., op. cit.

142. Fonseca, op. cit., p. 199-200.

143. Documentos interessantes para..., op. cit.

144. Almeida, op. cit., p. 95. A autora faz um bom resumo das ações de D. Luiz Diogo em seu "giro": "depois de tomada a posse de Jacuí, o governador também passa por Cabo Verde, Ouro Fino, Camanducaia, Capivari e Itajubá, estabelecendo registros em Jacuí, Cabo Verde, Ouro Fino, no Rio Jaguari próximo a Camanducaia e em Itajubá. Jacuí, Itajubá e Camanducaia estavam na posse da Capitania de São Paulo. Cabo Verde empossado pela capitania mineira, porém sob o Bispado de São Paulo. Luiz Diogo regulariza os registros que tinham ficado nas imediações de Santana do Sapucaí, Ouro Fino e Cabo Verde e define limites favorecendo os mineiros" (ALMEIDA, 2019, p. 52).

145. Fonseca, op. cit., p. 200.

146. Andrade (2007).

147. Ibid., p. 152.

148. Id., 2008, p. 1.

149. Ibid., p. 1.

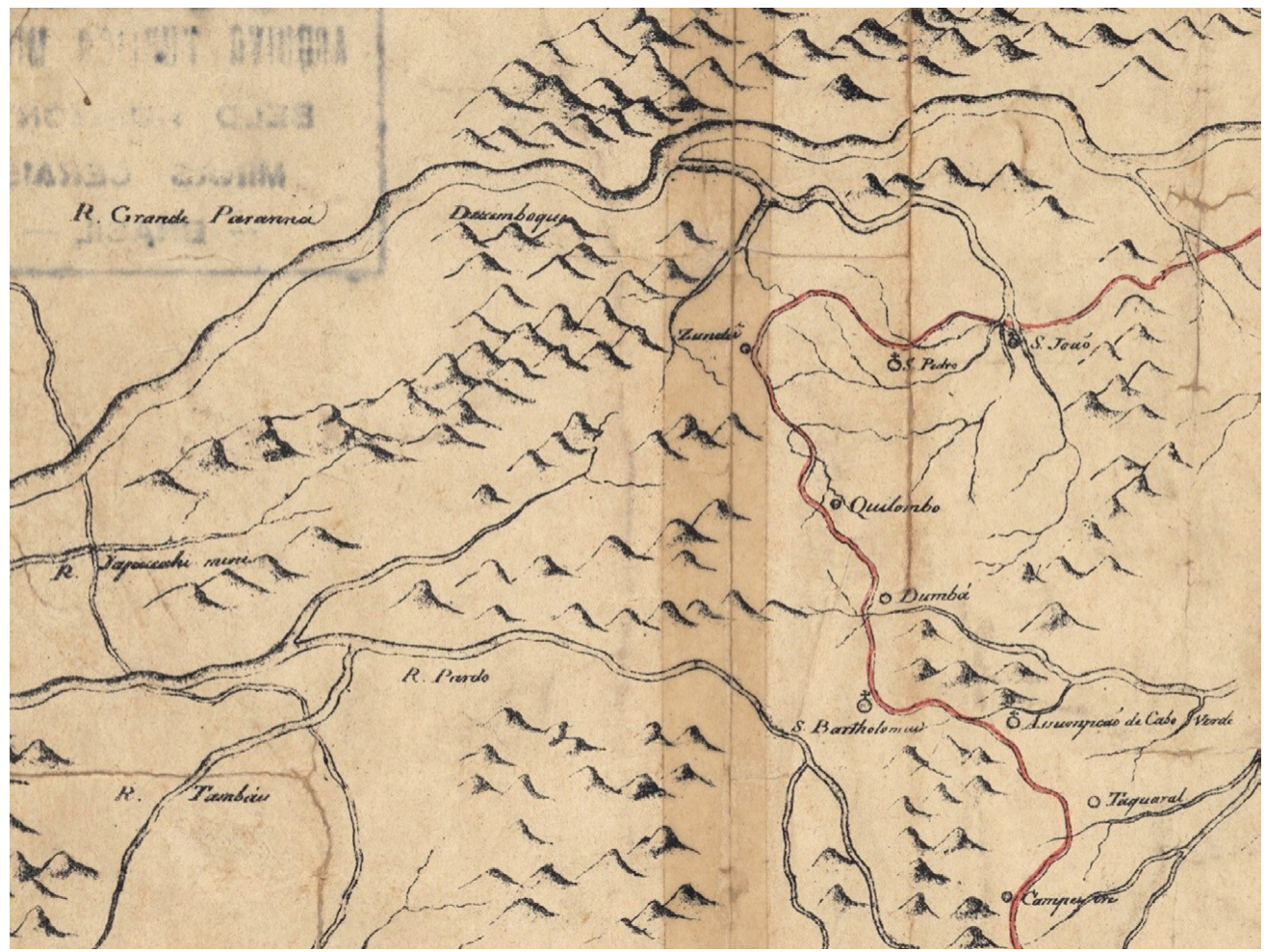

Figura 6 - Trecho da Carta geográfica que compreende toda a comarca do Rio das Mortes, Villa Rica, da cidade de Mariana e do Governo de Minas Gerais, representando, em vermelho, o trajeto percorrido por D. Luiz Diogo na fronteira com a capitania de São Paulo. Fonte: Arquivo Público Mineiro. Disponível em: <https://bit.ly/2UUCgQg>. Acesso em: 31 mar. 2020.

Francisco Eduardo de Andrade constrói uma análise compreendendo a instituição de capelas e arraiais como meios de conversão dos sertões de Minas Gerais. ${ }^{146}$ Para o autor, a existência de uma capela, mesmo que não correspondesse a uma "povoação com edificações e relações locais visíveis", podia significar a existência de um lugar estratégico. ${ }^{147}$ Com base nessa afirmação, Andrade defende que o lugar da capela surgia antes mesmo de sua instituição. Isso de fato ocorreu nos sertões do Rio Grande, onde percebe-se que houve a fundação de capelas em locais estrategicamente localizados: em descobertos auríferos e em regiões de lifígio. É o caso de Jacuí, descoberto em 1755, com posse pelo bispado de São Paulo e pela Vila de Jundiaí, com ereção de altar móvel; Cabo Verde, descoberto em 1762 e com ereção de capela curada em 1766; e Caconde, descoberto em 1765 e elevado a freguesia em 1775, pelo bispado de São Paulo. No processo de colonização e de ocupação dos sertões, as instituições locais (notadamente as capelas) desempenharam papel fundamental, representando o enraizamento da jurisdição do Estado nas "práticas costumeiras de poder dos coloniais", ${ }^{148}$ estreitando laços entre a Coroa portuguesa, as jurisdições senhoriais e as autoridades locais. ${ }^{149}$ 
A concessão de altares móveis também foi outra estratégia para consolidar a penetração nos sertões. Em 1762, ao visitar o descoberto de Cabo Verde, o vigário de Ouro Fino comunicou ao bispo de São Paulo sobre o crescimento da população daquele arraial, julgando ser necessária maior assistência religiosa. Este determinou então, com provisão passada no mesmo ano, levantar altar portátil, administrar os sacramentos e benzer o cemitério do novo descoberto. Segundo Almeida, "o altar portátil era a forma acertada da penetração da lgreja Católica em territórios recém-ocupados; por meio dele, o capelão celebrava a missa cotidiana ou domingueira". ${ }^{150}$ De acordo com a autora, diversos documentos mostram a necessidade de concessão de altares móveis como meio de administrar os sacramentos, diminuindo o trabalho de deslocamento dos párocos pelas fazendas e outros pontos urbanizados. Como bem lembra Andrade:

costume dos sertanistas-descobridores das Minas do ouro, notadamente paulistas, de apresentarem-se como devotos católicos no sertão, levando capelães nas entradas ou instituindo lugares sagrados, relacionava-se às suas obrigações de reduzir ou manter os índios ao cristianismo, legitimando a administração destes trabalhadores, e às disposições tradicionais de recomendar os descobertos às próprias invocações de santos. ${ }^{151}$

\section{Descoberto do rio Pardo}

A capitania de São Paulo foi restaurada em 1765, tendo como governador D. Luís Antônio de Souza Botelho Mourão (o Morgado de Mateus). No período de seu governo, entre 1765 e 1775, houve incremento na fixação da população nos sertões paulistas, 152 expressando uma estratégia da metrópole portuguesa na defesa de seus territórios, em contraposição aos conflitos internos e às disputas com os domínios coloniais de Espanha. ${ }^{153}$ As iniciativas desse período fazem parte das reformas iluministas do primeiro-ministro Sebastião José de Carvalho e Melo, o Marquês de Pombal, tema que já foi explorado em estudos precedentes. ${ }^{154}$

Uma das questões tratadas logo no início do governo do Morgado de Mateus foi a posse dos "novos descobertos do Rio Pardo situados a oeste do rio Sapucaí, junto ao caminho de Goiás" - N. Sra. da Conceição do Desemboque, Jacuí e Cabo Verde. ${ }^{155}$ Ivone Salgado e Renata Baesso Pereira nos esclarecem que, em agosto de 1765, o então governador de Santos, Alexandre Luiz de Souza Menezes, enviou uma carta ao Morgado de Mateus informando sobre os descobertos auríferos feitos desde a Campanha do Rio Verde, na região do Sapucaí; sobre as divisas adotadas, em 1749, por Thomas Ruby de Barros Barreto; ${ }^{156}$ e sobre a situação das minas
150. Almeida, op. cit., p. 91.

151. Andrade (2008, p. 1).

152. Embora não seja objeto deste trabalho, é necessário mencionar que a política urbanizadora do governo de Morgado de Mateus não se restringiu à ocupação dos sertões. Suas ações incluíram o incremento para a produção de açúcar na capitania de São Paulo - até então pouco povoada - e eram voltadas ao comércio metropolitano; a ocupação da região sul da colônia, em torno do Caminho do Viamão, e a delimitação ocidental da capitania de São Paulo, com a fundação da Fortaleza de N. Sra. dos Prazeres do Iguatemy. Há de se destacar também o esforço de reorganização militar na capitania em torno das Companhias de Ordenanças, por meio do recenseamento da população de todo o território, a partir de 1765 - os censos populacionais, conhecidos como "Maços de População", inaugurados em 1765 em São Paulo, constituem uma série documental única devido ao período abrangente e aos dados compilados (BACELLAR, 1997). Mostra, portanto, uma intenção de organizar a população para o serviço militar, além do controle da produção de açúcar e gêneros de subsistência em toda a capitania. De acordo com Ivone Salgado e Renata Pereira (2017b, p. 2), a política pombalina "teve como principais ações o fortalecimento do poder da Coroa contra alguns interesses do catolicismo jesuítico e da nobreza, através da expulsão dos religiosos da ordem dos domínios portugueses e da extinção das donatarias; a definição e preservação das fronteiras brasileiras a partir da ocupação da hinterlândia por um sistema de cidades, vilas e povoações; e a transferência do Governo Geral 
do Brasil de Salvador para São Sebastião do Rio de Janeiro em 1763".

153. Derntl (2010, p. 2).

154. Cf. Derntl (2010) e Bellotto, op. cit.

155. Derntl (2013, p. 130131).

156. Salgado e Pereira (2017a, p. 232).

157. Documentos interessantes para..., op. cit., p. 98.

158. O Registro de Itupeva localizava-se na passagem do Caminho dos Goiases no córrego de mesmo nome, assinalado nos mapas do século XVIII como "Itapeva", "Itupeva" ou "Itubeba".

159. Documentos interessantes para..., op. cit., p. 98.

160. Cf. Fridman (2011).

161. Campanhole, op. cit., p. 59.

162. Documentos interessantes para..., op. cit., p. 29

163. Campanhole, op. cit., p. 129, grifos nossos.

164. Ibid., p. 130. chamadas Desemboque - "que comprehende os Arrayaes de Santa Anna, São Pedro de Alcantara, São João do Jacuí, e Asumpção de Cabo Verde"157 - que foram empossadas pela comarca de São Paulo. Segundo o governador de Santos, essa situação não se manteve, pois em 1764 o governador de Minas, D. Luiz Diogo Lobo da Silva, fez uma nova divisão na qual os descobertos do Desemboque e as paróquias antes providas pelo bispado de São Paulo passaram a pertencer à capitania de Minas e ao bispado de Mariana.

Em 20 de agosto de 1765, o comandante do registro de Itapeva, ${ }^{158}$ Jerônimo Dias Ribeiro, informou ao governador de Santos que havia descobertos de novas minas de ouro "nas cabeceiras ou vertentes do Rio Pardo, que banha a estrada que desta Cidade segue para Goyaz". ${ }^{159}$ Esse novo descoberto reavivou as discussões sobre os limites das capitanias e, a partir de então, correspondências foram trocadas entre o Morgado de Mateus e outros "funcionários régios"160 sobre a posse desse novo descoberto.

As primeiras notícias do descoberto de N. Sra. da Conceição, posteriormente denominado de descoberto do Rio Pardo foram dadas no início do governo do Morgado de Mateus, em 1765. Para Adriano Campanhole, esse descoberto estava localizado no rio Bom Sucesso, afluente do rio Pardo, a quatorze quilômetros do centro da atual cidade de Caconde, São Paulo. 161 Para o governo da capitania de São Paulo, a questão principal era determinar se os novos descobertos estavam dentro dos limites traçados pela linha de Thomas Ruby, em 1749. É importante observar que, no mapa representando o "giro" de D. Luiz Diogo Lobo da Silva (Figura 7), de 1764, não é indicado o descoberto do rio Pardo, pois é posterior a essa data e não foi aposseado pelo governador de Minas naquela ocasião.

Esses descobertos são mencionados logo na introdução do volume XI dos Documentos Interessantes para..., por Orville Derby: "Achavam-se situadas nos valles de diversos tributários que para o Rio Pardo descem do espigão entre Jacuí e Cabo Verde, no distrito que desde aquele tempo tem conservado o nome de Caconde". ${ }^{162}$

A região recebeu o nome de "Caconde", pelo qual ainda é conhecida. Essa toponímia tem raízes tanto indígenas como africanas, como nos esclarece Adriano Campanhole: "João Mendes de Almeida, no seu 'Dicionário Geográfico da Capitania de São Paulo', ao anotar a expressão Caconde, diz que a mesma é corruptela de qua-quéo-nd-e; quebrada bem notável por onde passam muitos". ${ }^{163}$ Sobre a origem africana do nome, Campanhole ainda afirma que "Caconda era uma povoação da África Portuguesa Ocidental, presídio e capital do Conselho de Caconda. Foi fundado o presídio por volta de 1682 por João da Silva e Souza, governador de Angola". 164 nome teria sido atribuído à região do descoberto em razão das populações quilombolas existentes, formadas pelos negros "cacundas". Nelson de 
Senna afirma que o topônimo é de origem africana, "relembrando Caconda, na África Ocidental e que teria dado a palavra Cacunda, também usada no Brasil, no lugar de 'dorso' ou 'costas'". 165 Também apresenta a hipótese de a palavra derivar do indígena cáa-co-ndê, significando "é tua esta mata?". 160

As primeiras providências para controlar a região dos novos descobertos foram tomadas em 1765. Ignácio da Silva Costa ${ }^{167}$ partiu de Santos em direção ao descoberto do Rio Pardo, e em carta de 15 de maio de 1765 informou ao Morgado de Mateus:

Ontem que se contaram 14 do corrente, cheguei a esse registro de ltapeva, tendo-se-me pelo caminho noticiado que o descoberto do Rio Pardo estava deserto por não fazer conta aos mineiros que para ele tinham entrado, por faltar o ouro; a respeito do que me diz o sargento Jerônimo Dias, terem saído não tanto por essa causa, como por não haver ali quem repartisse as terras, para o que espera agora das Gerais o superintendente ou seu substituto. Daqui para o Descoberto não há caminho; pelo que é preciso ir buscá-lo quatro léguas antes do Arraial do Emboque, o qual dista deste sítio, e sertão deserto, treze dias, que tantos gastaram os do Emboque, quando foram tomar a sua posse por parte das Gerais. ${ }^{168}$

"Arraial do Emboque" era a denominação adotada para a freguesia de Jacuí (1762), chamada também de Arraial de São Pedro e Almas do Emboque. ${ }^{169}$ Na carta mencionada é descrita a situação dos caminhos até o descoberto do rio Pardo, em 1765: não havia caminho direto até a região; era necessário subir pelo Caminho dos Goiases até Jacuí para depois descer novamente e alcançar a região do novo descoberto. Essa configuração espacial é visível no mapa da Figura 3.

A posse do descoberto do Rio Pardo foi feita em 2 de outubro de 1765. $\bigcirc$ documento foi localizado no acervo digital da Biblioteca Nacional ${ }^{170}$ e ainda não havia sido explorado em estudos anteriores. $\bigcirc$ jornalista e escritor Adriano Campanhole foi quem mais avançou na pesquisa sobre o descoberto do rio Pardo e a fundação de Caconde, nos indicando a possível existência desse documento: 171

Auto de posse deste novo descuberto de Nossa Senhora da Conceicam da Capitania da cidade de Sam Paulo.

Anno do Nascimento do Nosso Senhor Jesus Cristo de mil e setecentos e cecenta e sinco aos dois dias do mês de outubro do ditto ano nesse novo descuberto de Nossa Senhora da Conceicam da Capitania e Comarca da Cidade de Sam Paulo aonde foram vindos o Capitam Ignácio da Silva Costa por ordem e em nome do Illustríssimo e Excelentíssimo Senhor Dom Luiz Antonio de Souza Botelho Mouram governador e capitam general da citta capitania, Juiz Presidente e mais oficiais da câmara da villa de Jundiaí da ditta Comarca,
165. Senna (1924, p. 285).

166. Ibid., p. 285.

167. Ignácio da Silva Costa, Capitão de Infantaria da Praça de Santos (1762), foi o primeiro Comandante do Descoberto do Rio Pardo (CAMPANHOLE, 1979, p. 61).

168. Documentos interessantes para..., op. cit., p. 88 .

169. Campanhole, op. cit., p. 55 .

170. Cf. Carta de posse..., 1765.

171. Nas palavras do autor, "foi sem dúvida em outubro que se efetuou, por parte de São Paulo, a posse do Descoberto do ribeirão do Bom Sucesso. Por mais que pesquisássemos não encontramos o auto respectivo" (CAMPANHOLE, 1979, p. 63). 
172. Carta de posse... op. cit., grifos nossos.

173. Derntl (2013, p. 130).

174. Um aviso régio de 4 de fevereiro de 1765 ordenava o auto de demarcação, mencionando o "o miserável estado a que se achava reduzida a Capitania de S. Paulo por falta de governo, e do novo descuberto de S. João de Jacuí, que fica muito perto da cidade de S. Paulo" (Documentos interessantes para..., op. cit., p. 211).

175. Derntl (2010, p. 121).

176. Documentos interessantes para..., op. cit., p. 211-227. com mesmo Tabelliam [...] do judicial de Nossas [...] ao deante nomeado para efeito determos posse pessoal e judicial destas terras minerais do ditto descuberto nas agoas vertentes, e mais pertencentes deste continente, [...] no mesmo exercício, exceto da dita posse foy esta apregoada por Eum mulato [...] por nome José Pereira o qual em alta voz clara [...] legível que de todos bem [...] apregoou dizendo posse posse posse que tomam o Capitam de Infantaria Ignácio da Silva Costa por ordem e em nome do Illustríssimo e Excelentíssimo Senhor Dom Luiz Antonio de Souza Botelho Mouram Governador e Capitam General da Capitania da cidade de Sam Paulo, adejunto com o Juiz Presidente e mais oficiais da Câmara da Villa de Jundiaí da ditta Capitania destas terras minerais sua agoas e todos os mais pertencentes deste dito descuberto das cabeceiras do Rio Pardo, e córrego do nascente para o poente o qual desagoa em o ditto Rio, com Euma Legoa de [...], entre largo e comprido entre duas cachoeiras que formam o cito córrego, [...] Seoponha ou contradiga esta dita posse [trecho incompreensível] faz embargos ou outra qualquer que ceja que terão para dizer desta, sendo tudo isto assim feito e declarado, correndo por largo espaço de tempo, dentro do qual por nam aparecer sem sequer pessoa alguma que impugnasse ou embaraçasse esta dita posse. Logo eu dito Tabeliam com o dito Capitam [...] mais oficiais passeamos pelas ditas terras, entramos pelo ditto córrego e nele mandando louvar [...] pegamos em terra e lançamos ao ar e fazendo uma Cruz a levantamos ao alto e assim se fizeram judicialmente todos os actos possessórios pelos quais nos demos por nossa posse dos descobertos mencionados de posse pessoal, judicial manca e pacificamente sem oposicam nem contradicam de pessoal alguma. ${ }^{172}$

documento revela características semelhantes àquelas dos autos de posse de Jacuí (1755) e Desemboque (1761), analisados anteriormente. A posse do descoberto de N. Sra. da Conceição também foi feita em nome da comarca de São Paulo e do conselho da Vila de Jundiaí. As toponímias "descoberto" e "continente" novamente aparecem para designar o local onde se encontravam as minas de ouro e as regiões circunvizinhas. $\bigcirc$ ritual consistiu também em levantar o símbolo da cruz e apregoar um documento proferindo repetidas vezes a palavra "posse", feito sem contradição ou oposição dos presentes. A região das "Cabeceiras do Rio Pardo", como indicado no documento citado, referia-se aos afluentes do rio Pardo na região dos novos descobertos - rios Bom Sucesso e São Mateus.

De acordo com Derntl, uma das incumbências do Morgado de Mateus era tratar dos limites da capitania. ${ }^{173}$ As discussões, que haviam se iniciado em fevereiro de 1765, 174 foram retomadas em outubro do mesmo ano, quando foi instituída uma junta pelo vice-rei, conde de Cunha, no Rio de Janeiro, para tratar do assunto das divisas entre as capitanias de São Paulo e Minas Gerais. ${ }^{175}$ Seguiram-se correspondências aos governadores de São Paulo e Minas Gerais ${ }^{176}$ e, em 12 de outubro de 1765, a junta reunida no Rio de Janeiro estabeleceu como divisa das capitanias o rio Sapucaí. A posse do descoberto do rio Pardo, feita pouco tempo antes, influenciou diretamente as negociações pela divisão das capitanias que privilegiavam o governo de São Paulo. Segundo Bellotto, a 
posição do Morgado de Mateus, à época, era de que a demarcação deveria ser feita em função dos novos descobertos de ouro. ${ }^{177}$

No entanto, como afirma Fonseca, os governadores de Minas não acataram a decisão do Conde de Cunha e continuaram a expandir as fronteiras, contando com discreto apoio da Coroa, visto que essa ampliação acarretava vantagens fiscais. ${ }^{178} \bigcirc$ Morgado de Mateus continuaria, até o final de seu governo, a reivindicar a divisão de 1765 pelo Sapucaí, enviando correspondências e cartas geográficas a Lisboa. ${ }^{179}$

Após a posse do descoberto do rio Pardo e da divisão das capitanias pelo rio Sapucaí, em 1765, uma das medidas do Morgado de Mateus foi ordenar a abertura de um caminho que ligava o novo descoberto do rio Pardo ao registro de ltapeva, o mais próximo da região:

Ordem sobre a picada do Descoberto de Conceição para o Registro de Itapeva. Ordeno a lgnacio Cabral da Cunha passe às Freguezias de Mogiguassú, e mirim, e nellas notifique e alliste, a minha Ordem, todos os Capitães do mato, e mais pessoas dezimpedidas de que necessitar, para effeito de poder hir endireitar a picada que sahe do Descuberto de N. Senra. da Conceição para o Registo de Itapeva, e para outras mais diligencias que se offerecerem do Serviço de S. Magestade, para as quaes dou faculdade ao dito Ignacio Cabral da Cunha para os poder dominar, e os mesmos noteficados serão obrigados a obedecer-the, e se algum the não quizer obedecer no que o mesmo thes ordenar: $\bigcirc$ Capitão Manoel Rodrigues de Araujo Belem, a quem mando ordem a este respeito, o mande logo prender, remeter á minha presença para ser castigado a meu arbítrio. Santos a 28 de Janeiro de 1766. D. Luiz Antonio de Souza. ${ }^{180}$

A posse do novo descoberto despertou interesse por parte de Minas Gerais e, a partir da tomada de posse pelo governo paulista, uma grande correspondência começou a ser trocada entre os dois governadores. Sobre essa disputa territorial, o vice-rei, conde de Cunha, enviou correspondência de 2 de dezembro de 1765 ao governador Morgado de Mateus ordenando que:

Devo dizer a V. Exa. que enquanto eu não decido esta importante matéria, que Sua Magestade me tem recomendado, deve $V$. Exa. não alterar cousa alguma, e fazer todo o possível para que em boa união e sossego, se conservem os povos, sobre que pende a dita decisão. ${ }^{181}$

A ordem vinda do governo em Lisboa e adotada pelo Morgado de Mateus foi realizar o impedimento do descoberto. Essa comunicação foi feita em carta ao governador de Minas, de 10 de fevereiro de 1766. Procede então o governador de São Paulo a colocar uma guarda próxima da região, realizando
177. Bellotto, op. cit., p. 81. 178. Fonseca, op. cit., p. 201.

179. Em correspondência da Junta de Administração e Arrecadação da Fazenda Real da Capitania de São Paulo, de 12 de janeiro de 1773, enviada ao rei D. José I, D. Luiz Antônio de Souza discorre sobre os desentendimentos entre as duas capitanias. O governador paulista pede que o rei observe o assunto da divisão dada pela junta do Rio de Janeiro em 12 de outubro de 1765 , convocada pelo vice-rei, conde de Cunha. Anexa à correspondência está a cópia do assento que modificava, portanto, a divisão feita pelo ouvidor da comarca do Rio das Mortes, Thomas Ruby de Barros Barreto, estabelecendo a divisa das capitanias pelo rio Sapucahy. O mapa (apresentado na Figura 1) acompanhou essa documentação e mostra as reivindicações do Morgado de Mateus buscando questionar as campanhas de conquista do governo de Minas Gerais, especificamente o "giro" de D. Luiz Diogo em 1764, responsável por tomar posse das paróquias instituídas por paulistas em Jacuí, Cabo Verde, Ouro Fino e Itabujá. Cf. Carta da Junta..., 1773.

180. Documentos interessantes para..., op. cit., p. 97.

181. Ibid., p. 257. 
182. Uma interpretação pertinente desse mapa foi feita por Piccinato Junior (2012, p. 87), que demonstra a localização dos sete marcos divisórios das sucessivas demarcações de fronteiras.

183. Derntl (2013, p. 130).

184. Documentos interessantes para..., op. cit., p. 173-174.

185. Cf. Campanhole, op. cit. 186. Ibid., p. 80
- impedimento do descoberto e da repartição de datas minerais. A "Carta Corográfica dos limites do Estado de Minas Gerais com o de São Paulo" IFigura 7) foi elaborada em 1766 no contexto das discussões em torno das delimitações de fronteira entre as duas capitanias: São Paulo deixa claro, por meio de seu governador, D. Luís Antônio de Souza Botelho Mourão, seu descontentamento em relação às divisas civis. $\bigcirc$ mapa, de forte discurso político, representava o descoberto do rio Pardo (Figura 8), alertando, contudo, para a perda de territórios da capitania de São Paulo em relação à capitania de Minas Gerais. ${ }^{182}$

Em 22 de outubro de 1769 a freguesia de Mogi Mirim é elevada à condição de vila de São José de Mogi Mirim, pelo Morgado de Mateus. O termo da nova vila tinha como limite o Rio Grande, e todo o sertão, que antes pertencia à vila de Jundiaí, passava então para a jurisdição da nova vila. Para Derntl, a elevação a vila de Mogi Mirim em 1769 buscou consolidar a ocupação paulista nessa região. ${ }^{183} \mathrm{O}$ fato de o Morgado de Mateus elevar a vila tal povoação refletia também os interesses da políitica pombalina de urbanização por meio da fixação de uma população antes dispersa em sítios volantes. Em correspondência de 27 de junho de 1769 o governador paulista relata:

que era muito convincente ao seu Real Serviço que nessa Capitania se erigissem Villas naquelas partes onde fossem mais convenientes e que a ellas se congregassem todos os vadios e dispersos que vivessem em sítios volantes para morarem em povoações civis, em que se thes pudessem administrar os sacramentos e estivessem promptos para as occaziões do seu Real Serviço. ${ }^{184}$

O impedimento do descoberto do rio Pardo em 1766 e a elevação de Mogi Mirim à condição de vila, em 1769, não acalmaram os ânimos em torno da disputa dessa região de fronteira. $\bigcirc$ governo da capitania de Minas, almejando a posse do dito descoberto, enviou em 1771 uma patrulha do Regimento dos Dragões de Minas Gerais para ocupar o passo do rio Pardo, no Caminho dos Goiases. Esse era o local de passagem do rio onde eram cobradas taxas pelo trânsito, responsabilidade do rendeiro Lourenço Bezerra. ${ }^{185}$ Segundo Campanhole:

Apoderaram-se os soldados das canoas, depredaram as instalações da passagem e colocaram um marco, logo em seguida destruído pelo comandante do registro paulista. $\bigcirc$ próximo objetivo dos dragões, segundo afirmavam, era ocupar a Estrada dos Goiases, até Mogi-Guaçu. D. Luís Antônio de Souza acabou impacientando-se com as contínuas invasões da Capitania. Mandou então ocupar militarmente as terras minerais do Rio Pardo e Jaguari. ${ }^{186}$ 

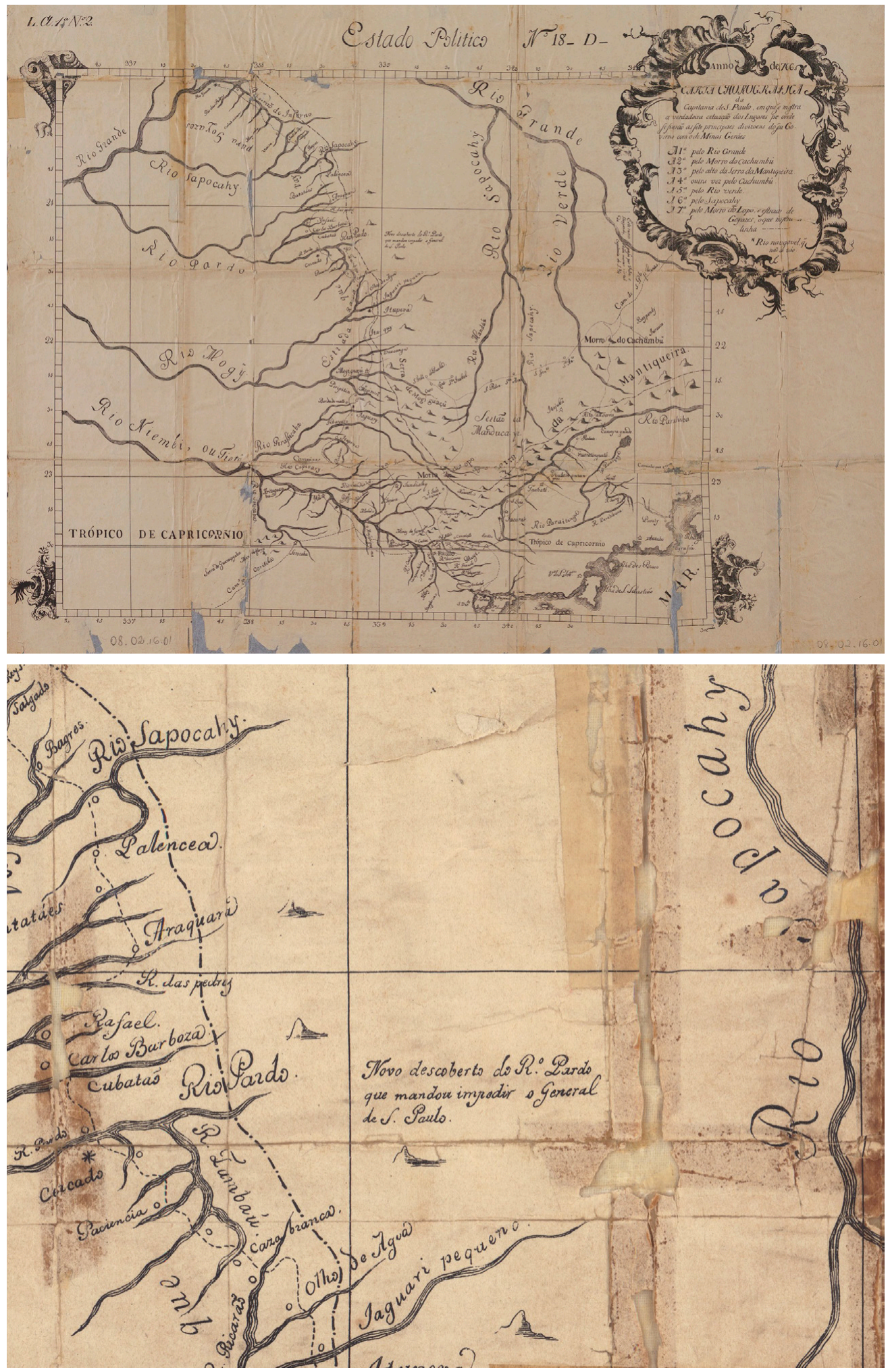

Figura 7 - Carta Chorographica da Capitania de São Paulo em que mostra a verdadeira cituação do Logares por onde se Fizeram as sete principaes divizoens do seu governo com o de Minas Geraes, anno de 1766. Uma outra versão desse mapa, elaborada em 1773, foi apresentada na Figura 1 deste artigo. Fonte: Arquivo Público do Estado de São Paulo. Disponível em: <https://bit. ly/35HJqwl>. Acesso em: 5 maio 2020.

Figura 8 - Detalhe do mapa Carta Chorographica da Capitania de São Paulo... (1766) com destaque para a indicação do "Novo descoberto do R. . Pardo que mandou impedir o General de S. Paulo". Fonte: Arquivo Público do Estado de São Paulo. Disponível em: <https://bit.ly/35HJawls. Acesso em: 5 maio 2020. 
187. Documentos interessantes para..., op. cit., p. 163.

188. Cf. Ferreira, op. cit.

189. Almeida, op. cit., p. 96.
Como consequência desse acontecimento e após o descobrimento das minas na região do rio Bom Sucesso, tributário do rio Pardo, repartiram-se as terras minerais, em 7 de julho de 1772, por meio de carta enviada ao tenente guarda-mor Francisco José Machado pelo Morgado de Mateus. Na ordem de repartição e ocupação das ditas terras consta:

que se devem continuar na repartiçam dessas terras mineraes, segurança dos Reaes Direitos, e conservação da antiga posse dos limites dessa Capitania [...] e de todo movimento, ou novidade que houver por parte de Minas que fação prontos, e claros, avisos. ${ }^{187}$

Em 1765, como parte da estratégia de defesa dos descobertos auríferos e dos limites da capitania, no final do governo do Morgado de Mateus (1775) foi criada a freguesia de N. Sra. da Conceição do Bom Sucesso do Rio Pardo (atual município paulista de Caconde), na fronteira com a capitania de Minas Gerais. ${ }^{188}$ A freguesia de Caconde, como passou a ser conhecida ao final do século XVIII, pertencia ao termo da nova vila de São José de Mogi Mirim. Nesse território, outros núcleos urbanos foram formados a partir de pousos no Caminho dos Goiases.

\section{A FREGUESIA DE NOSSA SENHORA DA CONCEIÇÃO DO BOM SUCESSO DO RIO PARDO}

A elevação do descoberto do rio Pardo à condição de freguesia de N. Sra. da Conceição do Bom Sucesso do Rio Pardo pode ser interpretada como mais um episódio das disputas entre os governos das capitanias e dos bispados de São Paulo e Minas Gerais. Sua elevação, em 1775, deve ser compreendida a partir de sua inserção na conjuntura da posse eclesiástica das paróquias do sul da capitania de Minas Gerais. Como demonstramos, em 1764, durante a diligência do governador D. Luiz Diogo aos Sertões da comarca do Rio das Mortes, houve a posse dos territórios anteriormente instituídos pelos paulistas. A instituição canônica havia sido confirmada pela diocese de Mariana em 1765. ${ }^{189}$ De acordo com Adilson de Carvalho, a restituição dessas igrejas ao bispado de São Paulo ocorreu somente em dezembro de 1775, sob a administração do bispo D. Frei Manuel da Ressureição:

Nessa ocasião já governava o Bispado de São Paulo, D. Frei Manuel da Ressureição, que fora eleito em 17 de junho de 1771 e empossado em março de 1774, e o bispado de Mariana estava sob o governo de um procurador de D. Bartholomeu Manuel Mendes dos 
Reis. Os documentos chegariam à Mariana em outubro e só em dezembro de 1775 seria cumprida a ordem de Mariana para a restituição das igrejas. [...] De 1764 a 1775 os vigários de Cabo Verde foram nomeados pela diocese de Mariana. Nessa mesma ocasião (1775), ou pouco depois, foram nomeados vigários paulistas para Cabo Verde e Ouro Fino, sendo restabelecida a autonomia destas paróquias. ${ }^{190}$

A criação da Freguesia de N. Sr. ${ }^{a}$ da Conceição do Bom Sucesso do Rio Pardo se deu, provavelmente, por volta de março de 1775, data da abertura do Registro Paroquial de Batismos pelo padre Francisco Bueno de Azevedo:

Este livro que há de servir para os assentos dos batizados dos brancos livres, e cativos desta Freguesia de Nossa Senhora da Conceição do Bom Sucesso do Rio Pardo, e vai por mim rubricado com minha rubrica costumada que uso = PFBA - por comição e facoldade que me deu o Exmo. e Rvmo. Bispo Diocesano D. Fr. Manoel da Ressurreição atendendo o mesmo senhor a muita pobreza desta Freguesia e ser eu o primeyro parocho que vim criar esta mesma Freguesia [...] Arrayal do Rio Pardo, 2 de março de 1775. ${ }^{191}$

Vê-se que a criação da freguesia, realizada pelo Bispo de São Paulo, D. Frei Manoel da Ressurreição, em dezembro de 1775, ocorreu antes da posse eclesiástica das paróquias do sul de Minas. A toponímia utilizada no documento, "Arrayal do Rio Pardo", permite pressupor uma ocupação estável, onde já devia haver uma capela. Essa hipótese é sustentada por uma correspondência de 30 de outubro de 1773 do governador D. Luiz Antônio de Souza Botelho Mourão ao presidente do Hospício ${ }^{192}$ de São Bento, da Vila de Jundiaí, pedindo que fosse autorizado o envio do frei João Domingos ao descoberto do rio Pardo para administrar os sacramentos no novo descoberto:

Para o Provincial de S. Bento. Como as occazioens do Real Serviço se multiplicão, não posso dispensar de recorrer a V. R. ${ }^{\text {ma }} p .^{a} q^{\prime}$ se Sirva haver por bem $q$ eu nomee ao R. ${ }^{\circ}$ P. e $^{\circ}$ Fr. João de S. Domingos, assist..$^{\text {te }}$ nesse Hospicio, em q. ${ }^{m}$ concorrem circunstâncias m..$^{\text {to }}$ particulares p. hir administrar os Sacramentos às gentes, q. tem entrando o novo Descuberto do R. Pardo; e porq' este Serviço pode Resultar ao Estado, e ao bem Espiritual das Almas grande utilidade, como se espera, rogo a V. R..$^{\text {ma }}$ por Serviço de S. Mag. ${ }^{\circ}$ o gr. ${ }^{a}$ mandar apromtar com toda a brevidade; $q^{\prime}$ eu de tudo darei p..$^{\text {te }}$ ao R. do P. Provincial, de q. ${ }^{m}$ espero nam deixará de aprovar esta m.a determinação. D. ${ }^{s}$ g. ${ }^{e}$ a V. R. ${ }^{\text {ma }}$ m.an. ${ }^{\circ}$ S. Paulo a 30 de 8br. ${ }^{\circ}$ de 1773 // M. R. Sr. P.e Prezid. e do Hospicio de S. Bento da V.a de Jundiaí // D. Luiz Ant. ${ }^{\circ}$ de Souza Botelho Mouram. ${ }^{193}$

Portanto, pode-se deduzir, pelo documento mencionado, que em 1773 já havia uma ocupação estável no descoberto do rio Pardo, com afluxo de pessoas de outras regiões. Em janeiro de 1773, como demonstramos anteriormente, o
190. Carvalho, op. cit., p. 44.

191. Batizados de Caconde..., op. cit., p. 1.

192. Segundo o dicionário de Raphael Bluteau, "hospício" é "uma espécie de convento pequeno de alguma família religiosa, em que se agasalham os hóspedes da mesma religião, quando passam por algum lugar em que não tem convento em forma" (BLUTEAU, 1728 , v. 4, p. 64).

193. Documentos interessantes para..., 1939, p. 168-169. 
194. Trata-se de uma compilação de dados sobre as "parochias instituídas canonicamente". O livro nos dá a dimensão das paróquias instituídas pelo bispado de São Paulo, que compreendia parte do território dos atuais estados de Minas Gerais e Paraná. Em relação à freguesia de Caconde, não constam informações sobre o ano de sua instituição, apenas indica-se: "consta que foi elevada a curato em 1775" (Livro da Arquidiocese..., 1880-1905).

195. São Paulo, 1888, p. 319-320.

196. Bellotto, op. cit., p. 287. Segundo a autora, a nomeação do novo governador tinha acontecido em junho de 1774. A chegada de Martim Lopes ocorreu, no entanto, um ano depois, em 13 de junho de 1775 . No dia seguinte, tomou posse como governador da capitania, sendo recebido por D. Luiz Antônio em São Paulo. Os sucessores do Morgado de Mateus no governo da capitania foram Martim Lopes Lobo de Saldanha (1775-1782) e Francisco da Cunha e Meneses (1782-1786). Raimundo Chichorro da Gama Lobo (1786-1788), Bernardo José de Lorena (1788-1797), Antônio Manuel de Melo Castro e Mendonça (17971802) e Antônio José da Franca e Horta (1753-1823) também tiveram de lidar com os conflitos de fronteira entre as capitanias de São Paulo e Minas Gerais.

197. Ferreira, op. cit., p. 136-167.

198. Jerônimo Dias Ribeiro realizava a guarda paulista na região. Natural de Mogi-Guaçu, onde se casou em 1768, Jerônimo Dias Ribeiro recebeu a patente de sargento em 10 de outubro de 1758. Foi ainda nomeado para a tropa de Santos, em 29 de março de 1774 ,
Morgado de Mateus enviou correspondência a Lisboa relatando as disputas de fronteiras. Em carta de outubro de mesmo ano o governador recorreu ao poder eclesiástico para marcar a posse paulista na região.

A data da fundação da freguesia tem sido tema de debate desde a publicação da obra de Campanhole, em 1979. Malgrado a falta de documentação eclesiástica comprovando a instituição canônica da freguesia, pelos documentos analisados pode-se deduzir que houve uma ocupação anterior a 1775, na qual poderia haver uma capela. No Arquivo da Cúria Metropolitana de São Paulo localizamos um livro intitulado Livro da Arquidiocese de São Paulo, nº 1, 18801905, que coloca como data de criação da capela curada o ano de 1775. ${ }^{194}$ Sobre esse assunto, consta no Relatório da Província de São Paulo de 1888 que:

\begin{abstract}
É bem difíicil, senão impossível, determinar-se ao certo a data em que fundou-se a primeira povoação no município. Os dados históricos fornecidos pelo livro do tombo e pela tradição levam-nos a crer que, em meados do século XVIII, os exploradores de ouro, vindos de Cabo Verde, província de Minas, assentaram as bases de uma pequena povoação no lugar hoje denominado Bom Sucesso, a 13,2 quilômetros da atual cidade. No ano de 1775, a então freguesia de N. S. do Bom Sucesso do Rio Pardo, foi desmembrada, no que diz respeito à vigaria da vara, da de Mogy-mirim, e, quanto ao parochiato, da de Mogy-guassú, sendo pelo Bispo d. frei Manoel da Ressurreição traçadas as divisas da nova freguesia e comarca da vara. ${ }^{195}$
\end{abstract}

Nossa análise procura dar uma nova interpretação a esse evento de criação de uma freguesia no termo da vila de Mogi Mirim, que pode ser visto como um momento de inflexão na política que vinha sendo adotada até então para a ocupação de regiões de mineração pelo Morgado de Mateus, um derradeiro ato buscando garantir a posse paulista desse território, que antecede sua saída do governo da capitania, em 14 de junho de 1775. ${ }^{196}$ Como vimos, a elevação da vila de Mogi Mirim, em outubro de 1769, marca uma estratégia de controle das fronteiras entre as capitanias por meio da criação de núcleos urbanos, e é posterior à data de posse do descoberto do rio Pardo (1765) e de todas as negociações com a metrópole em torno de seu impedimento. Após a fundação dessa freguesia a toponímia dos sertões do Rio Grande se alterou, quando parte da região passou a ser chamada de sertão do rio Pardo, nome encontrado nos censos populacionais a partir de 1778. 197

Na documentação histórica, as "Cabeceiras do Rio Pardo" eram a região onde se localizava a sede da freguesia de N. Sra. da Conceição do Bom Sucesso do Rio Pardo, cujas divisas foram definidas pelo Bispo D. Manuel da Ressureição, que estabelece como limite oriental da freguesia o registro de São Mateus, pois representava o término da jurisdição paulista da região. ${ }^{198}$ Para além daquela 
localidade, iniciava-se o termo da freguesia de Cabo Verde (1769) que, a partir de 1798, passou a compor o termo da vila de Campanha da Princesa, ligado civilmente ao governo da capitania de Minas Gerais e eclesiasticamente ao bispado de São Paulo. Adriano Campanhole cita o documento que definia as divisas da freguesia:

Dada pelo Bispo Dom Frei Manuel da Ressureição para a freguesia de Nossa Senhora da Conceição do Bom Sucesso do Rio Pardo: do Rio Grande até o Rio Pardo correndo pelas estrada de Goiás, e suas povoações, partindo com as da freguesia de Jacuí, e no Rio Pardo entestando com a freguesia de Mogi-Guaçu, sobre a divisa e demarcação desta freguesia da dita passagem do Rio Pardo estrada de Goiás pelo rio acima até as suas cabeceiras e depois correrá rumo direto até o rio Jaguari-Mirim, ficando todo este dito sertão até o Registro ${ }^{199}$ de São Mateus que confina com os fregueses de Cabo Verde para a Freguesia deste Rio Pardo. 200

O bispo D. Frei Manoel da Ressurreição elaborou, em 1777, um relatório com o título "Relação Geral da Diocese de São Paulo, suas Comarcas, Freguesias, Côngruas, Usos e Costumes". 201 Para Oscar de Figueiredo Lustosa, o documento em questão se enquadra no esquema de exigências e prescrições da Coroa relativas à centralização da administração da metrópole sobre o Brasil, ${ }^{202}$ uma política da segunda metade do século XVIII.

No documento, o bispo D. Manuel da Ressurreição faz um resumo breve e direto sobre o estado das paróquias do bispado. A quadragésima segunda paróquia descrita é a "Povoação do Rio Pardo":

O Vigário desta lgreja hé amovível, porque não hé collada nem tem côngrua na Fazenda Real. O seo Paroco atual, e também Vigário da Vara hé Francisco Bueno de Azevedo, natural desta Cidade [São Paulo], de idade de quarenta e quatro anos. Sabe bastantemente Moral, e hé de bons costumes. As conhecenças e pé de Altar rendem quando muito cem mil réis. Não tem Coadjutor, nem mais Sacerdote algum, com Fregueses distantes da lgreja, quatro e cinco dias de viagem. ${ }^{203}$

No mesmo relatório há informações também sobre a quadragésima primeira paróquia, "Arrayal de Cabo Verde" e sobre a quadragésima quarta, o "Arrayal de Jacuí, no Desemboque", demonstrando que, em 1777, o bispado de São Paulo provia párocos para essa região. A administração eclesiástica do bispo D. Manoel da Ressurreição por vezes entrou em conflito com o governo do Morgado de Mateus. Maria Fernanda Derntl afirma que, logo depois da chegada de D. Manoel da Ressurreição em São Paulo, em 1774, iniciaram-se os embates com o governador. ${ }^{204}$ Segundo a autora, em carta de 1776 a Pombal, o bispo criticou bem como para a Companhia de Ordenanças de Santo Amaro, em 15 de outubro de 1788 (CAMPANHOLE, 1979, p. 139). Foi comandante responsável pela guarda do rio Pardo, em 1772 , onde depois de suas nomeações retornou a esse posto, tendo comandado o registro do rio Pardo, em São Mateus, até o dia em que foi retirado, por volta de 1807 , por motivos de sua velhice. Aparece em várias cartas e documentos como responsável pela guarda e registro do ouro na freguesia de Caconde, sendo sua função fundamental assegurar a posse do dito local.

199. Os registros foram, no período colonial, paragens construídas como entreposto de passagem, onde eram fiscalizados os viajantes. Notadamente em áreas de mineração era cobrado o quinto, imposto correspondente à quinta parte de todo o ouro que circulava nas capitanias. A guarda do registro era determinada a uma tropa de ordenanças, e seu chefe local, o comandante do registro.

200. Campanhole, op. cit., p. 168.

201. Relação geral da diocese... (1898-1999).

202. Lustosa, op. cit., p. 911.

203. Camargo, op. cit., p. 376.

204. Derntl (2013, p. 82). 


\section{Ibid.}

206. Documentos interessantes para..., 1896, p. LXIII.

o desmembramento de paróquias para criação de vilas com pequena população, apontou as grandes distâncias percorridas por curas para atender aos paroquianos e mostrou a inconveniência de se ter clérigos das ordens regulares agindo sem legitimidade como párocos em novas povoações. ${ }^{205}$

A afirmação do bispo de São Paulo parece ir ao encontro da situação que analisamos anteriormente, quando o Morgado de Mateus pediu que o frei João Domingos fosse enviado para servir de coadjutor no descoberto do rio Pardo. A política adotada pelo Morgado de Mateus era a do povoamento enquanto estratégia de defesa e consolidação do território em litígio com a capitania de Minas Gerais, valendo-se de meios que, muitas vezes, estavam em discordância com as autoridades eclesiásticas.

Na região do sertão do rio Pardo, após a criação da freguesia de N. Sra. da Conceição do Bom Sucesso do Rio Pardo, aumentaria o número de caminhos e trilhas abertos em função das novas áreas de mineração, mas também como comunicação entre as duas capitanias. A região de Caconde, segunda freguesia criada no termo da vila de Mogi Mirim, estava nos interstícios entre as rotas, e sua posição foi fundamental para assegurar a posse paulista na região (Figura 9). Orville Derby esclarece sobre a rede:

\footnotetext{
Na ocasião de se estabelecer o convênio havia nas quase desertas regiões limítrofes das duas Capitanias duas estradas que limitavam uma zona larga inabitada, porém destinada infalivelmente a se tornar povoada e cortada por novas estradas transversais. Eram estas a Estrada de Goyas pelo lado paulista e, pelo lado mineiro, as antigas picadas, abertas de novo por Luiz Diogo, do Desenboque por Jacuí, Cabo Verde, Campestre, Ouro Fino e Comandocaia para Santa Anna do Sapucahy. Ligando estas duas estradas através da zona despovoada havia as duas estradas transversais de Comandocaia a Atibaia e São Paulo e de Jacuí à estrada de Goyas no registro paulista de ltupeva, adiante de Mogyguassú. 206
}

As correspondências encontradas nos Documentos interessantes relatam as mais diversas situações envolvendo a disputa pelas terras minerais na freguesia de N. Sra. da Conceição do Bom Sucesso do Rio Pardo, onde podemos perceber as nuances de um conflito que envolvia os termos das freguesias limítrofes entre as duas capitanias, com a divisa civil estabelecida por elas. Em correspondência de 16 de agosto de 1775, endereçada ao governador de São Paulo, capitão general Martim Lopes Lobo de Saldanha, o comandante do registro do rio Pardo queixa-se do vigário da freguesia de Cabo Verde que, por ocasião do falecimento de um mineiro na freguesia de $\mathrm{N}$. Sra. da Conceição do Bom Sucesso do Rio Pardo, convidou o reverendo do arraial 
de Cabo Verde para fazer um "ofício de defuntos". Porém, ocorreu que o vigário mineiro tentou levar o defunto para ser sepultado em Cabo Verde.

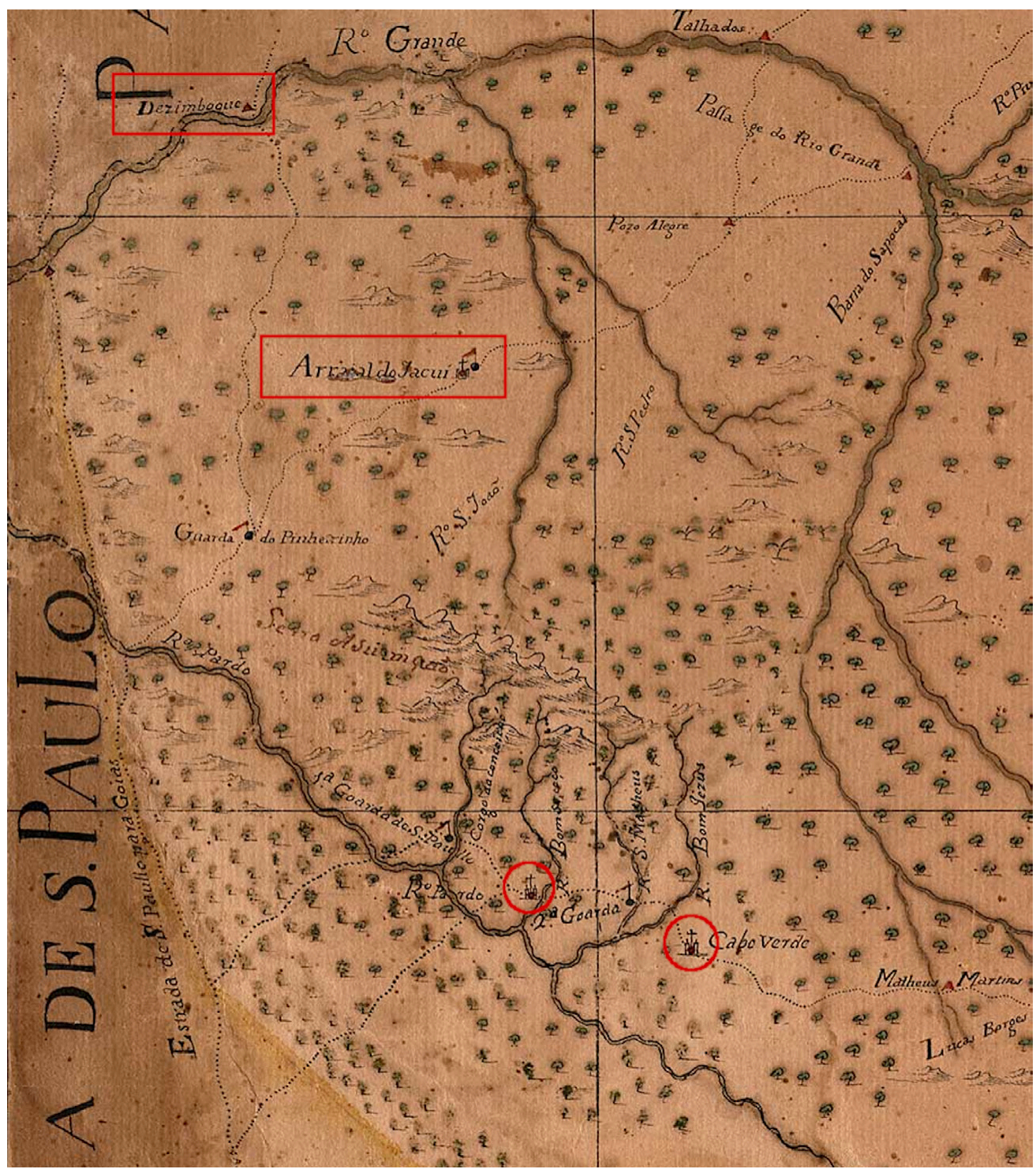

Figura 9 - Recorte do "Mappa da Comarca do Rio das Mortes, pertencente a Capitania das Minas Gerais" (1777) de autoria de José Joaquim da Rocha. Em vermelho estão destacados: o sítio/ fazenda do Desemboque, na passagem do Rio Grande; o arraial de Jacuí, com um destacamento de soldados; a freguesia do rio Pardo e a freguesia de Cabo Verde. Nos caminhos da freguesia do rio Pardo estão representados dois destacamentos de soldados, indicando a localização do primeiro registro e sua transferência para o Ribeirão São Mateus. A legenda do mapa indica, além dos destacamentos de soldados, sítios ou fazendas (triângulo vermelho) e as "paróchias" (símbolo da capela com uma cruz). Disponível em: <http://bit.ly/2RUCSFt>. Acesso em: 19 maio 2020. 
207. Ibid., p. 314-315.

208. Andrade (2008, p. 3).

209. Carvalho, op. cit., p. 43-44.

210. Rocha (1995).

211. Cf. Furtado (2009).

212. De acordo com Júnia Ferreira Furtado, as três memórias escritas por Joaquim da Rocha, em 1778, 1783 e 1788, guardavam muitas semelhanças no conteúdo. A segunda memória, intitulada Geografia: a descrição geográfica, topográfica, histórica e politica da capitania das $\mathrm{Mi}$ nas Gerais, e a terceira, Memória Histórica da Capitania de Minas Gerais, em pouco diferiam do primeiro texto, publicado em 1778 , salvo pequenas modificações e atualizações. Apesar do tom laudatório, exaltando as realizações de governadores, tais memórias serviram, sobretudo, para instrumentalizar os novos governantes das Minas, reunindo não somente descrições históricas, mas "um conjunto notável de documentos - listas de impostos, mapas de população, tábuas de ofícios, folhas de despesa dos ofícios, folhas eclesiásticas, relação de paróquias, entre outros. As informações estavam sistematizadas por vilas ou comarcas, permitindo, ao governador recém-chegado, uma visão integral das Minas Gerais (ou em partes), o que em muito facilitaria suas futuras ações" (FURTADO, 2009, p. 164).

213. Rocha, op. cit., p. 91-95.
Dou parte a V. Exa., que a quatro de Junho faleceu nesse descoberto hum Mineiro, por nome Antônio de Andrade, freguez dessta freguezia e querendo o Rvdo. Padre fazer um Officio de defuntos convidou ao Vigário do Arrayal de Cabo Verde, para vir a esta Freguezia no dia cinco [...] agora novamente diz o Padre Vigário do dito Arrayal de Cabo Verde, que tem ordem do Illmo. Cabido de Minas para vir a este descoberto prender o Rvdo. Vigário, e botar abaixo a igreja. Isso é, o que a este respeito tenho de dar parte a V. Exa., que Deus Guarde. Registro do Descoberto de N. Senhora do Bom Sucesso das cabeceiras do Rio Pardo a 16 de agosto de 1775 - Jerônimo Dias Ribeiro. ${ }^{207}$

Sobre esse evento, é pertinente a afirmação de Andrade em relação às sobreposições de jurisdições civis e eclesiásticas, de que

ao longo do século XVIII, uma outra fonte de conflitos era a concorrência de párocos providos por bispos que, junto com as autoridades leigas, disputavam o poder jurisdicional sobre o sertão das Minas, ou seja, espaços sem jurisdição definida ou polêmica. Isso porque, cada vez mais o que estava em jogo eram os autos emolumentos em ouro cobrados pelos padres aos fiéis, principalmente em locais que tivessem lavras lucrativas de minerais preciosos ou fossem ligados às minas de comércio clandestino. ${ }^{208}$

Comandante da guarda do rio Pardo, Jerônimo Dias Ribeiro, havia recebido ordens do governador de São Paulo para não deixar passar "pessoa alguma de qualquer localidade", em carta assinada, de 6 de julho de 1775, pouco tempo antes do incidente com o vigário de Cabo Verde. A disputa deu-se em relação à freguesia de Cabo Verde, que estava, naquela data, sob a jurisdição do bispado de Mariana. Por isso a intenção do padre mineiro de levar o defunto e mandar derrubar a igreja na paróquia de N. Sra. da Conceição do Bom Sucesso do Rio Pardo. As igrejas seriam restituídas ao bispado de São Paulo em dezembro de 1775 pelo bispo D. Manuel da Ressureição. ${ }^{209}$

Entre 1778 e 1780, José Joaquim da Rocha elaborou a primeira de suas três memórias históricas da capitania de Minas Gerais, Geografia histórica da capitania de Minas Gerais (c. 1778-1780),210 dedicada a D. Rodrigo José de Meneses, governador mineiro recém-empossado. Essa memória histórica, quando lida em conjunto com os cinco mapas produzidos pelo cartógrafo entre 1777 e 1779,211 permite novas interpretações, complementando as informações cartográficas com diversos dados da administração colonial nas Minas. ${ }^{212}$

Nessa publicação, José Joaquim da Rocha reproduz a "Folha eclesiástica do ano de 1778",213 listando as paróquias pertencentes a diferentes bispados e às comarcas mineiras. Vemos que, no bispado de São Paulo, três paróquias pertenciam à comarca do Rio das Mortes e ao termo da vila de São João del 
Rei: Santana do Sapucaí, Nossa Senhora da Conceição do Cabo Verde e S. Pedro de Alcântara de Jacuí. ${ }^{214}$

ao lés-noroeste desta, em distância de cinco léguas, colocaram os moradores de São Paulo uma capela com o título de Freguesia do Rio Pardo, trabalhando aí pelo exercício de minerar e fazer conduzir o ouro que extraem para aquela capitania para o que mandou o governador dela, guardas, que impedem o transporte do mesmo ouro para as Minas, a cuja Capitania pertencem as terras e lugar donde ele se extrai; e as ditas guardas se acham situadas, a primeira, nas margens ocidentais do Córrego do Conceição e a segunda, a Oriente daquela, em distância de seis léguas, situada também nas margens ocidentais do Córrego de São Mateus. ${ }^{215}$

Do mapa da capitania de Minas Gerais (1778) é possível deduzir que o governo mineiro tomava, como divisa da capitania de Minas com a de São Paulo, a antiga demarcação de Thomas Ruby, de 1749, que passava pelo Caminho dos Goiases (Figura 9). Acreditamos que, por esse motivo, a "Freguesia do Rio Pardo" tenha sido descrita na sequência da explicação das freguesias que compunham a vila de São João del Rei, em $1778 .{ }^{216}$ Como comentamos anteriormente, a divisa pelo rio Sapucaí, em 1765, não foi respeitada.

Segundo Carolina Farnetani de Almeida,

Na administração de Francisco da Cunha e Menezes e de Francisco José Raymundo Chichorro da Gama Lobo (1782-1788), as autoridades de Cabo Verde abriram um caminho até o Rio Pardo e tentaram apoderar-se das minas neste rio e nos campos da serra de Caldas, porém foram barradas pelo vigilante comandante do registro de São Matheus. As autoridades de Ouro Fino trataram de estabelecer guarda e registro nos mesmos campos. ${ }^{217}$

Em carta de 21 de abril de 1777, D. Antônio de Noronha, então governador da capitania de Minas Gerais, ${ }^{218}$ queixou-se para o governador de São Paulo sobre a "vexação" causada aos moradores da freguesia de Cabo Verde pelo comandante da guarda posta no ribeirão de São Mateus. ${ }^{219}$ A carta ainda informou que a resolução sobre a divisão das capitanias, por parte de Sua Majestade, "ainda pende decisão". $220 \bigcirc$ governador de São Paulo, Martim Lopes Lobo de Saldanha, em carta de 5 de junho de 1777 ao governador de Minas Gerais, respondeu defendendo-se das acusações dos moradores de Cabo Verde 221 e acusou o governador de Minas por cobrar a derrama de "mineiros estabelecidos nas terras de minha jurisdição [São Paulo]". 222
214. Ibid., p. 95.

215. Ibid., p. 125, grifos nossos.

216. Ibid., p. 125.

217. Almeida,op. cit., p. 63.

218. O governo de D. Antônio de Noronha, na Capitania de Minas Gerais, estendeu-se de 1775 a 1780 .

219. Documentos interessantes para..., 1896, p. 344.

220. Ibid., p. 344.

221. "Se o commandante do Registro de S. Matheus se opoz de alguma parte aos intentos dos dous Mineiros, que recorrerão ao Tribunal da Junta, foi por intentarem estes, em prejuízo dos Reaes Quintos desta Capitania, estender as suas lavras além dos limites que se achão prescriptas até decisão de Sua Magestade" (Documentos interessantes para..., 1896, p. 345).

222. Ibid., p. 345. 
223. Ver mapa da Figura 9.

224. Documentos interessantes para..., 1896, p. 347.

225. Campanhole, op. cit.

226. Ibid., p. 111.

227. "Itaupabas" ou "itaipavas" significa em tupi "rocha por onde passam águas", espécie de recife que atravessa um rio de lado a lado, tornando-o atravessável (CAMPANHOLE, 1979, p. 112).

228. Ibid., p. 115.
Pela Memória de José Joaquim da Rocha (1778) pode-se deduzir também que as guardas militares diferiam dos registros. ${ }^{223} \bigcirc$ registro na região veio a se estabelecer no Ribeirão São Mateus, informação relatada em uma carta do governador Martim Lopes Lobo de Saldanha, de 6 de fevereiro de 1778, ao governador de Minas Gerais, D. Antônio de Noronha. Nela, o governador paulista falou sobre os extravios de ouro que ocorriam na estrada de Jacuí, "em dar entrada no novo registro de São Matheus, para onde fiz mudar o antigo do Rio Pardo, em atenção ao bom cômodo dos viajantes". 224

O registro e as duas guardas militares foram pontos de tensão entre as duas capitanias. Em jogo estavam a cobrança de impostos, a posse das terras minerais na freguesia de N. Sra. da Conceição do Bom Sucesso do Rio Pardo e a expansão dos limites, ainda sem resolução definitiva.

A sobreposição entre os governos civil e eclesiástico na região contribuía para acirrar as disputas. Como vimos, Jacuí e Cabo Verde eram paróquias pertencentes ao bispado de São Paulo, mas civilmente ligadas à capitania de Minas Gerais. A presença de guardas militares e registros nessa fronteira também revela uma região em constante tensão, passível de invasões e descumprimentos por parte dos dois governos. No início da década de 1780 o governador de São Paulo, Martim Lopes Lobo de Saldanha, havia fechado outros caminhos que ligavam a capitania com a de Minas Gerais, na intenção de obrigar a passagem pelo registro de São Mateus. Segundo Adriano Campanhole, a medida não obteve os resultados desejados, uma vez que os mineiros percorriam o caminho de Cabo Verde até a região de Caldas, alcançando o registro existente em Ouro Fino, para, em seguida, atravessarem a fronteira na região de Mogi-Mirim. ${ }^{225}$

Em 1781 novos descobertos de ouro foram feitos na barra do rio Bom Jesus, afluente do rio Pardo, pelo alferes Inácio Preto de Moraes. ${ }^{226}$ Sua nomeação como alferes da Companhia de Ordenanças da freguesia de Mogi-Guaçu da vila de Jundiaí deu-se em 17 de março de 1768, ou seja, antes mesmo da criação da vila de Mogi-Mirim. A posse do descoberto, feita por Inácio Preto de Moraes, deu-se em 1782, pelo vigário Bueno de Azevedo, nos "barrancos e itaupabas ${ }^{227}$ do rio Pardo, na barra do Ribeirão chamado Bom Jesus". ${ }^{228}$ Adriano Campanhole transcreveu o auto de posse dos novos descobertos, cujo original encontra-se na Cúria Metropolitana de São Paulo. que toma posse o Senhor Vigário da Vara Francisco Bueno de Azevedo, por ordem do Exmo. Rvmo. Senhor Dom Frei Manuel da Ressurreição, Bispo de São Paulo, dos barrancos, e Itaupabas de uma e outra parte, rio abaixo, rio acima, e pelas barrancas do rio Pardo, 
barra do Ribeirão do Bom Jesus, e na minha presença, e das testemunhas, mais o povo fez o dito senhor aquelas cerimônias. ${ }^{229}$

Podemos afirmar que a fundação da freguesia de N. Sra. da Conceição do Bom Sucesso do Rio Pardo (Caconde) teve um aspecto estrutural na rede urbana em formação, pois sua posição estratégica na região de fronteira foi um dos instrumentos para assegurar a posse paulista na região. Logo no início do governo do Morgado de Mateus ocorreu a elevação da vila de Mogi Mirim (1769), que representava uma nova jurisdição sobre o sertão do rio Pardo e sobre os novos descobertos que levavam seu nome. A ação do Morgado de Mateus era clara: ao criar uma vila, um novo termo, aproximava a jurisdição da Coroa dos novos descobertos e, na perspectiva de uma "cidade difusa", ${ }^{230}$ ali estavam fragmentos de urbanidade que representavam a autoridade da capitania de São Paulo e da Coroa portuguesa. A fundação de Caconde não pode ser vista em separado dessa lógica: a criação da freguesia, em 1775, foi um último esforço do Morgado de Mateus para assegurar a posse da fronteira em razão dos recorrentes conflitos e pressões estabelecidos pelos mineiros. A definição do termo da freguesia de Caconde pôde levar as autoridades civis e religiosas para o centro dos conflitos e, em uma tentativa de ordenamento desse sertão, conferir à região um registro que pudesse fazer a guarda militar e aplicar as ordens do governo de São Paulo.

\section{CONSIDERAÇÕES FINAIS}

O processo histórico de ocupação da hinterlândia na América lusoespanhola e de sua incorporação ao espaço colonial português envolveu um jogo complexo, com diversos movimentos simultâneos, agentes sociais e escalas. Buscamos revelar a complexidade do processo de ocupação dos sertões do Rio Grande, no decorrer do século XVIII, e da formação das redes administrativas civil e eclesiástica a oeste do rio Sapucaí, entre as capitanias de Minas Gerais e de São Paulo. Privilegiamos o estudo das formas de fixação nesse território e das práticas associadas a estas, mostrando um modus operandi de construir o território colonial que envolveu a conquista e subjugação de povos indígenas e quilombolas, a posse e disputa por locais de mineração, a criação de circunscrições judiciárias e o enraizamento de práticas ligadas ao exercício da religião católica. Em uma conjuntura de média duração, revelam-se os projetos 
de colonização na América portuguesa e de expansão da cristandade, viabilizados por movimentos diversos que se confundem e se misturam.

Diante da complexidade imposta à compreensão de todos os movimentos destacados ao longo do texto, adotar diferentes escalas geográficas é um recurso importante para buscar estabelecer relações entre os eventos diversos que ocorreram nos sertões, as circunscrições administrativas civis e eclesiásticas, que impuseram territorialidades por vezes justapostas e conflitantes, além da conjuntura políticoadministrativa desenvolvida na segunda metade do século XVIII. Assim, o método aqui proposto busca reunir e organizar, sob uma visão de conjunto, eventos aparentemente desconexos, identificados na documentação textual do período. A complexidade dos movimentos e das relações entre os agentes supracitados revelouse também na estrutura deste trabalho, que não adota uma narrativa linear. A partir da narrativa construída, novas interpretações são possíveis, ressignificando, inclusive, a importância dos pequenos núcleos e agrupamentos humanos na rede urbana, mostrando que, malgrado não possuíssem status de freguesias e vilas, foram fundamentais na definição da posse e do que se entendia pelo território das capitanias de Minas Gerais e São Paulo. A posse dos descobertos de Jacuí, Desemboque e do Rio Pardo, e a posterior elevação desses núcleos de povoamento à condição de freguesias, julgados e vilas, são eventos ligados ao projeto de estruturação do território das capitanias, em constante conflito.

O caráter de imprecisão dos limites e das circunscrições territoriais produziu litígios de fronteiras que repercutiram nas decisões dos governos das capitanias e nas políticas de ocupação dos sertões. Os eventos regionais, que envolveram cerimônias de posse de descobertos, campanhas militares de extinção de quilombos, criação de julgados e a posse eclesiástica de paróquias, repercutiram na geopolítica adotada para a colônia, transformando-se em justificativas utilizadas pelos governadores-generais de São Paulo e Minas perante a corte em Lisboa, a fim de favorecer seus interesses na expansão do território e das políticas tributárias e fiscais. Buscamos lançar luz na interdependência entre as ações tomadas na microescala a partir da definição das estruturas administrativas maiores: capitanias, bispados e comarcas. Assim, as decisões sobre os limites dessas circunscrições refletiram-se nos movimentos de ocupação dos descobertos, arraiais e freguesias, que, por sua vez, influenciaram na definição dessas macroestruturas.

Exploramos com mais detalhes a posse dos descobertos auriferos de Jacuí (1755), Desemboque (1761) e N. Sra. da Conceição do Rio Pardo (1765), analisando, inclusive, um documento inédito sobre este último. Tendo como foco a política empregada pelo Morgado de Mateus, governador da capitania de São Paulo entre 1765 e 1775, demonstramos a importância da fundação da Freguesia 
de N. Sra. da Conceição do Bom Sucesso do Rio Pardo (Caconde) nas disputas de fronteira entre São Paulo e Minas Gerais. A política do governador paulista nesse território envolveu ações em conjunto com o poder eclesiástico para a posse do descoberto do rio Pardo e de sua elevação a freguesia, uma das derradeiras ações de seu governo. $O$ estudo de caso dessa freguesia pode ajudar a compreender melhor o papel desempenhado pelos núcleos urbanos coloniais dentro da conjuntura das políticas lusas para a ocupação do Centro-Oeste da colônia. De um modo geral, o conceito de uti possidetis foi a tonante nas decisões para a posse civil e eclesiástica de descobertos, arraiais e paróquias nos sertões.

Fica evidente, na documentação textual e cartográfica analisada, um discurso de posse das regiões limítrofes, onde havia descobertos de ouro, arraiais e freguesias, mineiras, paulistas e goianas. Nos mapas de José Joaquim da Rocha, feitos entre 1777 e 1778, a mesma intenção transparece com relação ao "Descoberto do Rio Pardo". De fato, os mapas do período serviram como forte argumento no projeto de ocupação do interior da colônia pelos governos das três capitanias.

Importantes pesquisas já estudaram o processo de ocupação dos sertões mineiros, paulistas e goianos e da formação de suas redes urbanas. Utilizamos essas contribuições relacionando os diversos movimentos e apontando conexões ainda não indicadas entre as obras desses autores. $\bigcirc$ campo de pesquisa é fértil em possibilidades, fomentando cada vez mais novas investigações pautadas nos detalhes da pequena escala e no estudo intensivo da documentação primária, o que permitiria incluir novas localidades no processo histórico de construção do território colonial. Futuros desdobramentos dessa pesquisa devem considerar essas conexões regionais, mas também ampliar a perspectiva macroterritorial, de forma a oferecer novas interpretações dos processos e avançar no estudo da rede urbana nos sertões de Minas Gerais, São Paulo e Goiás.

Apontamos também aspectos que, apesar de estarem presentes na historiografia sobre o período colonial, merecem atenção mais detida, como é o caso da presença quilombola na formação de diversos municípios do sudoeste de Minas Gerais, trazida à luz pela toponímia indicada na cartografia. Finalmente, acreditamos que as questões estão longe de uma resolução definitiva e que o estudo da documentação produzida pelos governos das capitanias e pelos bispados pode revelar novas frentes de investigação para pesquisadores interessados em compreender o cotidiano nos sertões e a complexidade do processo de urbanização. 


\section{REFERÊNCIAS}

FONTES MANUSCRITAS

AUTO de posse que tomou o Reverendo Vigário da Vara Francisco Bueno de Azevedo dos Barrancos e Itaupabas do Rio Pardo [...]. Arquivo da Cúria Metropolitana de São Paulo. Pasta Paroquial de Caconde, 20 de março de 1782, 1fl., avulso.

BATIZADOS de Caconde e do Sertão do Rio Pardo. 2 mar. 1775 - 1 out. 1840. Manuscrito digitalizado pelo Family Search International, 2014. Disponível em: <https://bit.ly/3silHge>. Acesso em: 2 abr. 2020.

CARTA Chorographica da Capitania de São Paulo em que mostra a verdadeira cituação do Logares por onde se Fizeram as sete principaes divizoens do seu governo com o de Minas Geraes. 1766. SI - 003(01). Mapa feito a nanquim, 49,5 × 63,0 cm. Disponível em: <https:// bit.ly/2UBqtaD>. Acesso em: 2 abr. 2020.

CARTA da Junta (da Administração e arrecadação da Fazenda Real da capitania de São Paulo) para (D. José I), dando-lhe conta dos desentendimentos entre as capitanias de Minas Gerais e de São Paulo por causa da posse de terras e descobrimentos [...]. 12 de janeiro de 1773. Arquivo Histórico Ultramarino. Cx. 28, doc. no 2618. AHU-ACL-N-Sao Paulo. No Catálogo: 2618. Colônia: São Paulo, localidade: São João de Jacui. Disponível em: <https://bit.ly/2O4nO8M>. Acesso em: 14 abr. 2020.

CARTA de posse do Descoberto de Nossa Senhora da Conceição do Rio Pardo. Nossa Senhora da Conceição: [s. n.], 2 out. 1765. Manuscrito da Biblioteca Nacional do Rio de Janeiro. Localizador: I-30,25,011. Disponível em: <http://bit.ly/2IWQzhz>. Acesso em: 16 mar. 2020.

CARTA Geográfica que compreende toda a comarca do Rio das Mortes, Villa Rica, da cidade de Mariana e do Governo de Minas Gerais. SI - 003(07). 62,7 × 41,5 cm. Disponível em: <https://bit.ly/2UUCgQg>. Acesso em: 31 mar. 2020.

LIVRO da Arquidiocese de São Paulo, nº 1, 1880-1905, localizador: 8-2-23, fl. 166f.

MAPPA da Capitania de S. Paulo em que se mostra tudo o que ella tinha antigamente the o Rio Paraná. [ca.1773]. 1 mapa ms.: color., desenho a nanquim; 53,5 × 41,3 cm em folha 56,5 $\times$ 44,2 cm. Disponível em: <http://bit.ly/3d20joy>. Acesso em: 14 mar. 2020.

PLANTA do novo descoberto de São João de Jacuí. [ca. 17--]. Escala [ca. 1:1.000.000]. - 1 carta ms.: color., desenho a nanquim; $61,9 \times 39 \mathrm{~cm}$ em folha $67,4 \times 44,4 \mathrm{~cm}$. Disponível em: $<$ https://bit.ly/3btLYzH>. Acesso em: 27 mar. 2020. 
RELLAÇÃO das Marchas que se seguirão na Deligencia da Mostra geral, que se principiou em 13 de Agosto de 1764, e seacabou em 3 de Dezembro do dito anno, com declaração da Cidade, Villas, e mais partes porque setranzitou p. ${ }^{\mathrm{a}}$ od. ${ }^{\circ}$ feito, e outras Deligencias do Real Serviço. Feita a 22 de Janeiro de 1765. APM, AHU-ConUltra-Brasil-MG-Cx. 84, Doc 34.

ROCHA, José Joaquim da. Mapa da Capitania de Minas Gerais com a divisa de suas Comarcas. 1778. APM - 085(01). Mapa, 46,5 × 39,0 cm. Disponível em: <https://bit.ly/2xdv3mE > Acesso em: 8 abr. 2020.

ROCHA, José Joaquim da. Mappa da Comarca do Rio das Mortes, pertencente a Capitania das Minas Gerais: que mandou descrever o Ilustrissimo e Excelentissimo Senhor D. Antonio de Noronha Governador e Cap. am General da mesma Capitania segundo as mais exactas informaçõens. 1777. 1 mapa ms., desenho a tinta, $50 \times 59,5 \mathrm{~cm}$ em f. $56 \times 66$. Disponível em: $<$ http://bit.ly/2RUCSFt>. Acesso em: 19 maio 2020.

ROCHA, José Joaquim da. Mostrace neste mapa o julgado das cabeceiras do rio das Velhas e a parte da Capitania de Minas Gerais: com a devisa de ambas as capitanias dado pela Capitan José Manoel. 1796. 1 mapa ms., desenho a tinta ferrogálica, 49,8 × 42,5cm em f. 52,8 × 47 . Disponível em: <https://bit.ly/2UCQcQd>. Acesso em: 14 abr. 2020.

SÃO PAUlO (Estado). Comissão Central de Estatística. Relatorio apresentado ao Exm. Sr. Presidente da Provincia de São Paulo - 1888. São Paulo: Leroy King Bookwalter; Typographia King, 1888. 578 p. Disponível em: <https://bit.ly/34jxbpC>. Acesso em: 3 out. 2020.

FONTES IMPRESSAS

ANAIS DA BIBLIOTECA NACIONAL, Rio de Janeiro, v. 108, 1988. Disponível em: <https://bit. ly/2z1EaaH>. Acesso em: 18 mar. 2020.

ARQUIVO PÚBLICO DO ESTADO DE SÃO PAULO. Documentos interessantes para a história e costumes de São Paulo. Divisas de São Paulo e Minas Gerais. v. XI. São Paulo: Typografia Espindola Siqueira e Comp., 1896.

ARQUIVO PÚBLICO DO ESTADO DE SÃO PAULO. Documentos interessantes para a história e costumes de São Paulo. Offíccios do Capitão General D. Luiz Antônio de Souza Botelho Mourão aos diversos funcionários da Capitania, 1772-1775. v. LXIV. São Paulo: Typographia do Globo, 1939. Disponível em: <https://bit.ly/2wnIIXO>. Acesso em: 8 abr. 2020.

BLUTEAU, Rafael. Vocabulario portuguez, e latino, aulico, anatomico, architectonico, bellico, botanico...: autorizado com exemplos dos melhores escritores portuguezes, e latinos; e offerecido a El Rey de Portugal D. Joaõ V. Coimbra, Collegio das Artes da Companhia de Jesus. Lisboa: Officina de Pascoal da Sylva, 1712-1728. 8 v. (2 suplementos). Disponível em: <http:// bit.ly/3ueO6po>. Acesso em: 2 abr. 2020. 
INSTITUTO ESTADUAL DO PATRIMÔNIO HISTÓRICO E ARTÍSTICO DE MINAS GERAIS. Guia de bens tombados do Iepha-MG. 2. ed. Belo Horizonte: Iepha, 2014. v. 1: il. Disponível em: <https://bit.ly/3eldwd6>. Acesso em: 14 abr. 2020.

INSTITUTO HISTÓRICO E GEOGRÁFICO DE SÃO PAULO. Relação geral da Diocese de São Paulo, pelo Bispo. D. Manoel da Ressurreição. Revista do Instituto Histórico e Geográfico de São Paulo, São Paulo, v. IV, 1898-1899. Disponível em: <https://bit.ly/2yLOVOf>. Acesso em: 8 abr. 2020.

MAPA Político da Região Sudeste. Rio de Janeiro: IBGE, 2009. 1mapa, color. Escala 1:1.800.000. Projeção policônica. Disponível em: <https://bit.ly/2NLKHxI>. Acesso em: 26 fev. de 2021.

SILVA, Antonio de Morais; BLUTEAU, Rafael. Diccionario da lingua portugueza composto pelo padre D. Rafael Bluteau, reformado, e accrescentado por Antonio de Moraes Silva natural do Rio de Janeiro. Lisboa: Simão Tadeu Ferreira, 1789. 2 v.: v. 1: xxii, 752 p.; v. 2: 541 p. Disponível em: <https://bit.ly/3h7hkyW>. Acesso em: 8 abr. 2020.

LIVROS, ARTIGOS E TESES

ALMEIDA, Carolina Farnetani de. A rede urbana a oeste do rio Sapucaí em meados do século XVIII até 1833: conflito entre as capitanias, províncias e bispados de Minas Gerais e São Paulo. 2019. Dissertação (Mestrado em Urbanismo) - Pontifícia Universidade Católica de Campinas, Campinas, 2019. Disponível em: <https://bit.ly/3c1TZf5>. Acesso em: 26 maio 2020.

ALMEIDA, Carolina Farnetani de; PEREIRA, Renata Baesso. A rede urbana no oeste do rio Sapucaí: Cabo Verde: arraial, freguesia e vila. Urbana, Campinas, v. 10, n. 1, p. 131-159, 2018. Disponível em: <https://bit.ly/3a2D8rK>. Acesso em: 14 abr. 2020.

AMANTINO, Marcia. As guerras justas e a escravidão indígena em Minas Gerais nos séculos XVIII e XIX. Varia Historia, Belo Horizonte, v. 22, n. 35, p. 189-206, 2006. Disponível em: $<$ https://bit.ly/34BWe6K>. Acesso em: 14 jan. 2020.

AMANTINO, Marcia. O mundo das feras: os moradores do sertão oeste de Minas Gerais: século XVIII. 2001. Tese (Doutorado em História) - Instituto de Filosofia e Ciências Sociais, Universidade Federal do Rio de Janeiro, Rio de Janeiro, 2001.

AMANTINO, Marcia. O sertão oeste em Minas Gerais: um espaço rebelde. Varia Historia, Belo Horizonte, v. 19, n. 29, p. 79-97, 2003. Disponível em: <https://bit.ly/2KaKBu5>. Acesso em: 14 abr. 2020.

AMANTINO, Marcia. Sertões, índios e quilombolas. Revista do Arquivo Público Mineiro, Belo Horizonte, v. 50, n. 1, p. 92-109, 2014. Disponível em: <https://bit.ly/2wFA2ML>. Acesso em: 14 abr. 2020. 
ANDRADE, Francisco Eduardo de. A conversão do sertão capelas e a governamentalidade nas Minas Gerais. Varia Historia, v. 23, n. 37, p. 151-166, 2007. Disponível em: <https://bit. ly/34zlQRM>. Acesso em: 14 abr. 2020.

ANDRADE, Francisco Eduardo de. Fronteira e instituição de capelas nas Minas: América portuguesa. América Latina en la Historia Económica, México, n. 35, p. 271-296, 2011. Disponível em: <https://bit.ly/3elNVRc>. Acesso em: 9 jan. 2020.

ANDRADE, Francisco Eduardo de. Poder e capelania na fronteira das Minas Gerais: o sertão do oeste. In: CONGRESSO INTERNACIONAL ESPAÇO ATLÂNTICO DE ANTIGO REGIME: PODERES E SOCIEDADES, 2005, Lisboa. Anais [...]. Lisboa: Instituto Camões, 2008. p. 218-220.

ARRAES, Damião Esdras Araújo. Ecos de um suposto silêncio: paisagem e urbanização dos "certoens" do Norte, c.I666-I820. 2017. Tese (Doutorado em Arquitetura e Urbanismo) Faculdade de Arquitetura e Urbanismo, Universidade de São Paulo, São Paulo, 2017. Disponível em: <https://bit.ly/2A9YA1E>. Acesso em: 14 abr. 2020.

ARRAES, Esdras. Plantar povoações no território: (re)construindo a urbanização da capitania do Piauí, 1697-1761. Anais do Museu Paulista, São Paulo, v. 24, n. 1, p. 257-298, 2016. Disponível em: <http://bit.ly/2OiVwoc>. Acesso em: 1 fev. 2020.

BACELLAR, Carlos de Almeida Prado. Os senhores da terra: família e sistema sucessório de engenho no oeste paulista, 1765-1855. Campinas: Centro de Memória: Unicamp, 1997.

BACELLAR, Carlos de Almeida Prado; BRIOSCHI, Lucila Reis. Na estrada do Anhanguera: uma visão regional da história paulista. São Paulo: Humanitas, 1999.

BARBOSA, Waldemar de Almeida. Dicionário bistórico-geográfico de Minas Gerais. Belo Horizonte: Promoção da Família, 1971.

BELLOTTO, Heloísa Liberalli. Autoridade e conflito no Brasil colonial: o governo do Morgado de Mateus em São Paulo (1765-1775). São Paulo: Alameda, 2007.

BRIOSCHI, Lucila Reis. Criando história: paulistas e mineiros no nordeste de São Paulo, 17251835. 1995. Tese (Doutorado em Sociologia) - Faculdade de Filosofia, Letras e Ciências Humanas, Universidade de São Paulo, São Paulo, 1995.

BUENO, Beatriz Piccolotto Siqueira. Dilatação dos confins: caminhos, vilas e cidades na formação da Capitania de São Paulo (1532-1822). Anais do Museu Paulista, São Paulo, v. 17, n. 2, p. 251-294, 2009. Disponível em: <https://bit.ly/34yTpDJ>. Acesso em: 30 jan. 2020.

BUENO, Beatriz Piccolotto Siqueira. Introdução. Anais do Museu Paulista, São Paulo, v. 20, n. 1, p. 11-40, 2012. Disponível em: <https://bit.ly/2HRmUcs>. Acesso em: 5 out. 2020. 
BUENO, Beatriz Piccolotto Siqueira. O brasil-colônia: em que medida mais urbano do que parece à primeira vista? In: CONGRESO IBEROAMERICANO DE HISTORIA URBANA, 1., 2016, Santiago de Chile. Anais [...]. Campinas: Aihu, 2016. p. 825-834. Disponível em: <https://bit. ly/2RFtgOl>. Acesso em: 14 abr. 2020.

BUENO, Beatriz Piccolotto Siqueira. Por uma arqueologia da paisagem: mobilidade e enraizamento em perspectiva americana. Labor e Engenho, Campinas, v. 11, n. 3, p. 242-262, 2017. Disponível em: <https://bit.ly/2TBmpps>. Acesso em: 30 out. 2020.

CAMARGO, Monsenhor Florêncio da Silveira. A Igreja na bistória de São Paulo (1530-1624). São Paulo: Instituto Paulista de História e Arte Religiosa, 1952. v. 4.

CAMPANHOlE, Adriano. Memória da cidade de Caconde: freguesia antiga de N. S. da Conseyção do Bom Sucesso do Rio Pardo. São Paulo: Latina, 1979.

CARRARA, Angelo Alves. Antes das Minas Gerais: conquista e ocupação dos sertões mineiros. Varia Historia, Belo Horizonte, v. 23, n. 38, p. 574-596, 2007. Disponível em: <https://bit. ly/34BCuQH>. Acesso em: 14 jan. 2020.

CARVAlHO, Adilson de. A Freguesia de Nossa Senbora da Assumpção do Cabo Verde e sua bistória. Cabo Verde: Gráfica Jundiaí, 1998.

CRUZ, Cícero Ferraz. Cidade difusa: a construção do território na Vila de Campanha e seu termo, séculos XVIII-XIX. 2016. Tese (Doutorado em Arquitetura e Urbanismo) - Faculdade de Arquitetura e Urbanismo, Universidade de São Paulo, São Paulo, 2016.

CRUZ, Cícero Ferraz. Fazendas do sul de Minas. Brasília, DF: Iphan, 2010.

DELSON, Roberta Marx. Novas vilas para o Brasil-colônia: planejamento espacial e social no século XVIII. Brasília, DF: Alva-Ciord, 1997.

DERNTL, Maria Fernanda. Método e arte: criação urbana e organização territorial na capitania de São Paulo, 1765-1811. 2010. Tese (Doutorado em Arquitetura e Urbanismo) - Faculdade de Arquitetura e Urbanismo, Universidade de São Paulo, São Paulo, 2010. Disponível em: <https://bit.ly/2V64r02>. Acesso em: 14 abr. 2020.

DERNTL, Maria Fernanda. Método e arte: urbanização e formação territorial na capitania de São Paulo, 1765-1811. São Paulo: Alameda, 2013.

DERNTL, Maria Fernanda. Uma oficina de novidades: a implantação de núcleos urbanos na capitania de São Paulo, 1765-1775. Anais do Museu Paulista, São Paulo, v. 20, n. 1, p. 109-131, 2012. Disponível em: <https://bit.ly/36s3CEI>. Acesso em: 2 out. 2020. 
DINIZ, Nathália Maria Montenegro. Um sertão entre tantos outros: fazendas de gado das Ribeiras do Norte. 2013. Tese (Doutorado em Arquitetura e Urbanismo) - Faculdade de Arquitetura e Urbanismo, Universidade de São Paulo, São Paulo, 2013. Disponível em: <https:// bit.ly/3emSkm8>. Acesso em: 14 abr. 2020.

DINIZ, Nathália. Um sertão entre tantos outros. São Paulo: Versal, 2015.

FERREIRA, Rafael Augusto Silva. Entre fronteiras e conflitos: aspectos fundiários da formação do Sertão do Rio Pardo, 1775-1865. 2017. Dissertação (Mestrado em Urbanismo) - Pontifícia Universidade Católica de Campinas, Campinas, 2017. Disponível em: <https://bit. ly/2XyOUay>. Acesso em: 14 abr. 2020.

FERREIRA, Rafael Augusto Silva; PEREIRA, Renata Baesso. Formação territorial enquanto instrumento de afirmação das fronteiras entre São Paulo e Minas Gerais nos séculos XVIII e XIX: a Freguesia de N. S. da Conceição do Bom Sucesso do Rio Pardo. Labor e Engenbo, Campinas, v. 11, n. 3, p. 313, 2017. Disponível em: <https://bit.ly/34yVbEQ>. Acesso em: 14 abr. 2020.

FERREIRA, Rafael Augusto Silva; PEREIRA, Renata Baesso; ALMEIDA, Carolina Farnetani de. Nos sertões do Rio Grande: disputas entre capitanias e bispados na ocupação da hinterlândia. In: CONGRESSO IBERO-AMERICANO DE HISTÓRIA URBANA, 2., 2019, México. Anais [...]. Campinas: Aihu, 2019. p. 2699-2711. Disponível em: <https://bit.ly/39fu7ev>. Acesso em: 14 abr. 2020.

FLORENTINO, Manolo; AMANTINO, Marcia. Uma morfologia dos quilombos nas Américas, séculos XVI-XIX. História, Ciências, Saúde-Manguinbos, Rio de Janeiro, v. 19, n. 1, p. 259-297, 2012. Disponível em: <https://bit.ly/2XDf0t4>. Acesso em: 21 jan. 2020.

FONSECA, Cláudia Damasceno. Arraiais e vilas d'el rei: espaço e poder nas Minas setecentistas. Belo Horizonte: Editora UFMG, 2011a.

FONSECA, Cláudia Damasceno. Pouvoirs, villes e territoires: gênese et représentations des espaçes urbains le Minas Gerais (Brésil, XVIIIe - debut du XIXe siècle). 2001. Tese (Doutorado em História) - École des Hautes Études en Sciences Sociales, Paris, 2001.

FRIDMAN, Fania. Breve história do debate sobre a cidade colonial brasileira. In: OLIVEIRA, Fabricio Leal de; LIMA JUNIOR, Pedro de Novais (orgs.). Território e planejamento: perspectivas transdisciplinares. Rio de Janeiro: Letra Capital, 2011. p. 499-522.

FURTADO, Júnia Ferreira. Um cartógrafo rebelde? José Joaquim da Rocha e a cartografia de Minas Gerais. Anais do Museu Paulista, São Paulo, v. 17, n. 2, p. 155-187, 2009. Disponível em: <https://bit.ly/2V9zcB7>. Acesso em: 30 jan. 2020.

GOUVÊA, Maria de Fátima Silva. Poder político e administração na formação do complexo atlântico português (1645-1808). In: FRAGOSO, João; BICALHO, Maria Fernanda; GOUVÊA, Maria de Fátima Silva (orgs.). O Antigo Regime nos trópicos: a dinâmica imperial portuguesa (séculos XVI-XVIII). Rio de Janeiro: Civilização Brasileira, 2001. p. 286-315. 
GUIMARÃES, Carlos Magno. Os quilombos do século do ouro. Varia Historia, Belo Horizonte, v. 4, n. 6, p. 15-45, 1988. Disponível em: <https://bit.ly/2Vrf24M>. Acesso em: 14 abr. 2020.

HESPANHA, António Manuel. A constituição do Império português. Revisão de alguns enviesamentos correntes. In: FRAGOSO, João; BICALHO, Maria Fernanda; GOUVÊA, Maria de Fátima Silva (orgs.). O Antigo Regime nos trópicos: a dinâmica imperial portuguesa (séculos XVI-XVIII). Rio de Janeiro: Civilização Brasileira, 2001. p. 165-188.

HESPANHA, António Manuel. Caleidoscópio do Antigo Regime. São Paulo: Alameda, 2012.

KANTOR, Iris. Cartografia e diplomacia: usos geopolíticos da informação toponímica (17501850). Anais do Museu Paulista, São Paulo, v. 17, n. 2, p. 39-61, 2009. Disponível em: https:// bit.ly/2Vbd75s. Acesso em: 16 fev. 2020.

LOURENÇO, Luís Augusto Bustamante. A oeste das minas: escravos, índios e homens livres numa fronteira oitocentista Triângulo Mineiro (1750-1861). Uberlândia: Edufu, 2005.

LUSTOSA, Oscar de Figueiredo. Situação religiosa da capitania de São Paulo na palavra de seu bispo, D. Frei Manuel da Ressureição (1777). Revista de História, São Paulo, v. 52, n. 104, p. 909-924, 1975. Disponível em: <https://bit.ly/3chECzN>. Acesso em: 14 abr. 2020.

MANO, Marcel. Índios e negros nos sertões das minas: contatos e identidades. Varia Historia, Belo Horizonte, v. 31, n. 56, p. 511-546, 2015. Disponível em: <https://bit.ly/3cm22nU>. Acesso em: 13 jan. 2020.

MARTINS, Tarcísio José. Quilombo do Campo Grande: história de Minas que se devolve ao povo. Contagem: Santa Clara, 2008.

MOURA, Nádia Mendes de. Sertões de mar a mar: Goyazes em suas filigranas (c. 1726-1830). 2018. Tese (Doutorado em Arquitetura e Urbanismo) - Faculdade de Arquitetura e Urbanismo, Universidade de São Paulo, São Paulo, 2018. Disponível em: <https://bit. ly/2V9CG6Y>. Acesso em: 14 abr. 2020.

PEREIRA, Renata Baesso; FERREIRA, Rafael Augusto Silva. Entre o rural e o urbano: aspectos fundiários na formação de patrimônios religiosos na Freguesia de Caconde, SP, séculos XVIII e XIX. In: SEMINÁRIO DE HISTÓRIA DA CIDADE E DO URBANISMO, 15., 2018, Rio de Janeiro. Anais [...]. Rio de Janeiro: UFRJ, 2018. p. 1-22. Disponível em: <https://bit. ly/3chHyfL>. Acesso em: 14 abr. 2020.

PICCINATO JUNIOR, Dirceu. Terra urbana, patrimônio fundiário: uma análise histórica da apropriação do solo na configuração do urbano no nordeste paulista (1800-1930). 2012. Dissertação (Mestrado em Urbanismo) - Pontifícia Universidade Católica de Campinas, Campinas, 2012. Disponível em: <https://bit.ly/36yrPYb>. Acesso em: 26 maio 2020. 
POLITO, Jéssica de Almeida. Territórios de civilidade: o papel das Mogis na formação e reestruturação do leste paulista, século XVII-XIX. 2013. Dissertação (Mestrado em Urbanismo) - Pontifícia Universidade Católica de Campinas, Campinas, 2013. Disponível em: <http://bit. ly/3pCeje2>. Acesso em: 14 abr. 2020.

REIS FILHO, Nestor Goulart. Contribuição ao estudo da evolução urbana do Brasil (15001720). São Paulo: Pioneira, 1968.

REIS FILHO, Nestor Goulart. O caminho do Anhanguera. São Paulo: Via das Artes, 2014.

ROCHA, José Joaquim da. Geografia histórica da Capitania de Minas Gerais: descrição geográfica, topográfica, histórica e política da Capitania de Minas Gerais. Belo Horizonte: Fundação João Pinheiro, 1995.

SALGADO, Ivone; PEREIRA, Renata Baesso. A formação da rede urbana como estratégia de definição da fronteira entre as capitanias de Minas Gerais e de São Paulo na segunda metade do século XVIII. Labor e Engenho, Campinas, v. 11, n. 3, p. 218-241, 2017a. Disponível em: <https://bit.ly/2XxCKPn>. Acesso em: 14 abr. 2020.

SALGADO, Ivone; PEREIRA, Renata Baesso. A formação de núcleos urbanos no Brasil colônia: procedimentos para elevar freguesias a vilas na Capitania de São Paulo na segunda metade do século XVIII. Paranoá, Brasília, DF, v. 18, n. 18, p. 1-21, 2017b. Disponível em: <https:// bit.ly/2xxFotR>. Acesso em: 14 abr. 2020.

SANTOS, Milton. A natureza do espaço: técnica e tempo, razão e emoção. São Paulo: Edusp, 2002.

SANTOS, Milton. Por uma geografia nova: da crítica da geografia a uma geografia crítica. 6. ed. São Paulo: Edusp, 2004.

SENNA, Nelson de. Nótulas sobre a toponymia geographica (de origem brasilico-americana ou indigena e de brasilico-africana) em Minas Geraes. Revista do Arquivo Público Mineiro, Belo Horizonte, v. 25, n. 1, p. 273-286, 1937. Disponível em: <https://bit.ly/2XgudQL>. Acesso em: 14 abr. 2020.

SENNA, Nelson de. Toponymia geographica de origem brasilico-indígena em Minas Gerais. Revista do Arquivo Público Mineiro, Belo Horizonte, v. 20, p. 191-337, 1924. Disponível em: <https://bit.ly/2X44HO4>. Acesso em: 26 abr. 2020.

SOUZA, Laura de Mello e. O sol e a sombra: política e administração na América portuguesa do século XVIII. São Paulo: Companhia das Letras, 2006. 
<https://www.bbm.usp.br>. Acesso em: 18 mar. 2020.

$<$ http://www.bndigital.bn.gov.br/acervodigital/>. Acesso em: 18 mar. 2020.

<http://www.siaapm.cultura.mg.gov.br/>. Acesso em: 18 mar. 2020.

$<$ http://acervo.redememoria.bn.br/>. Acesso em: 27 mar. 2020.

<http://www.cmd.unb.br/resgate_index.php>. Acesso em: 14 abr. 2020.

<http://www.familysearch.org>. Acesso em: 2 abr. 2020.

Artigo apresentado em: 17/7/2020. Aprovado em: 8/12/2020.

\section{(cc) BY}

